\title{
MEMBERS OF THE FAMILY
}

\section{CAMPYLOBACTERACEAE:}

\section{CAMPYLOBACTER JEJUNI, CAMPYLOBACTER COLI}

\section{Tarja Pitkanen}

National Institute of Health and Welfare

Kuopio, Finland

\section{Marja-Liisa Hanninen}

University of Helsinki

Helsinki, Finland 


\section{Copyright:}

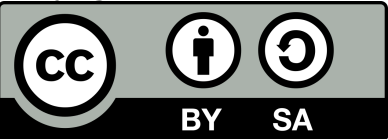

This publication is available in Open Access under the Attribution-ShareAlike 3.0 IGO (CC-BY-SA 3.0 IGO) license (http://creativecommons.org/licenses/by-sa/3.0/igo). By using the content of this publication, the users accept to be bound by the terms of use of the UNESCO Open Access Repository (http://www.unesco.org/openaccess/terms-use-ccbysa-en).

\section{Disclaimer:}

The designations employed and the presentation of material throughout this publication do not imply the expression of any opinion whatsoever on the part of UNESCO concerning the legal status of any country, territory, city or area or of its authorities, or concerning the delimitation of its frontiers or boundaries. The ideas and opinions expressed in this publication are those of the authors; they are not necessarily those of UNESCO and do not commit the Organization.

\section{Citation:}

Pitkanen, T. and Hanninen, M-L. (2017). Members of the family Campylobacteraceae: Campylobacter jejuni, Campylobacter coli. In: J.B. Rose and B. Jiménez-Cisneros, (eds) Water and Sanitation for the 21st Century: Health and Microbiological Aspects of Excreta and Wastewater Management (Global Water Pathogen Project). ( A. Pruden, N. Ashbolt and J. Miller (eds), Part 3: Specific Excreted Pathogens:

Environmental and Epidemiology Aspects - Section 2: Bacteria), Michigan State University, E. Lansing, MI, UNESCO. https://doi.org/10.14321/waterpathogens.23

Acknowledgements: K.R.L. Young, Project Design editor; Website Design: Agroknow (http://www.agroknow.com)

Last published: July 31, 2017 


\section{Summary}

Campylobacter infection is one the most widely spread bacterial gastroenteric disease worldwide. The global estimate of the burden of campylobacteriosis for 2010 was 7.5 million disability-adjusted life years (DALYs). The knowledge of the incidence, prevalence, clinical output and epidemiology of Campylobacter as a common cause of human acute gastroenteritis has been published since 1977, but the coverage of prevalence and incidence data from different parts of the world is still highly variable. In the industrialized countries, the number of reported cases has increased during the last 10 to 15 years. However, national statistics underestimate the actual population incidence because only a fraction of the Campylobacter cases present to health services, and many of these are not investigated further. In addition, co-infections with other enteric pathogens are common. In high-income regions, the most common symptoms of a Campylobacter infection include an acute, self-limiting gastroenteritis, with an incubation period of 2 to 5 days. In developing regions, watery diarrhea is the most common presentation of the illness, commonly seen during the first years of life. In the latter regions, due to the endemic nature and acquired immunity after the repeated exposure to Campylobacter, adults are only infrequently affected.

Currently, 29 species and 12 subspecies are classified in the genus Campylobacter. The most important Campylobacter species in human gastroenteritis is Campylobacter jejuni, which accounts for 90 to $95 \%$ of all campylobacteriosis cases reported. The majority of the remaining cases are caused by Campylobacter coli, but the importance of $C$. coli as an enteric pathogen varies between regions. The role of some other species (Campylobacter lari, Campylobacter upsaliensis, Campylobacter concisus) is less well characterized. Based on the data of experimental infections and indirectly from waterborne outbreaks, it is known that exposure to only a few hundred cells may result in illness. Due to uncertainties in estimating the doseresponse relation at the typically low doses from water exposures, risk estimations for $C$. jejuni exposures are highly uncertain, and in the absence of dose-response data for $C$. coli or other Campylobacter species, not directly possible.

A wide variety of animals, especially poultry, wild birds, cattle and sheep carry high numbers of $C$. jejuni and $C$. coli as commensals in their intestines, all being potential reservoirs. Fecal contamination of food, recreational water and drinking water contributes to human infections and the fecal material of infected persons (symptomatic and asymptomatic) spread the organisms back to environment through sewage plants and toilets. Reported Campylobacter numbers in non-disinfected wastewater effluents vary between 100 and 100,000 CFU/ L. Campylobacter are frequently isolated from surface waters from different parts of the world despite the fact that the isolation of Campylobacter from water requires specialized culturebased techniques and may fail due to insufficient method sensitivity or difficulties in separation of Campylobacter from the non-target bacteria. The potential false negative results due to the occurrence of viable-but-not-culturable Campylobacter and other difficult to culture situations has facilitated the development of nucleic acid-based molecular Campylobacter detection methods.

Mechanisms that enable Campylobacter to survive in the environment are poorly understood. Different survival characteristics and abilities of Campylobacter species under environmental conditions affect our understanding of Campylobacter ecology and diversity. For example, it has been reported that $C$. lari can survive better in aquatic environments than $C$. jejuni and $C$. coli. The survival of Campylobacter is favoured by low temperature, the absence of sunlight and by low numbers of indigenous microbiota. In general, it can be assumed that the same water purification techniques that are capable of removing Escherichia coli from water, remove or inactivate Campylobacter cells as efficiently. The exact Campylobacter removal rates, however, remain unknown due to the semi-quantitative nature of the Campylobacter detection methods.

\section{Campylobacter spp.}

\subsection{Epidemiology of the Disease and Pathogen(s)}

\subsection{Global Burden of Disease}

Campylobacteriosis is one the most common bacterial gastroenteric diseases worldwide (Blaser, 1997; Murray et al., 2012; Scallan et al., 2015). Most infections are sporadic and outbreaks are rather uncommon. Since, Skirrow (1977) published data showing $C$. jejuni was a much more common cause of human acute gastroenteritis than previously estimated, data on the incidence, prevalence and epidemiology has vastly improved, yet data is still highly variable. Most reliable data based on notification requirement of transmissible infectious diseases to public health authorities relates to developed countries where surveillance systems have been active for a long time (e.g. Member States of European Union, United States of America and Canada). On the other hand less detailed and unsystematic data production systems are available from developing regions that still provide useful data.

The global estimate of the burden of campylobacteriosis for 2010 was 7.5 million disability-adjusted life years (DALYs). This was a clear improvement from 1990, when the burden of campylobacteriosis was estimated to be 16.6 million DALYs. However, Campylobacter enteritis accounted for $8.5 \%$ of the total burden of diarrheal disease, ranking fourth after rotavirus, cryptosporidiosis and Escherichia coli diarrhea (combined enterotoxigenic and enteropathogenic E. coli infections) (Murray et al., 2012). Thus, Campylobacter remains one of the most frequently occurring bacterial causes of gastrointestinal diseases worldwide. Several countries have performed country-level analyses of DALYs. In the USA in 2006, 845,000 people were estimated to have acquired domestic Campylobacter infection and the estimated DALY was $22,500(10,400$ to 38,600; 90\% Credible Interval, population size approx. 325 
million). In this number the sequelae (IBD, GuillanBarre/Miller Fisher syndromes, and reactive arthritis) increased the years of life disabled (YLD) by more than $70 \%$ of the total DALY (Scallan et al., 2015). Further, in the Netherlands (population approx. 17 million; estimated number of cases 108,000 (33,000-271,000) Campylobacter DALY was estimated for 2011 to be 3,633 (Mangen et al., 2015). In Australia (population 22 million, Campylobacter cases 774,003) estimated DALY for 2010 was 18222 showing very high impact on public health (Gibney et al., 2014).

\subsubsection{Global Distribution}

An overview on global distribution of reported campylobacteriosis cases is presented in Table 1. The epidemiology and demography of Campylobacter infections differs between developing and industrialized countries. In developing countries, symptomatic disease is most commonly seen only during the first two years of life, and symptomatic illness in adults is rare due to the endemic nature of Campylobacter in these regions. The clinical picture also differs from that seen in industrialized countries, as watery diarrhea is the most common presentation. The peak in the very young and lack of clinical illness in adults is believed to be due to acquired immunity after repeated exposure to Campylobacter, and supporting this a high percentage of asymptomatic seropositive individuals have been reported in several studies (Blaser, 1997; Kirkpatrick and Tribble, 2011; PlattsMills et al., 2015). In addition, co-infection with other enteric pathogens is relatively common. In developing countries monitoring data is poorly available. In a recent, prospective, multi-center, case-control study of acute moderate severe diarrhea in children (Enterics MultiCenter Study, GEMS), using culture based techniques Campylobacter spp. were found to be in the top five causes in Bangladesh, Pakistan and India among 2 to 5 year olds (Kotloff et al., 2013; Platts-Mills et al., 2015).

Table 1. Incidence of diagnosed Campylobacteriosis disease

\begin{tabular}{|c|c|c|c|c|}
\hline Area & Study Period & Patient Age & Incidence (Annual)/ Unless Otherwise Noted & Reference \\
\hline Australia & 2010 & All ages & $\begin{array}{c}0.11 \%^{\mathrm{a}} \\
(112.3 / 100,000)\end{array}$ & $\begin{array}{l}\text { NNDSS, } \\
2012\end{array}$ \\
\hline Bolivia & NR & NR & $\begin{array}{l}\text { Prevalence: } \\
10.5 \% \text { in diarrhea and } 9.6 \% \text { in asymptomatic persons }\end{array}$ & $\begin{array}{l}\text { Fernández, } \\
2011\end{array}$ \\
\hline Canada & 2006 & All ages & $\begin{array}{c}0.45 \%^{\mathrm{b}} \\
(447.2 / 100,000) \\
(\text { estimated })\end{array}$ & $\begin{array}{l}\text { Thomas et } \\
\text { al., } 2013\end{array}$ \\
\hline Chile & NR & NR & $\begin{array}{c}\text { Prevalence: } \\
9.2 \text { to } 14.1 \% \text { of gastroenteritis }\end{array}$ & $\begin{array}{l}\text { Fernández, } \\
2011\end{array}$ \\
\hline $\begin{array}{l}\text { Czech } \\
\text { Republic }\end{array}$ & 2014 & $\begin{array}{l}\text { All age } \\
\text { groups }\end{array}$ & $\begin{array}{c}0.20 \% \\
(197.4 / 100,000)\end{array}$ & $\begin{array}{l}\text { EFSA, } \\
2015\end{array}$ \\
\hline Denmark & 2014 & $\begin{array}{l}\text { All age } \\
\text { groups }\end{array}$ & $\begin{array}{l}0.07 \%{ }^{\mathrm{c}} \\
(67 / 100,000)\end{array}$ & $\begin{array}{l}\text { EFSA, } \\
2015\end{array}$ \\
\hline Finland & 2014 & $\begin{array}{l}\text { All age } \\
\text { groups }\end{array}$ & $\begin{array}{c}0.09 \%^{\mathrm{c}} \\
(89.7 / 100,000)\end{array}$ & $\begin{array}{l}\text { EFSA, } \\
2015\end{array}$ \\
\hline France & 2014 & $\begin{array}{l}\text { All age } \\
\text { groups }\end{array}$ & $\begin{array}{c}0.05 \% \\
(45.2 / 100,000)\end{array}$ & $\begin{array}{l}\text { EFSA, } \\
2015\end{array}$ \\
\hline \multirow[t]{2}{*}{ Guatemala } & \multirow[t]{2}{*}{2008 to 2012} & $\begin{array}{l}\text { Children }(< \\
5 \mathrm{y})\end{array}$ & $\begin{array}{c}0.19 \text { to } 1.29 \% \\
(185.5 \text { to } 1288.8 / 100,000)\end{array}$ & \multirow{2}{*}{$\begin{array}{l}\text { Benoit et } \\
\text { al., } 2014\end{array}$} \\
\hline & & $\begin{array}{l}\text { Other age } \\
\text { groups }\end{array}$ & $\begin{array}{c}0.09 \text { to } 0.22 \% \\
(92.5 \text { to } 215.8 / 100,000)\end{array}$ & \\
\hline $\begin{array}{l}\text { Japan } \\
\text { (Miuagi } \\
\text { Prefecture) }\end{array}$ & 2005 & $\begin{array}{l}\text { All age } \\
\text { groups }\end{array}$ & $\begin{array}{c}1.51 \% \\
(1,512 / 100,000)\end{array}$ & $\begin{array}{l}\text { Kubota et } \\
\text { al., } 2011\end{array}$ \\
\hline Kenya & 1997 to 2003 & NR & $7 \%$ & $\begin{array}{l}\text { Brooks et } \\
\text { al., } 2006\end{array}$ \\
\hline \multirow{2}{*}{$\begin{array}{l}\text { New } \\
\text { Zealand }\end{array}$} & 2003 & & $\begin{array}{c}0.40 \%^{\mathrm{d}} \\
(396 / 100,000)\end{array}$ & \multirow{2}{*}{$\begin{array}{l}\text { Lane and } \\
\text { Briggs, } \\
2014\end{array}$} \\
\hline & 2012 & All ages & $\begin{array}{c}0.16 \% \\
(159 / 100,000)\end{array}$ & \\
\hline Peru & NR & NR & $\begin{array}{c}\text { Prevalence: } \\
15 \text { to } 23 \% \text { of gastroenteritis }\end{array}$ & $\begin{array}{l}\text { Fernández, } \\
2011\end{array}$ \\
\hline Poland & 2014 & NR & $\begin{array}{c}0.0017 \% \\
(1.7 / 100,000)\end{array}$ & $\begin{array}{l}\text { EFSA, } \\
2015\end{array}$ \\
\hline
\end{tabular}




\begin{tabular}{|c|c|c|c|c|}
\hline Area & Study Period & Patient Age & Incidence (Annual)/ Unless Otherwise Noted & Reference \\
\hline Romania & 2014 & NR & $\begin{array}{c}0.0011 \% \\
(1.1 / 100,000)\end{array}$ & $\begin{array}{l}\text { EFSA, } \\
2015\end{array}$ \\
\hline Sweden & 2014 & $\begin{array}{l}\text { All age } \\
\text { groups }\end{array}$ & $\begin{array}{c}0.09 \%^{\mathrm{c}} \\
(85.9 / 100,000)\end{array}$ & $\begin{array}{c}\text { EFSA, } \\
2015\end{array}$ \\
\hline Tanzania & 2012 to 2013 & $\begin{array}{l}\text { Children }(< \\
5 \mathrm{y})\end{array}$ & $\begin{array}{l}\text { Prevalence: } \\
9.7 \%\end{array}$ & $\begin{array}{l}\text { Deogratias } \\
\text { et al., } 2014\end{array}$ \\
\hline Thailand & 1992 & $\begin{array}{l}\text { Children }(< \\
5 \mathrm{y})\end{array}$ & $\begin{array}{l}\text { Prevalence: } \\
15 \% \text { diarrheal patients }\end{array}$ & $\begin{array}{l}\text { Taylor et } \\
\text { al., } 1993\end{array}$ \\
\hline $\begin{array}{l}\text { The } \\
\text { Netherlands }\end{array}$ & 2014 & $\begin{array}{l}\text { All age } \\
\text { groups }\end{array}$ & $\begin{array}{c}0.05 \%^{\mathrm{e}} \\
(47.5 / 100,000)\end{array}$ & $\begin{array}{c}\text { EFSA, } \\
2015\end{array}$ \\
\hline $\begin{array}{l}\text { United } \\
\text { Kingdom }\end{array}$ & 2014 & $\begin{array}{l}\text { All age } \\
\text { groups }\end{array}$ & $\begin{array}{c}0.10 \%{ }^{\mathrm{f}} \\
(104 / 100,000)\end{array}$ & $\begin{array}{l}\text { EFSA, } \\
2015\end{array}$ \\
\hline \multirow{4}{*}{ USA } & \multirow{4}{*}{2014} & All ages & $\begin{array}{c}0.01 \%^{\mathrm{c}} \\
(13.3 / 100,000)\end{array}$ & \multirow{4}{*}{ CDC, 2014} \\
\hline & & $<5$ & $\begin{array}{c}0.02 \% \\
(22 / 100,000)\end{array}$ & \\
\hline & & 5 to 9 & $\begin{array}{c}0.01 \% \\
(9 / 100,000)\end{array}$ & \\
\hline & & 60 to 69 & $\begin{array}{c}0.02 \% \\
(15 / 100,000)\end{array}$ & \\
\hline
\end{tabular}

NR: Not Reported

${ }^{\mathrm{a}}$ No clear seasonality; ${ }^{\mathrm{b}}$ Seasonal peak in summer; ${ }^{\mathrm{c}}$ Peak in June to August; ${ }^{\mathrm{d}}$ Seasonal peak: January; ${ }^{\mathrm{e}}$ Peak in August; ${ }^{\mathrm{f}}$ Peak in May to June.

Most countries in Europe and North America have existing annual reporting and notification systems for incidence/prevalence of campylobacteriosis indicating that reliable data on prevalence of the infections among populations exists as well as trends of infections during longer periods of time are available. These trend data from Europe and North America have shown that the number of reported cases has increased during the last 10 to 15 years (EFSA, 2015; MMWR, 2014; Thomas et al., 2013). The data collection also includes information on the prevalence of $C$. jejuni and $C$. coli in their domestic animal reservoirs and certain foods improving assessment of potential sources of human infections. Some countries also have data on foreign travel-associated cases separated from those acquired from domestic sources (EFSA, 2015; Nichols et al., 2012; Kendall et al., 2012). This travel-associated data is important for targeting potential interpretation measures to decrease health burden of the illness. The incidence/prevalence data available from low-income countries is often lacking or fragmented but data collected from different sources indicate that the epidemiology of campylobacteriosis is different than in developed regions (Kotloff et al., 2013; Mason et al., 2013).

The European Union (EU) notification rate of campylobacteriosis was 64.8 per 100,000 population in 2013, but varied considerably between the member states (MS); from <2 to 173.7 per 100,000 population in Latvia and Czech Republic, respectively (Table 1), indicating the surveillance is not similarly developed within the EU countries. However, the true incidence of Campylobacter infection is higher than reported. The national statistics grossly underestimate the actual population incidence because only a fraction of the campylobacteriosis cases are presented to health services, and many of these are not investigated further. For instance in the UK, Tam et al. (2012) reported that every campylobacteriosis case reported to the national surveillance represented 9.3 community campylobacteriosis cases between 2008 and 2009. Overall, the true incidence is expected to range between 4.4 and 9.3 per 1,000 person-years population in high-income countries. The underreporting level varies between countries depending on functionality of the surveillance system.

\subsubsection{Symptomatology}

The most important Campylobacter species in human gastroenteritis is Campylobacter jejuni, which accounts for 90 to $95 \%$ of all campylobacteriosis cases identified. The majority of the remaining cases are caused by Campylobacter coli, but the importance of $C$. coli as an enteric pathogen varies between regions, degree of urbanization and age of the patient suggesting that the epidemiology of $C$. coli infection differs among countries (Blaser, 1997). However, the predominance of $C$. jejuni and $C$. coli may be biased by the selective cultivation media employed (Lastovica and Allos, 2008). The role of some other species (Campylobacter fetus, Campylobacter lari, Campylobacter upsaliensis, Campylobacter concisus) is less well characterized, especially their role in infections in 
developing countries.

In high-income regions, the most common symptoms of a Campylobacter infection include an acute, self-limiting gastroenteritis, and the incubation period is typically 2 to 5 days (Blaser, 1997; Skirrow and Blaser, 2000), but up to 8 days has been reported. Half of the patients experience a febrile period with fever, malaise and abdominal pain preceding the diarrhea. Fresh blood in the stool is common, while vomiting occurs in approximately $15 \%$ of the cases. The pathological lesions seen in humans suffering from Campylobacter infection include acute inflammatory enteritis extending to colon and rectum, with terminal ileitis and colitis (Blaser, 1997). Short lasting immunity to homologous strains has been reported, and immunity has been reported under natural conditions, for instance after repeated occupational exposure. Normally the diarrhea lasts for 2 to 3 days, while discomfort can persist for weeks. The most severe cases, however, need hospitalization (Feodoroff et al., 2010). The incidence peaks in young children and again during early adulthood. In developing countries, C. jejuni infections are common in the very young children ( $<5$ years), causing watery diarrhea (Lengerh et al., 2013), while adults are only infrequently affected due to acquired immunity (Kotloff et al., 2013; Allos, 2001). Only a few hundred cells are thought to cause infections (Robinson, 1981), but as no dose-response for symptoms was detected (Black et al., 1988) interpretation of the infectious dose from the data of experimental infections is complicated because, interpretation of the conditional fraction that go onto disease was problematic. Medema et al., (1996) using the experimental data of Black et al., (1988) fitted it to a Beta-Poisson dose-response model but considered the low dose data too unreliable to be of value (further discussion of appropriate dose-response models and parameter estimates can be found in chapter Risk Assessment for Sanitation). While data on the infectious dose of $C$. coli are not available from human volunteer studies, data from waterborne outbreaks suggests the infection dose is low (Guzman-Herrador et al., 2015).

The most severe, but rare complication following a $C$. jejuni infection is Guillain-Barré syndrome (GBS) (incidence in developed regions range from 0.4 to 4.0 cases per $100,000)$, a postinfectious autoimmune disorder of the peripheral nervous system. Up to $20 \%$ of the patients having GBS require mechanical ventilation. However, mortality rates of GBS have been reduced to 2 to $3 \%$ in the developed regions, although it remains higher in less developed area (Allos, 1997; Tam et al., 2007). Reactive arthritis is another complication following $1 \%$ to $5 \%$ of campylobacteriosis cases, and mainly affects the bigger joints, but even the smaller joints can be involved (Hannu et al., 2002; Townes, 2010). Other rare complications include extra-intestinal infections and bacteremia, occurring mainly in immune-compromised patients. Furthermore, several studies have reported an association between $C$. jejuni infection and post-infectious irritable bowel syndrome (IBS) as well as inflammatory bowel disease (IBD) (Marshall et al., 2006; Kirkpatrick and Tribble, 2011). These postinfectious complications increase the DALY of the disease.

In most cases campylobacteriosis is self-limiting and does not require any antimicrobial treatment. However, macrolides or quinolones are used in severe, complicated or systemic infections or in immune-compromised patients (Allos, 2001). Increased worldwide resistance to fluoroquinolones has, however, made the treatment management more complex.

\subsection{Taxonomic Classification of the Agent(s)}

The family Campylobacteraceae includes the genera Arcobacter, Sulfurospirillum, Dehalospirillum and Campylobacter and are Gram-negative, generally microaerophilic organisms with a low $\mathrm{G}+\mathrm{C}$ content and a relatively small genome. Currently, 29 species and 12 subspecies are classified in the genus Campylobacter, of which seven species and one subspecies were described after 2009 (http://www.bacterio.net/campylobacter.html, accessed 02.04.2015). A majority of the species are animal commensals colonising the reproductive organs, lower parts of intestinal tract or oral cavity. Several species are opportunistic or primary zoonotic pathogens. Two most clinically important species in human infections are $C$. jejuni (two subspecies, $C$. jejuni subsp. jejuni and $C$. jejuni subsp. doylei) and $C$. coli. The pathogenic role of $C$. jejuni subsp. doylei is unclear, but it has been isolated from infants with bacteremia. The two subspecies differ biochemically and can be separated by polymerase chain reaction (PCR) of nitrate reductase locus (Miller et al., 2007).

Campylobacter spp. are spiral curved rods with a polar flagellum occurring at one end of the cell that enables the display of rapid corkscrew-like darting and spinning motions (Butzler, 2004; Debruyne et al., 2008). C. jejuni is microaerophilic and a slender, spirally curved, non-spore forming, Gram-negative rod, which measures 0.2 to $0.8 \mu \mathrm{m}$ wide and 0.5 to $5 \mu \mathrm{m}$ long. In older cultures or in unfavorable environments, coccoid forms of $C$. jejuni cells are seen. Thermotolerant Campylobacter spp. are able to grow at $42^{\circ} \mathrm{C}$ but not below $30^{\circ} \mathrm{C}$, and this group includes the species $C$. jejuni, C. coli, $C$. lari and $C$. upsaliensis (ISO 17995, 2005). C. jejuni cannot utilize carbohydrates for energy (some strains utilize fucose), but rather uses amino acids and tricarboxylic acid cycle intermediates as primary energy source (Debruyne et al., 2008). C. lari strains, often isolated from wild birds and surface water, have been differentiated from $C$. jejuni and $C$. coli due to their resistance to nalidixic acid (Debruyne et al., 2008). Traditional phylogenetic analysis to describe the taxonomy of Campylobacter spp. is based on the similarity of $16 \mathrm{~S}$ rRNA gene (Debruyne et al., 2008).

\subsection{Transmission}

\subsubsection{Routes of transmission}


Most human Campylobacter infections are thought to be food- or waterborne (Allos, 2001; Guzman-Herrador et al., 2015; Mughini Gras et al., 2012; Pitkänen, 2013). C. jejuni and C. coli are zoonotic pathogens which have a broad variety of different animal hosts (Wagenaar et al., 2015). This extremely broad host spectrum from domestic and pet animals through mammalian wildlife to wild birds gives for this organism an almost unique position among zoonotic pathogens and makes detection of all potential sources and transmission routes very complicated. Fecal contamination of the food chain and environment transmits Campylobacter to human foods, recreational water and drinking water. Further, fecal material of infected persons (symptomatic and asymptomatic) spread the organisms . back to environment through human excreta and sewage systems. Fecal input is high and increases the possibility that susceptible humans will become infected by fecal-oral route through contaminated food and water both in highly developed as well as in less developed regions. Direct contact with animals is also a likely route of transmission. Fly borne transmission has also been postulated. Person-to person transmission is infrequent and has only been described in young children (Butzler, 2004). A diagram emphasizing the cyclic nature of $\mathrm{C}$. jejuni and $\mathrm{C}$. coli transmission from animal reservoirs and human excreta through food and water environment is presented in Figure 1.

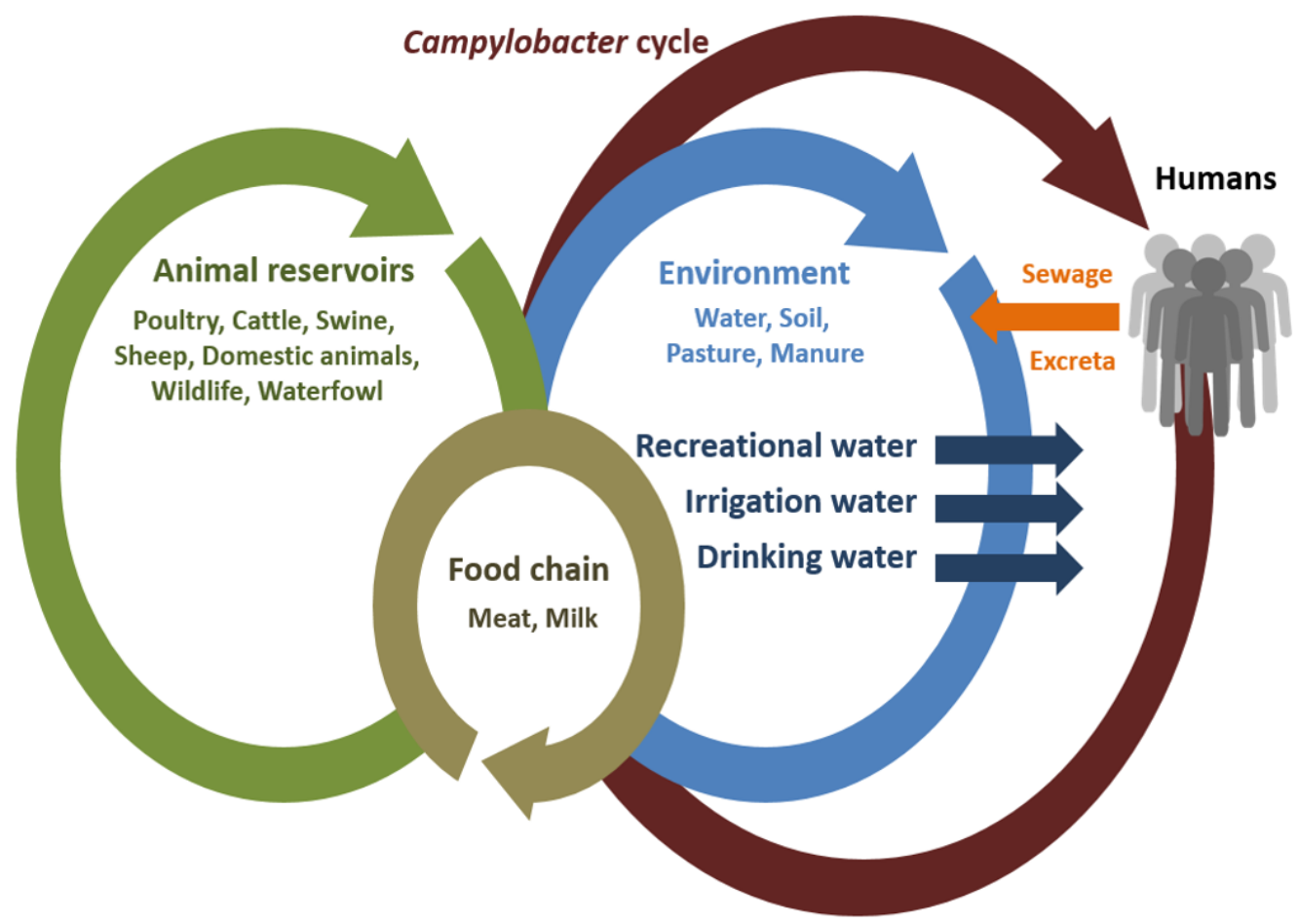

Figure 1. Cyclic nature of Campylobacter spp. transmission from animal reservoirs to humans through fecal contamination of food and water. Adapted with permission from Christian Penny, LIST, Luxembourg

\subsubsection{Reservoirs}

A wide variety of animal species carry $C$. jejuni and $C$. coli as commensals in their intestines, being potential reservoirs and sources of human infections (Ogden et al., 2009). During the last 10 to 15 years when modern population genetic tools, such as multilocus sequencing typing (MLST) has been more systematically applied to characterize Campylobacter populations colonizing different animal species and human patients, new information on the role of different animal species as reservoir/source has accumulated (Kärenlampi et al., 2007). These studies often show that certain animal species are more often colonized with MLST types overlapping with of those of human patients (generalist types) indicating that they could be a reservoir/source (de Haan et al., 2010; Sheppard et al., 2009; Lévesque et al., 2013). Further source attribution models combining MLST data and mathematical modeling indicate which animal reservoirs play the most important role in human infections (MughiniGras et al., 2012; de Haan et al., 2010). Several animal species also have MLST types which are strictly associated with the host. These types do not commonly occur in other animal species or human patients (host-adapted types) and they can be regarded as less virulent even though more data will be required for final conclusions (Cody et al., 2015; Llarena et al, 2015a). The most relevant reservoirs/sources of human infections are presented next.

\subsubsection{Livestock - cattle and sheep}

In addition to avian sources, dairy and beef cattle are typically colonized by $C$. jejuni and $C$. hyointestinalis. Colonization is age dependent with young animals are more often carrying $C$. jejuni than older animals. Both slaughterhouse surveys as well farm studies show variations in prevalence (between $12.5 \%$ and $89.4 \%$ ) depending on study (Wesley et al., 2000; Nielsen, 2002; Gilpin et al., 2008; Kwan et al., 2008; Hakkinen et al., 2007). Within-herd prevalence, similarly, will vary depending on study site from $0 \%$ to $100 \%$ in dairy cattle (Gilpin et al., 2008; Pradhan et al., 2009; Hakkinen et al., 2007), and from $5.4 \%$ to $83 \%$ in beef cattle (Inglis et al., 2004; Berry et al., 2006; Oporto et al., 2007). The bacterial counts in bovine fecal samples are usually low $\left(<10^{3}\right.$ per 
gram) and therefore often detected only by enrichment (range in different studies: not detected up to $10^{6}$ per gram) but temporary fluctuations in counts are common. In different source attribution models bovine as source has presented approximately 20 to $40 \%$. Raw milk-associated outbreaks are common indicating that $C$. jejuni strains colonizing cattle are capable of infecting humans. Further, reports from case-control studies have also identified the consumption of unpasteurised milk as an important risk factor for campylobacteriosis among humans (Studahl and Andersson, 2000; Kapperud et al., 2003; Neimann et al., 2003; Michaud et al., 2004) as well as handling raw beef (Schönberg-Norio et al., 2004). Molecular epidemiological studies have shown overlapping genotypes between cattle and humans further revealing that cattle can be a source of human infection. Certain MLST types such as ST-61 have adapted to cattle, but are also able to cause symptomatic infections in humans. Also sheep can be colonized by $C$. jejuni and $C$. coli genotypes overlapping with those isolated from human patients, as reported in Scotland (Sheppard et al., 2009). In principle several other animal species carrying Campylobacter spp. can be source of human infections but these are usually sporadic cases.

\subsubsection{Poultry}

Epidemiology studies performed during the last 30 years clearly indicate that poultry, especially, chickens are one of the most important reservoirs/sources of human campylobacteriosis worldwide (Skirrow, 1977; Llarena et al., 2015; Wagenaar et al., 2015). According to recent evaluation by EU Biohazard Panel (EFSA, 2011), 20 to 30\% of human Campylobacter infections in the EU member states can be explained by handling and consumption of contaminated chicken meat (direct exposure), but chicken production as whole plays major role (explains 30 to $50 \%$ of cases) because chicken production acts as amplification and generation site of Campylobacter (reservoir). The bacteria can spread from farms, slaughterhouses and through other routes to the environment, causing human exposure through environmental vehicles (Figure 1). The reason why poultry is an important source of $C$. jejuni and also $C$. coli is that their prevalence in commercial flocks is up to $70 \%$ in many industrialized countries, yet there are significant spatial and temporal differences in prevalence (EFSA, 2015; Kovats et al., 2005). In industrialized countries chickens are produced in units containing 10,000 to 50,000 birds per a house and a farm can have several houses where birds are reared for five to seven weeks (differences in the breeding times exist). Commonly if a flock is Campylobacter positive, all birds carry the bacterium in their intestines, at concentrations up to $10^{8}$ per gram of fecal material at time of slaughter. Industrialized production cycles have usually strict biosecurity control systems protecting the production from contamination. However, the capability to have high biosecurity level during all production steps is challenging. Biosecurity also includes the safe handling of the animal waste including manure and slaughterhouse waste, which are treated in scheduled ways to prevent pathogens (Campylobacter spp.) spreading to the outside environment (EFSA, 2011).
The UN report's the world's stock of chickens was 19 billion in 2012, meaning almost three chickens per a human being

(http://www.thepoultrysite.com/focus/global-poultry-trends/ 2400/global-poultry-trends-region-

select-track-poultry-trends-across-the-world, accessed 07.02.2016). The production is centralized: $50 \%$ of the poultry production takes place in tree countries, USA, Brazil and China. In the EU, approximately 6 million chickens are slaughtered each year. The production is local but the market is global meaning that the ecology of Campylobacter is mostly local concerning the transmission of the strains but also spreading globally through exported meat contaminated by Campylobacter. On the other hand free range and organic production systems are increasing and may cause even higher contamination risks in production. The situation in rural developing areas can be different because on those regions poultry production often happens at small scale at family-own farms where humans, poultry and other animals are living in close contact (backyard rearing) making the spreading of Campylobacter strains between different hosts and the environment including water a common phenomenon.

1.3.2.3 Wild birds

Wild birds are a huge diverse group of different bird species with differing ecologies and life styles that also represent an important reservoir and source of Campylobacter species causing human infections (Cody et al., 2015; Llarena et al., 2015a; Muchini-Gras et al., 2012; Kwan et al., 2014; Griekspoor et al., 2013). They can cause a direct transmission through their use as foods or transmit indirectly by contaminating foods, bathing water or drinking water reservoir by fecal material and they can work as reservoirs to transmit Campylobacter spp. to domestic and other wild animals (Wagenaar et al., 2015). There are both bird species which have their life cycles locally and species which migrate long distances and are then able to transmit Campylobacter spp. between distantly located areas. Studies performed on different areas in the world from all continents to Antarctica reveal that Campylobacter spp. are widely spread among wild birds (Griekspoor et al., 2013). Several Campylobacter species colonize birds, most important are $C$. jejuni, $C$. coli and $C$. lari, a bird-adapted species. Most studies are targeted on wild birds as reservoir transferring Campylobacter spp. to domestic animals or humans. Bird species seem to differ how commonly they carry Campylobacter spp.; some have high prevalence and some low or nonexistent colonization. Bird species known to be commonly colonized are ducks (family Anatidae), shorebirds (several families), corvids, gulls, pigeons, doves, thrushes and starlings (Griekspoor et al., 2013). Bird species which are living in close connection to agriculture and other human activities (urban areas, close to landfills etc.) seem to be often colonized. Epidemiological studies show evidence that fecal contamination of non-disinfected drinking water by wild bird feces has been associated to some waterborne outbreaks (Pitkänen et al., 2008). However, comparison of wild bird and human patient isolates seldom indicate overlapping sero- or genotypes thus making final conclusion on the role of wild birds as contamination 
sources unclear. Modern molecular genotyping methods are applied and used to compare similarity of genotypes of wild birds and human patients or domestic animals. MLST typing in combination with mathematical source attribution models have been applied and they generally show that some types overlap between humans, animals and birds (ST-45, ST-48, ST-21 and ST-257) but birds also have types which seem to be unique for the species (e.g. ST 1034 in barnacle geese (Llarena et al., 2015a). Interestingly the bird-associated MLST types occur in certain bird species all over the world further supporting the idea on hostassociated types. A recent UK study using MLST typing data and a mathematical model estimated that wild birdattributed isolates could account annually for 2 to $3 \%$ of human cases in Oxfordshire, UK (Cody et al., 2015). Also isolated outbreaks point to human-infectious $C$. jejuni in some flocks of waterfowl (e.g. Sandhill Cranes [Lu et al., 2013]), versus largely absent in others (e.g. California Gull [Lu et al., 2011]).

1.3.2.4 Water and soil

Waterborne Campylobacter spp. are likely to originate from recent fecal contamination of water by waterfowl and farm animal manure runoff, in addition to discharges of poorly or non-disinfected sewage effluent or septic seepage (Koenraad et al., 1994; Obiri-Danso and Jones, 1999; Abulreesh et al., 2006; Kuusi et al., 2005; Jokinen et al., 2010; Hellein et al., 2011). River and lake water have several potential contamination sources such as cattle and sheep on pasture and manure spreading on fields within watersheds, direct fecal contamination by wild birds and animals, human untreated waste in some regions and treated municipal wastewater (Figure 1). The relative importance of different sources and extent of contamination is highly dependent upon the hydrogeology of the watershed. While farming and urban areas are important sources, remote regions may still have Campylobacter contamination due to wild animals. Also, bacterial discharge from farmland to waterways is highly dependent on rain/snow events that mobilize fecal deposits (Muirhead et al., 2006; Ferguson et al., 2010). Humans may also acquire campylobacteriosis from natural water by bathing, recreation/canoeing, or drinking directly from within the watershed.

\subsubsection{Incubation period}

Campylobacter infection is an acute self-limited gastrointestinal illness with an incubation period that is longer than most other intestinal infections: commonly two to five days but up seven days have been reported. The mean incubation period is 3.2 days ranging approximately from 1 to 10 days (Blaser, 1997; Feodoroff et al., 2010; Nichols et al., 2012).

\subsubsection{Period of communicability}

Patients shed high numbers of $C$. jejuni in voided material during their symptomatic infection phase, which commonly last three to five days. Duration of shedding lasts from a few hours to three weeks (average 15 days) (Nichols et al., 2012; Feodoroff et al., 2010; Butzler, 2004). Limited data is available on the concentration in human feces, but in three patients' concentrations varied from $6 \times 10^{6}$ to $10^{9}$ CFU/g (Blaser and Wang, 1980). Nonetheless, human-tohuman transmission of Campylobacter is uncommon (Blaser, 1997).

Campylobacter enteritis most frequently affects children aged $<4$ years and the infection rate is higher in boys and adult males than in girls and adult females (Allos, 2001; Kotloff et al., 2013). The infection frequency displays a strong seasonal variation in temperate climates with infections being more common in summer than in winter (Nylen et al., 2002; Schönberg-Norio et al., 2004; Kovats et al., 2005). The reason for the summer peak of human infections remains unknown but it may be affected by the higher prevalence of sporadic foodborne infections together with higher probability of waterborne outbreaks in conjunction with summer activities, such as outdoor food handling practices and the use of non-community water supplies (Olson et al., 2008). The seasonal variation is less distinct in tropical and subtropical areas (Kovats et al., 2005) and fly transmission has been hypothesized as an explanatory factor (Nichols, 2005).

\subsubsection{Population susceptibility}

Antibodies to Campylobacter antigens are present for several months conferring a short-term immunity to the homologous strain (Black et al., 1992). In developed regions where infections are uncommon, population level immunity is usually low and active immunity after symptomatic infection disappears rapidly and does not provide protective immunity against non-homologous strains (Allos, 2001; Blaser, 1997). Occupational exposure (farmers, slaughterhouse workers etc.) may acquire immunity and may occasionally be asymptomatic shedders of campylobacters (Ellström et al., 2014). Epidemiological features of infections in low-income countries suggest that due to several infection episodes in childhood leading to acquired immunity, older persons rarely experience symptomatic infection but may shed the pathogen.

\subsection{Population and Individual Control Measures}

\subsubsection{Vaccines}

Several attempts have been performed to develop a vaccine either for prevention of human infections or more commonly vaccines to prevent colonization of chickens by $C$. jejuni and so reduce its spread to humans. Currently, there is no vaccine approved by any global regulatory authority to prevent Campylobacter-associated illness. Biological feasibility of human vaccine development is supported by data from epidemiologic and human challenge studies. Several candidates are under development (http://www.who.int/immunization/research/meetings_work shops/Campylobacter_VaccineRD_Sept2014.pdf).

\subsubsection{Hygiene measures}

Hygienic food preparation needs high quality water in food production and related processing areas (for cleaning 
food handing surfaces and utensils, hands etc.). Further, availability for proper hand washing facilities, toilets and clean water are of primary importance for safe food production. The prevention of fecal contamination of drinking water and maintenance of a residual chlorine concentration in the distributed drinking water are critical control measures to reduce the numbers of waterborne Campylobacter infections in regions with centralized water supplies and distribution. Private wells should be protected from fecal contamination by constructing them in such a manner that any fecal contamination source is not close to well and surface water cannot contaminate the well, e.g. after heavy rain/flooding. Protection of raw water sources from fecal contamination is one of the first hygienic measures, promoting the production of drinking water in a way requiring less costly water treatment (http://www.who.int/water_sanitation_health/en/). Many cases of $C$. jejuni infections are associated with drinking water cross-connection with wastewater infrastructure (Pitkänen, 2013). The water safety plan (WSP) approach introduced by WHO is a risk management framework that supports the production of high quality drinking water worldwide with multiple benefits (Gunnarsdóttir et al., 2012).

\subsection{Environmental Occurrence and Persistence}

\subsection{Detection Methods}

Campylobacter detection methods have been developed since Campylobacter jejuni was first isolated from the feces of patients with gastrointestinal disease in the 1970s (Dekeyser et al., 1972) and include culture-based and direct molecular methods. Campylobacter species are fastidious bacteria that are oxygen sensitive and are grown in a microaerobic atmosphere containing 3 to $10 \%(\mathrm{v} / \mathrm{v})$ oxygen and 5 to $10 \%(\mathrm{v} / \mathrm{v})$ carbon dioxide (Kelly, 2001). Some species also require hydrogen for their growth. Colonies directly grown on solid media are usually incubated at $41.5^{\circ} \mathrm{C}$ with fecal samples that usually contain high numbers of viable Campylobacter cells (Jacobs-Reitsma et al., 2008; Ugarte-Ruiz et al., 2012). Thermotolerant Campylobacter can also be cultivated from feces or mixed environmental media with antimicrobial-containing selective media (blood-based or charcoal blood-free) under microaerophilic conditions at an elevated temperature $\left(42^{\circ} \mathrm{C}\right)$. However, initial liquid enrichment is generally used before plating on solid selective media to promote the recovery of low numbers of cultivable Campylobacter cells from environmental samples (Hänninen et al., 2003; JacobsReitsma et al., 2008; Kim et al., 2016). The selective agents most often used include cefoperazone, amphotericin B, trimethoprim and vancomycin, and the media also contain sterile sheep or horse blood, or charcoal to neutralize the toxic effects of oxygen and light (Jacobs-Reitsma et al., 2008; Kim et al., 2016).

Since cultivation of Campylobacter spp. requires specific conditions including microaerobic atmosphere, the isolation of Campylobacter spp. from water is rarely successful or attempted, and was only reported in eight out of the 29 outbreaks reviewed by Pitkänen (2013). Thus far, studies have shown that it is difficult to isolate Campylobacter spp. from water related to waterborne Campylobacter outbreaks mainly due to insufficient and delayed water sampling and analysis (Bopp et al., 2003; Hänninen et al., 2003; Jakopanec et al., 2008). Generally, failure to isolate Campylobacter spp. is due to deficiencies in the detection methods applied to water samples (Rollins and Colwell, 1986; Jacobs-Reitsma et al., 2008), i.e. insufficient sample volumes and selective culture (Miller and Mandrell, 2005). The current standard method for the detection of thermotolerant Campylobacter species from water is based on membrane filtration as an initial concentration step (ISO 17995, 2005), followed by liquid enrichment before plating onto a solid selective medium, so as to recover low numbers of Campylobacter cells usually existing in environmental samples (Hänninen et al., 2003, Jacobs-Reitsma et al., 2008; Ugarte-Ruiz et al., 2015). Enrichment using Bolton broth is the primary method used for isolation of Campylobacter spp. in drinking water (ISO $17995,2005)$, and the use of increased sample volume is recommended even though it may require the use of larger diameter filters (Hijnen et al., 2000) than the conventional $47 \mathrm{~mm}$ in cases where the water under examination is turbid. Direct plating methods employed for stool samples are unsuitable for quantitative recovery of low numbers of Campylobacter spp. present in environmental samples (Rollins and Colwell, 1986, Hänninen et al., 2003), and in water with high microbial biomass, non-targeted bacterial groups may out-compete the growth of Campylobacter spp. during the enrichment step (Abulreesh et al., 2005). For sewage influent and effluent samples, the selectivity of the enrichment may be increased by use of Preston broth at an elevated temperature of $41.5^{\circ} \mathrm{C}$ instead of $37^{\circ} \mathrm{C}$ (Koenraad et al., 1995) and a $21 \mathrm{~h}$ enrichment time as compared to the standard time of $44 \mathrm{~h}$ (Pitkänen, 2013), or addition of a wider range of antimicrobial agents (Kim et al., 2016). Alternatively a filter method, where motile Campylobacter spp. move through the pores in membrane filter on unselective medium prior to incubation at the growth temperature, have been used for separation of Campylobacter spp. from the non-target bacteria (Diergaardt et al., 2004; Rechenburg and Kistemann, 2009).

Methods for species identification and strain typing are not matrix-dependent, i.e. any method available for Campylobacter typing may be utilized in further characterization of Campylobacter isolates. The traditional subtyping methods include phenotyping, serotyping, biotyping, and phage typing (Butzler, 2004). The minimum standard for identifying Campylobacter spp. includes colony morphology, Gram's stain, motility, and an oxidase test. To separate $C$. jejuni from $C$. coli, a hippuratehydrolysis test has traditionally been used, although there are also hippurate-negative $C$. jejuni (Totten et al., 1987).

More recently, a wide range of nucleic acid-based methods have been used to confirm presumptive Campylobacter isolates from media. Due to the biochemical inertness of Campylobacter spp., molecular methods such as PCR and sequencing of the 16S rRNA gene are now generally used to differentiate Campylobacter-species. However, the sequence variability in the $16 \mathrm{~S}$ rRNA gene in $C$. jejuni and $C$. coli does not differentiate these species, 
necessitating the use of other gene targets of PCR and sequencing of the amplicon, for example, the hipO-gene (Linton et al., 1996) or groEL- and rpoB-gene (Kärenlampi et al., 2004; Korczak et al., 2006). Indeed, PCR methods targeted to hipO gene may provide a more accurate differentiation between $C$. jejuni and $C$. coli than the phenotypic hippurate test (Abu-Halaweh et al., 2005; Abulreesh et al., 2006; Jensen et al., 2005). In addition, matrix-assisted laser desorption ionization-time of flight mass spectrometry (MALDI-TOF MS) (Mandrell et al., 2005) and a number of genotyping methods, such as pulsed-field gel electrophoresis (PFGE), restriction fragment analysis of Campylobacter flagellin genes (flaRFLP), amplified fragment length polymorphism (AFLP), MLST) and direct sequencing (Butzler, 2004; On et al., 2008; Wassenaar and Newell, 2000; Clark et al., 2003; Kovanen et al., 2014) can be used to aid in the identification of Campylobacter species.

Recently whole genome MLST (wgMLST) has been increasingly applied for studies of outbreak-associated $C$. jejuni isolates (Kovanen et al., 2016). A recent study using wgMLST of $C$. jejuni isolates from a waterborne outbreak revealed that sometimes pulsed-field gel electrophoresis (PFGE) may overestimate the clonal relationship between some of the apparent outbreak-related $C$. jejuni strains (Revez et al., 2014). It is possible that in previous years, when PFGE was solely utilized for genotyping of outbreak isolates, some unrelated, sporadic human cases were mistakenly classified as part of the waterborne outbreaks. The use of molecular tools such as wgMLST is increasing in outbreak investigations (Moffatt et al., 2016).

The reliance on conventional cultivation alone for Campylobacter spp. detection and subsequent subtyping is not practical, since viable but not culturable (VBNC) Campylobacter cells occur (Tholozan et al., 1999; Abulreesh et al., 2006; Bronowski et al., 2014; Oh et al., 2015). The coupling of PCR detection after enrichment to the culture-based method increases the work load but substantially shortens the time requirement for detection and confirmation of Campylobacter spp. (i.e. from two or more days down to five hours). The use of PCR after enrichment may reduce the presence of false negative analysis results in cases where the Campylobacter colonies are overgrown by the growth of non-target bacteria on a solid agar medium. Ideally quantitative real-time PCR for Campylobacter detection should been applied directly to water samples (Nogva et al., 2000; Yang et al., 2003; Nam et al., 2005; VanDyke et al., 2010; Clark et al., 2011; Park et al., 2011). These studies have utilized Campylobacter PCR assays targeting the 16S rRNA gene (Bang et al., 2002; Moreno et al., 2003; Josefsen et al., 2004; Hellein et al., 2011), the 23S rRNA gene (Engvall et al., 2002), 16S-23S rDNA internal transcribed (ITS) region (Khan and Edge, 2007) and the flagellin genes flaA and flaB (Waage et al., 1999; Moore et al., 2001). Other molecular assays reported have targeted genes such as glyA (Jensen et al., 2005), gafF and ceuE (Nayak et al., 2005; Hellein et al., 2011), ORF-C sequence (Sails et al., 2003) and cpn60 gene (Banihashemi et al., 2012).

However, the problem of detecting both viable and non- viable cells has so far restricted applications of PCR techniques. Therefore, techniques differentiating living from dead cells have been studied and may well provide novel tools for rapid and accurate detection of viable microbes (Cenciarini-Borde et al., 2009; Fittipaldi et al., 2012; Pitkänen et al., 2013). For example, it has been suggested that RT-qPCR assay based Campylobacter spp. specific rRNA signals are associated to active bacterial populations in environmental waters since they were in better agreement with the culture-based results of thermotolerant Campylobacter spp. than that of rDNAbased assays (Pitkänen et al., 2013). Novel molecular platforms such as isothermal amplification techniques and high-throughput sequencing approaches may provide new possibilities for Campylobacter spp. detection. Isothermal amplification coupled with microarrays provide opportunity to simultaneously study a large number of microbial targets, including genes of $C$. jejuni in less than 20 minutes (Tourlousse et al., 2012).

\subsection{Data on Occurrence}

\subsubsection{Excreta in environment}

Campylobacter spp. occurrence data in human fecal waste other than sewage is limited. Further, there are gaps in the incidence data (see Table 1) especially from developing regions where waterless or no sanitation systems occur. Nonetheless, Campylobacter spp. are one of the most frequently occurring pathogens causing human gastrointestinal diseases worldwide, hence, always present in community fecal waste.

Most warm-blooded animals are asymptomatic carriers of Campylobacter spp. The presence of Campylobacter spp. in mammal and bird feces: cat, dog, cow, seagull, chicken, duck, geese and pigs is commonly reported (Hellein et al., 2011). For example, in Canada, the presence of Campylobacter spp. was shown in a total of 37 animal fecal samples (35.6\%) out of 104 samples collected from goat, cow, chicken, goose, duck and pig feces (Jokinen et al., 2010). However, Campylobacter spp. was absent from rabbit and rat feces and present in less than $15 \%$ of horse, dog, llama, alpaca and sheep fecal samples $(n=113$; Jokinen et al., 2010). In Queensland, Australia, 24 out of 40 possum fecal samples $(60 \%)$ contained $2.0 \times 10^{5}$ to $2.0 \times 10^{7}$ Campylobacter spp. cells/g (Ahmed et al., 2012). In the same study, $24 \%$ of bird fecal samples had $6.6 \times 10^{4}$ to $6.6 \times 10^{6}$ Campylobacter spp. cells/g $(n=38)$. Noting that the presence of animal Campylobacter spp. does not mean they are infectious in humans, strain typing is necessary (e.g. Mughini Gras et al., 2013).

\subsubsection{Sewage}

Sewage is a major source of Campylobacter spp. in the environment. Septic seepage into well waters and crossconnections between sewerage and drinking water systems have caused several waterborne outbreaks (Pitkänen, 2013). Non-disinfected wastewater effluents discharge Campylobacter spp. to environmental waters (LauriaFilgueiras and Hofer, 1998; Hokajärvi et al., 2013; Rechenburg and Kistemann, 2009). Table 2 summarizes the 
Table 2. Occurrence of Campylobacter in sewage, effluents and sludges

\begin{tabular}{|c|c|c|c|c|c|c|}
\hline Area & $\begin{array}{l}\text { Period of } \\
\text { Study }\end{array}$ & Pathogen Type & $\begin{array}{c}\text { Sample Volume/ } \\
\text { Method }\end{array}$ & $\begin{array}{l}\text { Percent Positive } \\
\text { (\# of Samples) }\end{array}$ & $\begin{array}{c}\text { Concentrations } \\
\text { Average (Ranges) } \\
\text { MPN }^{\mathrm{a}}, \text { CFU }^{\mathrm{b}} \\
\text { or Cells }^{\mathbf{c}} / \mathbf{L}\end{array}$ & Reference \\
\hline \multicolumn{7}{|c|}{ Matrix raw sewage } \\
\hline \multirow{3}{*}{$\begin{array}{l}\text { Brazil (Rio } \\
\text { de Janeiro) }\end{array}$} & \multirow{3}{*}{1990 to 1991} & $\begin{array}{c}\text { Campylobacter } \\
\text { spp. }\end{array}$ & $\begin{array}{c}120 \mathrm{ml} \\
\text { centrifuged at }\end{array}$ & $\begin{array}{c}52.3 \% \\
(68 / 130)\end{array}$ & \multirow{3}{*}{$\mathrm{NR}^{\mathrm{d}}$} & \multirow{3}{*}{$\begin{array}{l}\text { Lauria-Filgueiras } \\
\text { and Hofer, } 1998\end{array}$} \\
\hline & & C. jejuni & $\begin{array}{l}3000 \text { rpm for } 30 \\
\text { min or Moore's }\end{array}$ & $\begin{array}{c}23.8 \% \\
(31 / 130)\end{array}$ & & \\
\hline & & C. coli & $\begin{array}{c}\text { swab adaptations } \\
\text { Culture }\end{array}$ & $\begin{array}{c}13.1 \% \\
(17 / 130)\end{array}$ & & \\
\hline $\begin{array}{l}\text { Canada } \\
\text { (British } \\
\text { Columbia) }\end{array}$ & 2004 to 2006 & $\begin{array}{c}\text { Campylobacter } \\
\text { spp. }\end{array}$ & $\begin{array}{l}500 \mathrm{~mL} \\
\text { Culture }\end{array}$ & $\begin{array}{l}36.4 \% \\
(4 / 11)\end{array}$ & $\begin{array}{c}\text { NR } \\
(C . \text { jejuni } \\
\text { confirmed by PCR } \\
\text { from all positive } \\
\text { samples) }\end{array}$ & $\begin{array}{c}\text { Jokinen et al., } \\
2010\end{array}$ \\
\hline $\begin{array}{l}\text { Germany } \\
\text { (North-Rhine } \\
\text { Westphalia) }\end{array}$ & NR & $\begin{array}{c}\text { Campylobacter } \\
\text { spp. }\end{array}$ & $\begin{array}{c}100 \mathrm{~mL}, 10 \mathrm{ml} \\
\text { and } 1 \mathrm{ml} \text { or less } \\
\text { using dilutions } \\
\text { Culture }\end{array}$ & $\begin{array}{c}\% \mathrm{NR} \\
(39)\end{array}$ & $\begin{array}{c}\text { 1.1E+06 CFU } \\
\text { (median) } \\
(1.0 \mathrm{E}+02 \text { to } \\
1.0 \mathrm{E}+07 \mathrm{CFU})\end{array}$ & $\begin{array}{l}\text { Rechenburg and } \\
\text { Kistemann, } 2009\end{array}$ \\
\hline $\begin{array}{l}\text { Germany } \\
\text { (Weisse } \\
\text { Elster) }\end{array}$ & NR & $\begin{array}{c}\text { Campylobacter } \\
\text { spp. }\end{array}$ & $\begin{array}{c}\text { NR } \\
\text { Culture }\end{array}$ & $\begin{array}{c}\% \mathrm{NR} \\
(13)\end{array}$ & $1.1 \mathrm{E}+04 \mathrm{CFU}$ & $\begin{array}{l}\text { Stelzer and } \\
\text { Jacob, } 1991\end{array}$ \\
\hline $\begin{array}{l}\text { Italy } \\
\text { (Bologna) }\end{array}$ & 1990 to 1991 & $\begin{array}{l}\text { Campylobacter } \\
\text { spp. }\end{array}$ & $\begin{array}{c}1 \mathrm{~mL}, 0.1 \mathrm{~mL} \text { and } \\
0.01 \mathrm{~mL} \\
\text { Culture }\end{array}$ & $\begin{array}{c}\% \text { NR } \\
(22)\end{array}$ & $1.6 \mathrm{E}+04 \mathrm{MPN}$ & $\begin{array}{c}\text { Stampi et al., } \\
1992\end{array}$ \\
\hline \multirow{3}{*}{$\begin{array}{l}\text { Italy } \\
\text { (Piedmont } \\
\text { region) }\end{array}$} & \multirow{3}{*}{2014 to 2015} & $\begin{array}{c}\text { Campylobacter } \\
\text { spp. }\end{array}$ & $100 \mathrm{~mL}$ & $\begin{array}{c}83 \% \\
(10 / 12)\end{array}$ & NR & \multirow{3}{*}{$\begin{array}{c}\text { Bonetta et al., } \\
2016\end{array}$} \\
\hline & & C. jejuni & $\begin{array}{l}\text { Gene detection } \\
\text { (PCR after } \\
\text { enrichment) }\end{array}$ & $\begin{array}{c}50 \% \\
(6 / 12)\end{array}$ & NR & \\
\hline & & C. coli & & $\begin{array}{l}25 \% \\
(3 / 12)\end{array}$ & NR & \\
\hline $\begin{array}{l}\text { Spain } \\
\text { (Catalonia) }\end{array}$ & 2004 to 2006 & $\begin{array}{c}\text { Campylobacter } \\
\text { spp. }\end{array}$ & $\begin{array}{c}0.0001 \text { to } 10 \mathrm{~mL}, \\
\text { centrifugation at } \\
7700 \mathrm{~g} \text { for } 20 \mathrm{~min} \\
\text { Culture }\end{array}$ & $\begin{array}{l}85.7 \% \\
(24 / 28)\end{array}$ & $\begin{array}{c}2.5 \mathrm{E}+03 \mathrm{MPN} \\
\text { (geomean) } \\
(<4.0 \mathrm{E}+01 \text { to } \\
1.5 \mathrm{E}+05 \mathrm{MPN})\end{array}$ & $\begin{array}{c}\text { Rodriguez and } \\
\text { Araujo, } 2010\end{array}$ \\
\hline $\begin{array}{l}\text { USA } \\
\text { (Pensacola, } \\
\text { Florida) }\end{array}$ & 2008 to 2009 & $\begin{array}{c}\text { Campylobacter } \\
\text { spp. }\end{array}$ & $\begin{array}{c}10 \mathrm{~mL} \\
\text { qPCR for cell } \\
\text { counts, PCR for } \\
\text { speciation }\end{array}$ & $\begin{array}{c}26.3 \% \\
(15 / 57)\end{array}$ & $\begin{array}{l}4.1 \mathrm{E}+06 \text { Cells } \\
\text { (mean of +ve) } \\
(<1.0 \mathrm{E}+02 \text { to } \\
6.2 \mathrm{E}+07 \text { Cells) }\end{array}$ & $\begin{array}{l}\text { Hellein et al., } \\
2011\end{array}$ \\
\hline \multicolumn{7}{|c|}{ Matrix sewage effluent ${ }^{\mathrm{e}}$} \\
\hline \multirow{3}{*}{$\begin{array}{l}\text { Brazil (Rio } \\
\text { de Janeiro) }\end{array}$} & \multirow{3}{*}{1990 to 1991} & $\begin{array}{c}\text { Campylobacter } \\
\text { spp. }\end{array}$ & $120 \mathrm{ml}$ & $\begin{array}{c}25.4 \% \\
(33 / 130)\end{array}$ & \multirow{3}{*}{ NR } & \multirow{3}{*}{$\begin{array}{c}\text { Lauria-Filgueiras } \\
\text { and Hofer, } 1998\end{array}$} \\
\hline & & C. jejuni & $\begin{array}{l}\text { centrifuged at } \\
3000 \text { rpm for } 30 \\
\text { min or Moore's }\end{array}$ & $\begin{array}{c}6.2 \% \\
(8 / 130)\end{array}$ & & \\
\hline & & C. coli & swab adaptations & $\begin{array}{c}4.6 \% \\
(6 / 130)\end{array}$ & & \\
\hline Finland & 2006 to 2007 & $\begin{array}{c}\text { Campylobacter } \\
\text { spp. }\end{array}$ & $\begin{array}{l}0.1,1 \text { and } 10 \mathrm{~mL} \\
\text { Culture }\end{array}$ & $\begin{array}{c}52.9 \% \\
(18 / 34)\end{array}$ & $\begin{array}{l}\text { 5.0E+02 CFU } \\
\text { (median) }\end{array}$ & $\begin{array}{c}\text { Hokajärvi et al., } \\
2013\end{array}$ \\
\hline $\begin{array}{l}\text { Germany } \\
\text { (North-Rhine } \\
\text { Westphalia) }\end{array}$ & NR & $\begin{array}{c}\text { Campylobacter } \\
\text { spp. }\end{array}$ & $\begin{array}{c}100 \mathrm{~mL}, 10 \mathrm{ml} \\
\text { and } 1 \mathrm{ml} \text { or less } \\
\text { using dilutions } \\
\text { Culture }\end{array}$ & $\begin{array}{c}\% \mathrm{NR} \\
(37)\end{array}$ & $\begin{array}{c}\begin{array}{c}1.0 \mathrm{E}+03 \mathrm{CFU} \\
(\text { median})\end{array} \\
(<1.0 \mathrm{E}+01 \text { to } \\
1.0 \mathrm{E}+05 \mathrm{CFU})\end{array}$ & $\begin{array}{l}\text { Rechenburg and } \\
\text { Kistemann, } 2009\end{array}$ \\
\hline
\end{tabular}




\begin{tabular}{|c|c|c|c|c|c|c|}
\hline Area & $\begin{array}{l}\text { Period of } \\
\text { Study }\end{array}$ & Pathogen Type & $\begin{array}{c}\text { Sample Volume/ } \\
\text { Method }\end{array}$ & $\begin{array}{l}\text { Percent Positive } \\
\text { (\# of Samples) }\end{array}$ & $\begin{array}{c}\text { Concentrations } \\
\text { Average (Ranges) } \\
\text { MPN }^{\mathrm{a}}, \text { CFU }^{\mathrm{b}} \\
\text { or Cells }^{\mathrm{c}} / \mathrm{L} \\
\end{array}$ & Reference \\
\hline $\begin{array}{l}\text { Germany } \\
\text { (Weisse } \\
\text { Elster) }\end{array}$ & NR & $\begin{array}{c}\text { Campylobacter } \\
\text { spp. }\end{array}$ & $\begin{array}{c}\text { NR } \\
\text { Culture }\end{array}$ & $\begin{array}{c}\% \mathrm{NR} \\
(11)\end{array}$ & 1.3E+03 CFU & $\begin{array}{l}\text { Stelzer and } \\
\text { Jacob, } 1991\end{array}$ \\
\hline $\begin{array}{l}\text { Germany } \\
\text { (Weisse } \\
\text { Elster) }\end{array}$ & NR & $\begin{array}{c}\text { Campylobacter } \\
\text { spp. }\end{array}$ & $\begin{array}{c}\text { NR } \\
\text { Culture }\end{array}$ & $\begin{array}{c}42.8 \% \\
(3 / 7)\end{array}$ & $\begin{array}{c}\text { NR } \\
\text { (Not found in the } \\
\text { digested sludge } \\
\text { (age >90 days) }\end{array}$ & $\begin{array}{l}\text { Stelzer and } \\
\text { Jacob, } 1991\end{array}$ \\
\hline \multirow{2}{*}{$\begin{array}{l}\text { Italy } \\
\text { (Bologna) }\end{array}$} & \multirow{2}{*}{1990 to 1991} & \multirow{2}{*}{$\begin{array}{c}\text { Campylobacter } \\
\text { spp. }\end{array}$} & \multirow{2}{*}{$\begin{array}{l}50 \text { and } 100 \mathrm{~mL} \\
\text { Culture }\end{array}$} & $\begin{array}{c}\% \mathrm{NR} \\
(22)\end{array}$ & $3.0 \mathrm{E}+02 \mathrm{MPN}$ & \multirow{2}{*}{$\begin{array}{c}\text { Stampi et al., } \\
1992\end{array}$} \\
\hline & & & & $\begin{array}{c}\% \mathrm{NR} \\
(22)\end{array}$ & $\begin{array}{c}\text { Not detected } \\
\text { Post chlorination }\end{array}$ & \\
\hline \multirow{4}{*}{$\begin{array}{l}\text { Italy } \\
\text { (Piedmont } \\
\text { region) }\end{array}$} & \multirow{4}{*}{2014 to 2015} & $\begin{array}{l}\text { Campylobacter } \\
\text { spp. }\end{array}$ & \multirow{3}{*}{$\begin{array}{l}1000 \mathrm{~mL} \\
\text { Gene detection } \\
\text { (PCR after } \\
\text { enrichment) }\end{array}$} & $\begin{array}{l}42 \% \\
(5 / 12)\end{array}$ & & \multirow{3}{*}{$\begin{array}{l}\text { Bonetta et al., } \\
2016\end{array}$} \\
\hline & & C.jejuni & & $\begin{array}{c}8 \% \\
(1 / 12)\end{array}$ & NR & \\
\hline & & C. coli & & $\begin{array}{c}25 \% \\
(3 / 12)\end{array}$ & & \\
\hline & & \multicolumn{5}{|c|}{ Matrix sewage sludge } \\
\hline Sweden & NR & C. coli & $\begin{array}{l}\text { Vol NR } \\
\text { Culture }\end{array}$ & $\begin{array}{c}9 \% \\
(6 / 64) \\
(2 \%(1 / 69) \text { in } \\
\text { treated sludge })\end{array}$ & NR & $\begin{array}{c}\text { Sahlström et al., } \\
2004\end{array}$ \\
\hline Sweden & NR & C. jejuni & $\begin{array}{l}\text { Vol NR } \\
\text { Culture }\end{array}$ & $\begin{array}{c}20 \% \\
(13 / 64) \\
(4 \%(2 / 69) \text { in } \\
\text { treated sludge })\end{array}$ & NR & $\begin{array}{l}\text { Sahlström et al., } \\
2004\end{array}$ \\
\hline $\begin{array}{l}\text { The } \\
\text { Netherlands } \\
\text { (Gelderland) }\end{array}$ & 1991 to 1993 & $\begin{array}{c}\text { Campylobacter } \\
\text { spp. }\end{array}$ & $\begin{array}{l}\text { Vol NR } \\
\text { Culture }\end{array}$ & $\begin{array}{c}88 \% \\
(27 / 30)\end{array}$ & $\begin{array}{c}2.5 \mathrm{E}+03 \mathrm{MPN} \\
(3.2 \mathrm{E}+02 \text { to } 6.3 \\
\mathrm{E}+05 \mathrm{MPN})\end{array}$ & $\begin{array}{c}\text { Koenraad et al., } \\
1994\end{array}$ \\
\hline
\end{tabular}

${ }^{\mathrm{a}} \mathrm{MPN}$ : Most probable number; ${ }^{\mathrm{b}} \mathrm{CFU}$ : Colony forming units; ${ }^{\mathrm{c}} \mathrm{Quantification}$ was based on a standard curve constructed relating the number of bacterial cells to the cycle threshold (CT) of qPCR for known concentrations of bacteria determined by culture (CFU); ${ }^{\mathrm{d}} \mathrm{NR}$ : Not reported; ${ }^{\mathrm{e}}$ Activated sludge

\subsubsection{Sludge}

Table 2 summarizes the published reports of Campylobacter spp. numbers in sludge. For example, at sewage treatment plants in Sweden, 20.3\% (13/64) and $9.4 \%(6 / 64)$ of raw sludge samples contained viable $C$. jejuni and $C$. coli, respectively, whereas only $2.9 \%(2 / 69)$ and $1.4 \%(1 / 69)$ of treated sludge samples were $C$. jejuni and C. coli positive (Sahlström et al., 2004).

\subsubsection{Animal manure}

Because $C$. jejuni and $C$. coli commonly colonize a large numbers of animal hosts, their presence in fresh fecal material is common. For example, $100 \%$ presence of Campylobacter spp. in poultry wastewater $(n=13$; geometric mean $\left.6.0 \times 10^{6} \mathrm{MPN} / \mathrm{L}\right)$ and in pig slurries $(n=6$; geometric mean $4.9 \times 10^{6} \mathrm{MPN} / \mathrm{L}$ ) in Mediterranean area has been reported (Rodríguez and Araujo, 2010). Origin of manure, the manure treatment process, climate and other environmental factors play a role in the survival and numbers of Campylobacter spp. in manure and after spreading to land (Nicholson et al., 2005).

\subsubsection{Surface waters}

Campylobacter spp. are frequently isolated from fresh surface waters (Stelzer and Jacob, 1991; Koenraad et al., 1997; Jones 2001; Savill et al., 2001; Diergaardt et al., 2004; Hörman et al., 2004; Vereen et al., 2007; Hellein et al., 2011; Jokinen, et al., 2012; Hokajärvi et al., 2013). Table 3 summarizes the published studies reporting the detection of Campylobacter spp. and available Campylobacter spp. counts in surface waters. The high variability in the reported detection rates and counts of Campylobacter spp. in surface water is in part due to the different methods used for detecting Campylobacter spp. from water. For example, the Campylobacter counts have 
been analyzed by direct plating (Vereen et al., 2007), using Campylobacter spp. specific quantitative PCR methods (Hellein et al., 2011; Van Dyke et al, 2010) and by semiquantitative enrichment method (Hokajärvi et al., 2013; Diergaardt et al., 2004) - making comparison between studies rather pointless given the different forms (dead or culturable) reported. Campylobacter spp. counts also naturally vary, due to processes that mobilize them off surfaces and their dilution within surface waters (Sterk et al., 2016).

Table 3. Occurrence of Campylobacter spp. in surface waters ${ }^{\mathrm{a}}$

\begin{tabular}{|c|c|c|c|c|c|c|}
\hline Area & $\begin{array}{l}\text { Period of } \\
\text { study }\end{array}$ & $\begin{array}{c}\text { Sample Volume/ } \\
\text { Method } \\
\text { MATRIX }\end{array}$ & $\begin{array}{l}\text { Percent } \\
\text { Positive } \\
\text { (\# of } \\
\text { samples) }\end{array}$ & $\begin{array}{c}\text { Concentrations } \\
\text { Average } \\
\text { (Range) }^{-} \\
\text {MPN }^{\mathrm{b}}, \text { CFU }^{\mathrm{c}} \text { or } \\
\text { Cells }^{\mathrm{d}} / \mathrm{L} \\
\end{array}$ & Comments & Reference \\
\hline Canada & $\begin{array}{l}2006 \text { to } \\
2007\end{array}$ & $\begin{array}{c}1000 \mathrm{~mL} \text { centrifuged } \\
14000 \mathrm{~g} \text { for } 20 \mathrm{~min} \\
\text { Culture }\end{array}$ & $\begin{array}{c}49.0 \% \\
(377 / 769)\end{array}$ & $\begin{array}{l}\text { 4.0E+02 MPN } \\
\text { (median) }\end{array}$ & $\begin{array}{c}\text { C. jejuni, } C \text {. } \\
\text { coli and } C \text {. lari } \\
\text { occurred in } \\
45 \%, 34 \% \text { and } \\
19 \% \text { of all } \\
\text { Campylobacter } \\
\text { positive } \\
\text { samples, } \\
\text { respectively }\end{array}$ & Khan et al., 2014 \\
\hline $\begin{array}{l}\text { Canada } \\
\text { (British } \\
\text { Columbia) }\end{array}$ & $\begin{array}{l}2004 \text { to } \\
2006\end{array}$ & $\begin{array}{l}500 \mathrm{~mL} \\
\text { Culture }\end{array}$ & $\begin{array}{c}43.0 \% \\
(80 / 186)\end{array}$ & $\mathrm{NR}^{\mathrm{e}}$ & $\begin{array}{l}93.4 \% \text { and } \\
7.9 \% \text { of } \\
\text { positive } \\
\text { samples } \\
\text { contained } C \text {. } \\
\text { jejuni and } C \text {. } \\
\text { coli, } \\
\text { respectively }\end{array}$ & Jokinen et al., 2010 \\
\hline $\begin{array}{l}\text { Canada } \\
\text { (Southern } \\
\text { Alberta) }\end{array}$ & $\begin{array}{c}2005 \text { to } \\
2007\end{array}$ & $\begin{array}{l}500 \mathrm{~mL} \\
\text { Culture } \\
\text { RIVER }\end{array}$ & $\begin{array}{c}26.6 \% \\
(91 / 342)\end{array}$ & NR & & Jokinen et al., 2012 \\
\hline \multirow{2}{*}{$\begin{array}{l}\text { Canada } \\
\text { (Waterloo) }\end{array}$} & \multirow{2}{*}{$\begin{array}{c}2005 \text { to } \\
2008\end{array}$} & $\begin{array}{l}100 \mathrm{~mL} \\
\text { qPCR } \\
\text { RIVER }\end{array}$ & $\begin{array}{c}69.8 \% \\
(275 / 394)\end{array}$ & $\begin{array}{c}\text { 5.5E+01 Cells } \\
\text { (median) } \\
(<1.0 \mathrm{E}+02 \text { to } \\
1.3 \mathrm{E}+03 \text { Cells })\end{array}$ & & \multirow{2}{*}{ Van Dyke et al., 2010} \\
\hline & & $\begin{array}{l}1000 \mathrm{~mL} \\
\text { Culture } \\
\text { RIVER }\end{array}$ & $\begin{array}{c}12.8 \% \\
(44 / 344)\end{array}$ & NR & $\begin{array}{c}\text { Culture results } \\
\text { only } \\
\text { qualitative }\end{array}$ & \\
\hline Finland & $\begin{array}{l}2006 \text { to } \\
2007\end{array}$ & $\begin{array}{c}\text { 10, } 100 \text { and } 1000 \mathrm{~mL} \\
\text { Culture } \\
\text { RECREATIONAL } \\
\text { WATER }\end{array}$ & $\begin{array}{l}58.0 \% \\
(29 / 50)\end{array}$ & $\begin{array}{l}\text { 5.0E+01 CFU } \\
\text { (median) } \\
(<1.0 \mathrm{E}+00 \text { to } \\
1.0 \mathrm{E}+02 \mathrm{CFU})\end{array}$ & $\begin{array}{c}\text { C. jejuni, C. } \\
\text { coli, C. lari } \\
\text { and } \\
\text { unidentified } \\
\text { Campylobacter } \\
\text { spp. isolates } \\
\text { found }\end{array}$ & Hokajärvi et al., 2013 \\
\hline $\begin{array}{l}\text { Germany } \\
\text { (North-Rhine } \\
\text { Westphalia) }\end{array}$ & NA & $\begin{array}{c}100 \mathrm{~mL}, 10 \mathrm{ml} \text { and } 1 \\
\text { ml } \\
\text { Culture } \\
\text { RIVER }\end{array}$ & $\begin{array}{c}86 \% \\
(87 / 101)\end{array}$ & 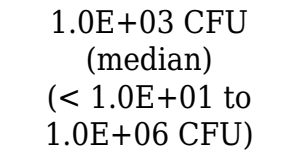 & & $\begin{array}{l}\text { Rechenburg and } \\
\text { Kistemann, } 2009\end{array}$ \\
\hline $\begin{array}{l}\text { Germany } \\
\text { (Weisse } \\
\text { Elster) }\end{array}$ & NA & $\begin{array}{l}\text { NR } \\
\text { Culture } \\
\text { RIVER }\end{array}$ & $82.1 \%$ & $\begin{array}{c}\text { From }<1.0 \mathrm{E}+02 \text { to } \\
>2.4 \mathrm{E}+03 \mathrm{CFU}\end{array}$ & $\begin{array}{c}\text { Species } \\
\text { identified: } C \text {. } \\
\text { jejuni }(92.2 \%), \\
\text { C. coli }(7.8 \%),\end{array}$ & $\begin{array}{c}\text { Stelzer and Jacob, } \\
1991\end{array}$ \\
\hline Greece & $\begin{array}{c}1990 \text { to } \\
1991\end{array}$ & $\begin{array}{l}100 \mathrm{~mL} \\
\text { Culture (without } \\
\text { enrichment) }\end{array}$ & $\begin{array}{c}16.3 \% \\
(14 / 86)\end{array}$ & NR & $\begin{array}{l}\text { For } C . \\
\text { jejuni only }\end{array}$ & $\begin{array}{c}\text { Arvanitidou et al., } \\
1995\end{array}$ \\
\hline $\begin{array}{l}\text { New } \\
\text { Zealand }\end{array}$ & NA & $\begin{array}{c}500 \mathrm{~mL}, 100 \mathrm{~mL} \text { and } \\
10 \mathrm{~mL} \\
\text { Culture } \\
\text { RIVER }\end{array}$ & $\begin{array}{c}60 \% \\
(18 / 30)\end{array}$ & $\begin{array}{c}\text { 1.8E+00 MPN } \\
\text { (median) } \\
(<1.2 \mathrm{E}+00 \text { to } \\
>1.1 \mathrm{E}+02 \mathrm{MPN})\end{array}$ & & Savill et al., 2001 \\
\hline
\end{tabular}




\begin{tabular}{|c|c|c|c|c|c|c|}
\hline Area & $\begin{array}{l}\text { Period of } \\
\text { study }\end{array}$ & $\begin{array}{l}\text { Sample Volume/ } \\
\text { Method } \\
\text { MATRIX }\end{array}$ & $\begin{array}{l}\text { Percent } \\
\text { Positive } \\
\text { (\# of } \\
\text { samples) }\end{array}$ & $\begin{array}{c}\text { Concentrations } \\
\text { Average } \\
\text { (Range) }^{\text {Range }} \\
\text { MPN }^{\mathrm{b}}, \mathrm{CFU}^{\mathrm{c}} \text { or } \\
\text { Cells }^{\mathrm{d}} / \mathrm{L}\end{array}$ & Comments & Reference \\
\hline $\begin{array}{l}\text { Northern } \\
\text { Ireland }\end{array}$ & NA & $\begin{array}{l}400 \mathrm{~mL} \\
\text { PCR } \\
\text { RIVER }\end{array}$ & $\begin{array}{c}0 \% \\
(0 / 17)\end{array}$ & BDL & $\begin{array}{c}\text { All samples } \\
\text { below the } \\
\text { detection limit }\end{array}$ & Moore et al., 2001 \\
\hline $\begin{array}{l}\text { Norway } \\
\text { (Oslo) }\end{array}$ & $\begin{array}{c}1986 \text { to } \\
1987\end{array}$ & $\begin{array}{l}3 \times 100 \mathrm{~mL} \\
\text { Culture } \\
\text { RIVER }\end{array}$ & $\begin{array}{l}43.8 \% \\
(42 / 96)\end{array}$ & NR & & Brennhovd et al., 1992 \\
\hline $\begin{array}{l}\text { Norway } \\
\text { (Telemark } \\
\text { County) }\end{array}$ & 1999 & $\begin{array}{l}100 \mathrm{Ml} \\
\text { Culture } \\
\text { RIVER }\end{array}$ & $\begin{array}{c}53.3 \% \\
(32 / 60)\end{array}$ & NR & $\begin{array}{c}\text { Isolates } \\
\text { identified as } C \text {. } \\
\text { coli }(44 \%), C \text {. } \\
\text { jejuni }(34.6 \%), \\
\text { C. lari }(14.7 \%) \\
\text { and not- } \\
\text { classified } \\
(6.7 \%) .\end{array}$ & Rosef et al., 2001 \\
\hline $\begin{array}{l}\text { Poland } \\
\text { (Western } \\
\text { Pomerania) }\end{array}$ & $\begin{array}{l}1998 \text { to } \\
1999\end{array}$ & $\begin{array}{c}10 \mathrm{~mL}, 1 \mathrm{~mL} \text { and } 0.1 \\
\mathrm{~mL} \\
\text { Culture } \\
\text { RIVER }\end{array}$ & $\begin{array}{c}19.7 \% \\
(29 / 147)\end{array}$ & $<1.0 \mathrm{E}+04 \mathrm{CFU}$ & $\begin{array}{c}\text { Species } \\
\text { identified: } C \text {. } \\
\text { jejuni ssp. } \\
\text { jejuni } 1 \\
(18.1 \%), C . \\
\text { jejuni ssp. } \\
\text { doylei } \\
(7.2 \%), C . \text { coli } \\
(4.8 \%), \text { C. lari } \\
(3.6 \%) \text { and } C \text {. } \\
\text { sputorum } \\
\text { ssp. fecalis } \\
\text { (3.6\%) }\end{array}$ & $\begin{array}{l}\text { Daczkowska-Kozon } \\
\text { and Brzostek- } \\
\text { Nowakowska, } 2001\end{array}$ \\
\hline $\begin{array}{l}\text { Spain } \\
\text { (Catalonia) }\end{array}$ & $\begin{array}{l}2004 \text { to } \\
2006\end{array}$ & $\begin{array}{l}1 \text { to } 1000 \mathrm{~mL} \text {, } \\
\text { centrifugation at } \\
7700 \mathrm{~g} \text { for } 20 \mathrm{~min} \\
\text { Culture } \\
\text { RIVER }\end{array}$ & $\begin{array}{l}81.8 \% \\
(45 / 55)\end{array}$ & $\begin{array}{c}\text { 1.3E+01 MPN } \\
\text { (geomean) } \\
(<4.0 \mathrm{E}-01 \text { to } \\
1.1 \mathrm{E}+04 \mathrm{MPN})\end{array}$ & & $\begin{array}{l}\text { Rodriguez and Araujo, } \\
2010\end{array}$ \\
\hline Taiwan & $\begin{array}{l}2007 \text { to } \\
2008\end{array}$ & $\begin{array}{l}1000 \mathrm{~mL} \\
\text { Culture } \\
\text { RIVER }\end{array}$ & $\begin{array}{l}2.7 \% \\
(2 / 75)\end{array}$ & NR & $\begin{array}{c}\text { Isolates } \\
\text { identified as } C . \\
\text { jejuni }\end{array}$ & Hu and Kuo, 2011 \\
\hline $\begin{array}{l}\text { The } \\
\text { Netherlands } \\
\text { (Gelderland) }\end{array}$ & $\begin{array}{l}1991 \text { to } \\
1993\end{array}$ & $\begin{array}{c}\text { NR } \\
\text { Culture } \\
\text { RIVER }\end{array}$ & $\begin{array}{l}69.4 \% \\
(25 / 36)\end{array}$ & $\begin{array}{c}1.7 \mathrm{E}+02 \mathrm{MPN} \\
(3.2 \mathrm{E}+01 \text { to } 1.6 \mathrm{E}+04 \\
\text { MPN })\end{array}$ & & Koenraad et al., 1994 \\
\hline $\begin{array}{l}\text { UK } \\
\text { (Lancashire) }\end{array}$ & $\begin{array}{l}1982 \text { to } \\
1983\end{array}$ & $\begin{array}{l}500 \mathrm{~mL} \\
\text { Culture } \\
\text { RIVER }\end{array}$ & $\begin{array}{c}43 \% \\
(134 / 312)\end{array}$ & $\begin{array}{l}<1.0 \mathrm{E}+02 \text { to } \\
2.3 \mathrm{E}+03 \mathrm{CFU}\end{array}$ & $\begin{array}{c}\text { Identified } \\
\text { species: } C \text {. } \\
\text { jejuni, } C . \text { coli, } \\
\text { C. lari }\end{array}$ & Bolton et al., 1987 \\
\hline $\begin{array}{l}\text { USA } \\
\text { (Georgia) }\end{array}$ & $\begin{array}{l}2003 \text { to } \\
2004\end{array}$ & $\begin{array}{c}0.1 \mathrm{~mL} \\
\text { Culture (without } \\
\text { enrichment) }\end{array}$ & $\begin{array}{l}59.5 \% \\
(44 / 74)\end{array}$ & $\begin{array}{l}\text { 4.6E+04 CFU } \\
(<1.0 \mathrm{E}+04 \text { to } \\
6.0 \mathrm{E}+05 \mathrm{CFU})\end{array}$ & & Vereen et al., 2007 \\
\hline $\begin{array}{l}\text { USA } \\
\text { (Pensacola, } \\
\text { Florida) }\end{array}$ & $\begin{array}{c}2008 \text { to } \\
2009\end{array}$ & $\begin{array}{l}500 \mathrm{~mL} \\
\text { qPCR }\end{array}$ & $\begin{array}{l}31.3 \% \\
(10 / 32)\end{array}$ & $\begin{array}{c}\text { 3.3E }+05 \text { Cells/L } \\
\text { (mean of +ve samples } \\
\text { only) } \\
(<1.0 \mathrm{E}+02 \text { to } \\
4.6 \mathrm{E}+06 \text { Cells } / \mathrm{L})\end{array}$ & $\begin{array}{l}\text { Results per } \\
\text { sites } \\
\text { (not per } \\
\text { samples) }\end{array}$ & Hellein et al., 2011 \\
\hline
\end{tabular}

${ }^{a}$ Undescribed surface water unless matrix specified; ${ }^{b} \mathrm{MPN}$ : Most probable number; ${ }^{\mathrm{c}} \mathrm{CFU}$ : Colony forming units; ${ }^{\mathrm{d}}$ Quantification was based on a standard curve constructed relating the number of bacterial cells to the cycle threshold (CT) of qPCR for known cell numbers of target bacteria determined by epifluorescent microscopy or culture; ${ }^{e}$ NR: Not reported. 
Noting the bias of culture methods to detect $C$. jejuni and $C$. coli, $C$. jejuni has been the species identified most frequently from surface waters (Thomas et al., 1999a), yet C. coli and C. lari are also commonly reported (Thomas et al., 1999a; Denis et al., 2011 Hokajärvi et al., 2013), associate with the presence of agricultural runoff or large flocks of waterfowl (Bolton et al., 1987; Obiri-Danso and Jones, 1999). In a study in Ontario, Canada, $73 \%$ of isolates from the samples of waterfowl feces $(n=15$ out of a total of
52 samples) were identified as $C$. jejuni, $13 \%$ were $C$. coli and 27\% C. lari (Van Dyke et al., 2010). By using gene detection after enrichment, it has been noted that the variety of Campylobacter species in watersheds is even broader, including $C$. consicus, $C$. gracilis, $C$. hyointestinalis, $C$. helveticus among others in addition to $C$. jejuni, $C$. coli and $C$. lari detected using culturing (Table 4 ) (Tambalo et al., 2016).

Table 4. Occurrence and distribution in water of Campylobacter species in Canadian (Saskatchewan) and French studies

Percent Positive
(\# of Samples)

Canada study; $200 \mathrm{ml}$ sample volume with culture and PCR after enrichment (2009 to 2013) (Source: Tambalo et al., 2016)

Campylobacter spp.

$38.7 \%$

C. coli

$(101 / 261)$

C. consicus

$11 \%$

C. curvus

$11 \%$

C. curvus

(10/93)

C. fetus

$1 \%$

$0 \%$

C. gracilis

$(0 / 93)$

C. helveticus

$5 \%$

C. hyointestinalis

C. jejuni

C. lari

C. mucosalis

C. rectus

C. spurotum

C. upsaliensis

French study (Brittany); $500 \mathrm{ml}$ sample volume of river water using culture (2006) (Source: Denis et al., 2011)

Campylobacter spp.

$\begin{array}{lc}\text { C. jejuni } & 33.3 \% \\ \text { C. coli } & (20 / 60) \\ & 16.7 \% \\ \text { C. lari } & (10 / 60) \\ & 5.0 \% \\ & (3 / 60)\end{array}$




\subsubsection{Groundwaters}

Campylobacter spp. are absent in groundwater not influenced by surface water, but many groundwaters may be contaminated during events, such as after flooding, hence the general need for disinfection. The majority of the Campylobacter outbreaks have been linked to relatively small groundwater works without adequate disinfection (Pitkänen, 2013; Guzman-Herrador et al., 2015). In some regions the occurrence of Campylobacter spp. in groundwater may be continuous as reported from wells in Canterbury, New Zealand, where Campylobacter spp. was detected in $12 \%(16 / 135)$ of the wells associated with intensive dairying combined with border strip irrigation, of which 11 samples out of 135 contained $C$. jejuni (8.1\%) and the Campylobacter counts varied from $<0.6$ to $3.1 \mathrm{MPN} / \mathrm{L}$ (Close et al., 2008). In another study from shallow groundwater aquifers in New Zealand, low counts of Campylobacter spp. were detected in $75 \%$ of samples $(\mathrm{n}=18$; Savill et al., 2001).

\subsubsection{Drinking waters}

Drinking water is a common vehicle reported for Campylobacter outbreaks (Frost, 2001) that may affect thousands of individuals at the same time (Miller and Mandrell, 2005), but generally outbreaks result from smaller supplies and affect fewer people (Pitkänen, 2013; Guzman-Herrador et al., 2015). Waterborne Campylobacter outbreaks probably remain under-reported in many countries, due to the lack of specific notification system or testing. The majority of reported outbreaks have occurred in Nordic countries (Hänninen et al., 2003; Pitkänen, 2013; Guzman-Herrador et al., 2015).

The contribution of drinking water to the burden of sporadic Campylobacter infections may be significantly underestimated. It is particularly difficult to recognize the association with water when private wells and untreated surface water is used as drinking water (Kapperud et al., 2003; Schönberg-Norio et al., 2004; Olson et al., 2008). For example, in Norway (Brennhovd et al., 1992) and Finland (Pitkänen et al., 2015), no Campylobacter spp. were recovered from water samples, but this is not always the case. Positive recoveries have been reported for Northern Ireland, 2.2\% (2/91) drinking water from domestic household taps were PCR positive for Campylobacter spp. (Moore et al., 2001), and in New Zealand, 29.2\% (7/24) of drinking water samples from centralized water supply were reported to be Campylobacter spp. positive (Savill et al., 2001). Also, 21\% (5/24) of household taps fed from rainwater tanks in Southeast Queensland, Australia contained 5.0 to $1.0 \times 10^{2}$ Campylobacter cells/L when assayed as 16S rRNA gene copies (Ahmed et al., 2012). In all of these detections, however, the infection risk to the public is only of potential concern as the Campylobacter counts detected were presumably low, not necessarily viable cells nor genotypes of human-infective species, like C. lari (Savill et al., 2001).

\subsubsection{Seawaters}

C. jejuni has also been detected in $2 \%$ of the sea water samples examined in Greece $(n=200)$ and represented the only Campylobacter species identified in the study (Arvanitidou et al., 1995). In Catalonia, Spain, Campylobacter spp. were absent from seawater samples $(\mathrm{n}=8)$ but Campylobacter spp. numbers below $5.0 \times 10^{2}$ MPN/L were detected in $78 \%$ of marsh water samples $(\mathrm{n}=9)$ from the same area (Rodriguez and Araujo, 2010). In Northern Ireland, Campylobacter spp. was absent from seawater samples $(n=6)$ but were detected using a PCR method in $4.3 \%$ of the estuary lough water samples from protected bays ( $n=23$; Moore et al., 2001). The presence of Campylobacter spp. is clearly sampling site dependent, as was seen in a Polish study where Campylobacter spp. were confirmed in $19.7 \%$ of the river water sampling sites nearby the contamination sources, but only $5.6 \%(3 / 54)$ of the lagoon and none of the 20 marine bay water samples (Daczkowska-Kozon and Brzostek-Nowakowska, 2001). The formation of VBNC cells in the saline environments may contribute to the low prevalence of Campylobacter spp. in seawater, when culture-based detection is used (Jackson et al., 2009; Gin and Goh, 2013).

\subsubsection{Soil and sediments}

Manure spreading operations are known to spread Campylobacter spp. to agricultural fields, and grazing livestock deposit Campylobacter spp. in their manure on pastures (Brown et al., 2004). The extent of wildlife feces in spreading Campylobacter spp. into terrestrial forest soils is less known.

Intertidal sediments are known reservoirs of Campylobacter spp. as reported from EU bathing sites in North West England where urease positive thermophilic campylobacters (UPTC) and C. lari were detected (ObiriDanso et al., 2001).

\subsubsection{Irrigation water and on crops}

Campylobacter spp. are commonly present in natural water systems (rivers, lakes, ponds) and their presence needs to be considered when natural water is used for irrigation (for occurrence in environmental water see Section 2.2.5) (Banting et al., 2016; Gu et al., 2013).

Agricultural application of raw sludge or anaerobically digested biosolids to arable land has long been recognized as a Campylobacter source to horticultural produce (Koenraad, 1997; Park and Sanders, 1992).

\subsubsection{Fish and shellfish}

There are no reports about Campylobacter spp. in fish, but shellfish harvested from fecally contaminated waters frequently contain Campylobacter spp. (Wilson and Moore, 1996). However, in the Campylobacter-positive shellfish samples, most were other species than the common human pathogens ( $C$. jejuni or $C$. coli), such as $C$. lari variants (Debruyne et al., 2009). 


\subsubsection{Air}

Airborne transmission of campylobacteriosis is not considered significant for Campylobacter spp., which are oxygen intolerant bacteria causing infection through the fecal-oral route. However, flies are common carriers of Campylobacter spp. especially in conditions where sanitation and excreta disposal is underdeveloped (Khalil et al., 1994).

\subsection{Persistence}

Campylobacter spp. isolated from the environment are likely to have originated from fresh fecal material. Campylobacter spp. are not expected to regrow in the environment since they are considered unable to multiply outside the intestines of warm-blooded host animals and birds (Jones, 2001). Nonetheless, laboratory studies indicate the potential for $C$. jejuni to grow within soil/water amoebae (reviewed within Vaerewijck et al., 2014). C. jejuni survives at $4{ }^{\circ} \mathrm{C}$ in moist, sun-sheltered environments (Bolton et al., 1987; Obiri-Danso and Jones, 1999; Kärenlampi and Hänninen, 2004), but is readily killed by temperatures reached in pasteurization, cooking, and frying
(Habib et al., 2010). Under UK field conditions Campylobacter spp. survives in livestock manure slurries for 32 days, but only 2 to 4 days in solid manure heaps in temperatures greater that $55^{\circ} \mathrm{C}$ (Nicholson et al., 2005). Maximum survival periods following the land spreading of manure and slurry varied from four days to the more than 32 days with some indication of longer survival in clay loam grassland than in sandy arable soil (Nicholson et al., 2005). An in vitro study also showed that the survival of $C$. coli in swine manure was for at least 25 days at $+4^{\circ} \mathrm{C}$ but decreased to a few days at $+22^{\circ} \mathrm{C}$ (Bui et al., 2011).

Table 5, Appendix A and Appendix B summarize the available Campylobacter spp. persistence data in different water matrices. Different survival characteristics of the Campylobacter spp. under environmental conditions may influence the diversity of different campylobacters (Korhonen and Martikainen 1991; Thomas et al., 1999b). For example, $C$. lari can survive better in aquatic environments than $C$. jejuni and $C$. coli (Obiri-Danso et al., 2001), and culturable $C$. jejuni survive longer than $C$. coli in lake water (Korhonen and Martikainen, 1991). Furthermore, $C$. coli and $C$. upsaliensis have demonstrated comparable survival characteristics (Thomas et al., 1999b).

Table 5. Persistence in manure, river water and seawater

\begin{tabular}{|c|c|c|c|c|c|c|c|c|}
\hline Area & $\begin{array}{c}\text { Bacterial } \\
\text { Species }\end{array}$ & Matrix & $\begin{array}{c}\text { Initial } \\
\text { Number } \\
\text { (CFU/ml) }\end{array}$ & $\begin{array}{c}\text { Model } \\
\text { Equation }\end{array}$ & $\begin{array}{l}\text { T90 } \\
\text { Days }\end{array}$ & $\begin{array}{c}\text { Temperature } \\
\left({ }^{\circ} \mathrm{C}\right)\end{array}$ & $\begin{array}{c}\text { Other } \\
\text { Experimental } \\
\text { Conditions }\end{array}$ & Reference \\
\hline \multirow{6}{*}{$\begin{array}{l}\text { New } \\
\text { Zealand } \\
\text { (Lincoln) }\end{array}$} & $\begin{array}{l}\text { C. jejuni } \\
\text { (mixture of } \\
\text { strains) }\end{array}$ & $\begin{array}{l}\text { River } \\
\text { water }\end{array}$ & $1.1 \mathrm{E}+06$ & $\begin{array}{c}\mathrm{k}_{\mathrm{D}}^{\mathrm{a}}\left(\mathrm{h}^{-1}\right)= \\
0.028\end{array}$ & 3.4 & 14 & Dark, DO 8 to $9 \mathrm{ppm}$ & \multirow{6}{*}{$\begin{array}{l}\text { Sinton et } \\
\text { al., } 2007\end{array}$} \\
\hline & $\begin{array}{l}\text { C. jejuni } \\
\text { (mixture of } \\
\text { strains) }\end{array}$ & $\begin{array}{l}\text { River } \\
\text { water }\end{array}$ & $1.1 \mathrm{E}+06$ & $\begin{array}{c}\mathrm{k}_{\mathrm{S}}^{\mathrm{b}}\left(\mathrm{m}^{2} \mathrm{MJ}^{-1}\right) \\
=2.74 \\
\mathrm{~ns}^{\mathrm{c}}=20.4\end{array}$ & 0.07 & 14 & $\begin{array}{l}\text { Sunlight, } \mathrm{S} 90^{\mathrm{d}}=1.65 \\
\mathrm{MJ} \mathrm{m}^{-2} \text {, winter, DO } 8 \text { to } \\
9 \mathrm{ppm}\end{array}$ & \\
\hline & $\begin{array}{l}\text { C. jejuni } \\
\text { (mixture of } \\
\text { strains) }\end{array}$ & $\begin{array}{l}\text { River } \\
\text { water }\end{array}$ & $1.1 \mathrm{E}+06$ & $\begin{array}{l}\mathrm{k}_{\mathrm{S}}\left(\mathrm{m}^{2} \mathrm{MJ}^{-1}\right) \\
=1.93 \\
\mathrm{~ns}=\mathrm{no} \\
\text { shoulder }\end{array}$ & 0.03 & 14 & $\begin{array}{l}\text { Sunlight, } \mathrm{S} 90=1.68 \mathrm{MJ} \\
\mathrm{m}^{-2} \text {, summer, DO } 8 \text { to } 9 \\
\text { ppm }\end{array}$ & \\
\hline & $\begin{array}{l}\text { C. jejuni } \\
\text { (mixture of } \\
\text { strains) }\end{array}$ & Seawater & $1.1 \mathrm{E}+06$ & $\begin{array}{c}\mathrm{k}_{\mathrm{D}}\left(\mathrm{h}^{-1}\right)= \\
0.066\end{array}$ & 1.5 & 14 & Dark, DO 8 to 9 ppm & \\
\hline & $\begin{array}{l}\text { C. jejuni } \\
\text { (mixture of } \\
\text { strains) }\end{array}$ & Seawater & $1.1 E+06$ & $\begin{array}{l}\mathrm{k}_{\mathrm{s}}\left(\mathrm{m}^{2} \mathrm{MJ}^{-1}\right) \\
=2.46 \\
\mathrm{~ns}=2.87\end{array}$ & 0.05 & 14 & $\begin{array}{c}\text { Sunlight, } \mathrm{S} 90=1.28 \mathrm{MJ} \\
\mathrm{m}^{-2} \text {, winter, DO } 8 \text { to } 9 \\
\text { ppm }\end{array}$ & \\
\hline & $\begin{array}{l}\text { C. jejuni } \\
\text { (mixture of } \\
\text { strains) }\end{array}$ & Seawater & $1.1 \mathrm{E}+06$ & $\begin{array}{l}\mathrm{k}_{\mathrm{S}}\left(\mathrm{m}^{2} \mathrm{MJ}^{-1}\right) \\
=3.99 \\
\mathrm{~ns}=13.3\end{array}$ & 0.03 & 14 & $\begin{array}{l}\text { Sunlight, } \mathrm{S} 90=1.38 \mathrm{MJ} \\
\mathrm{m}^{-2} \text {, summer, DO } 8 \text { to } 9 \\
\text { ppm }\end{array}$ & \\
\hline $\begin{array}{l}\text { United } \\
\text { Kingdom } \\
\text { (Northern } \\
\text { Ireland) }\end{array}$ & $\begin{array}{c}\text { C. jejuni } \\
\text { (B/86/4451 in } \\
\text { pasteurized } \\
\text { beef cattle } \\
\text { slurry) }\end{array}$ & $\begin{array}{l}\text { Manure } \\
\text { slurry }\end{array}$ & $1.0 \mathrm{E}+04$ & $\mathrm{NA}^{\mathrm{e}}$ & $\begin{array}{l}\text { Not } \\
\text { reached }\end{array}$ & $\begin{array}{l}4 \\
17\end{array}$ & pH 6.9 to 7.5 & $\begin{array}{l}\text { Kearney et } \\
\text { al., } 1993\end{array}$ \\
\hline $\begin{array}{l}\text { United } \\
\text { Kingdom } \\
\text { (Northern } \\
\text { Ireland) }\end{array}$ & $\begin{array}{c}\text { C. jejuni } \\
\text { (B/86/4451 in } \\
\text { pasteurized } \\
\text { beef cattle } \\
\text { slurry) }\end{array}$ & $\begin{array}{l}\text { Manure } \\
\text { slurry }\end{array}$ & $1.0 \mathrm{E}+05$ & $N A^{f}$ & $\begin{array}{c}\text { Not } \\
\text { reached }^{g}\end{array}$ & 35 & $\begin{array}{c}\text { Anaerobic digestion at } \\
35, \mathrm{pH} \text { increase from } \\
7.26 \text { to } 7.83 \text { during } 71 \\
\text { days. }\end{array}$ & $\begin{array}{l}\text { Kearney et } \\
\text { al., } 1993\end{array}$ \\
\hline
\end{tabular}


${ }^{\mathrm{a}} \mathrm{k}_{\mathrm{D}}$ : Dark inactivation coefficient; ${ }^{\mathrm{b}} \mathrm{k}_{\mathrm{S}}$ : Sunlight inactivation coefficient; ${ }^{\mathrm{c}} \mathrm{n}_{\mathrm{s}}$ : Shoulder constant; ${ }^{\mathrm{d}} \mathrm{S} 90$ : Insolation needed to achieve a $90 \%$ reduction in CFUs; ${ }^{\mathrm{e}} \mathrm{NA}$ : Not available, unchanged after 112 days at both temperatures; ${ }^{\mathrm{f}} \mathrm{NA}$ : Not available, no reduction detected; ${ }^{9}$ Estimate over 510 days (batch)/over 793 days (semi-continuous)

Campylobacter spp. do not carry many of the classic stress response mechanisms, but still employ a number of strategies enabling it to survive in the environment (Bronowski et al., 2014). However, the Campylobacter survival mechanisms in the environment are poorly understood and more data to predict the survival characteristics of Campylobacter spp. in water is needed (Gonzalez and Hänninen, 2012). The mechanisms may differ from those for most of the other enteric bacteria (Murphy et al., 2006). As with other enterics, C. jejuni enter into VBNC state under unfavorable conditions, however, what is different is that the size of cells is often reduced; with the shape of cells transformed from helical rods to cocci (Rollins and Colwell 1986; Jones 2001; Oliver 2005). In a recent study $C$. jejuni maintained the ability to adhere to intestinal cells after three weeks incubation in freshwater at $4^{\circ} \mathrm{C}$ indicating that the VBNC forms may retain their infectivity (Patrone et al., 2013). In artificial sea water at $4^{\circ} \mathrm{C}, C$. jejuni strains survived in the VBNC form through a period lasting from 138 to 152 days (Baffone et al., 2006). In drinking water at $4^{\circ} \mathrm{C}$, the origin of the strain and the culture conditions were an important factor determining campylobacter survival (Cools et al., 2003).

The key factors affecting the survival of Campylobacter spp. in aquatic environments include temperature, light, biotic interactions and concentrations of oxygen and nutrients (Thomas et al., 1999b). The survival of campylobacters is favoured by low temperature and the absence of sunlight as shown in the inactivation rate studied conducted in Catalonia, Spain (Rodríguez and Araujo 2012). Not only were campylobacters more susceptible to high light intensities than other enteric bacteria, but they appear to be unable to repair damage to DNA (Jones 2001). It has been reported that low numbers of indigenous microbiota favor the culturable detection of stressed Campylobacter cells (Korhonen and Martikainen, 1991). However, the viability of Campylobacter spp. in water systems is favoured by biofilms (Svensson et al., 2008) and by free-living amoebae harboring bacteria intracellularly (Snelling et al., 2005). The presence of protozoan grazers such as Acanthamoeba spp. has been reported to increase the survival of $C$. jejuni in vitro studies in water (Axelsson-Olsson et al., 2005).

\subsection{Reductions by Sanitation Management}

Overall, very little comparative data was available to identify surrogates for campylobacter inactivation by different sanitation management systems. Nonetheless, based on what is understood and summarized above (and in the chapter Using indicators to assess microbial treatment and disinfection efficacy), E. coli, enterococci and other fecal indicators may be reasonable surrogates. What is understood for campylobacters by sanitation systems is summarized below. In general, the absence of fecal indicator bacteria can be considered as a reliable proof of absence of Campylobacter spp. after the sanitation treatments. In oxygen-rich processes, Campylobacter spp. are presumably less persistent than fecal indicator bacteria. On the contrary, in anaerobic processes, the survival of Campylobacter spp. might be even better than fecal indicator bacteria (see section 3.1.5) and must be taken into consideration when evaluating the treatment efficiency.

\subsection{Excreta and Wastewater Treatment}

\subsubsection{Onsite Sanitation}

Campylobacter spp. might be present in effluents from on-site sand filters as shown by Kauppinen et al. (2014). The exact removal rates, however, remain unknown due to the semi-quantitative nature of the Campylobacter detection method and the inconsistent presence of Campylobacter spp. in the influent water.

3.1.1.1 Dry sanitation with inactivation by storage

Only little is known about Campylobacter spp. reductions by storage of human fecal material, but it is assumed survival would be similar as seen for animal manures. It is likely that Campylobacter survival in fecal material is dependent on available water $\left(\mathrm{a}_{\mathrm{w}}\right)$, as reported in studies related to foodstuffs (Fernandez et al., 1985). While other food processing pathogens have a number of mechanisms to withstand stresses (Burgess et al., 2016), Campylobacter spp. are considered uniquely sensitive to a number of environmental conditions and are generally less able to tolerate environmental stress than other foodborne pathogens (Park, 2002).

In experiments with swine manure in Denmark, $C$. coli remained viable for up to 24 days at $4{ }^{\circ} \mathrm{C}$, based on both culture and RT-qPCR results (Bui et al., 2011). Survival in swine feces was dependent on storage temperature, surviving one week at $15^{\circ} \mathrm{C}$ but only a few hours at $42^{\circ} \mathrm{C}$. Hence, Bui et al. (2011) suggests simply treated feces to temperature up to $42^{\circ} \mathrm{C}$ or even hotter for few hours before application on the agricultural soil to inactivate campylobacters; such as through solarization treatment (Simmons et al., 2013).

3.1.1.2 Pit latrines, vault toilets, dry toilets

Potential pathogen content of urine is low compared to feces (Höglund et al., 2002). For example, in a study of pathogens in source-diverted urine in South Africa, no Campylobacter was not detected in any of the urine samples (Bischel et al., 2015). Urine diversion enhances the dehydration of separately stored feces and thus, the $a_{w}$ decrease in the fecal material may result in a higher reduction in Campylobacter spp. numbers in dry toilets using urine diversion compared to combined systems.

3.1.1.3 Composting

Temperature and oxygen-content are considered major 
factors influencing Campylobacter spp. inactivation during sludge and manure composting, yet only limited data on reductions are available. For example, in France, aerated composting containing thermophilic phase $\left(50\right.$ to $\left.65^{\circ} \mathrm{C}\right)$ reduced the $C$. jejuni gene copy numbers from approximate $1.0 \times 10^{5}$ copies/g level to non-detect (Wery et al., 2008). In a pen manure $\left(20\right.$ to $50^{\circ} \mathrm{C}$ ) in Australia, the numbers of $C$. jejuni gene copies declined below the detection limit within one week (Klein et al., 2011), but a windrow compost configuration was not able to inactivate culturable $C$. coli from the sewage sludge in Sweden (Sahlström et al., 2004), possible due to uneven heating and poor mixing during the composting process.

3.1.1.4 Other residuals (solids) management: with the intention of reuse as fertilizer for agriculture/food, etc.

The low infectious dose of $C$. jejuni and its demonstrated ability to survive in the top $5 \mathrm{~cm}$ of soils for at least 25 days at $10^{\circ} \mathrm{C}$ must be noted prior to any reuse of solids that contain fecal matter (Ross \& Donnison, 2006). As a residual management strategies, the stockpiling of livestock bedding waste from animal pens to a secondary store, and storing them under conditions conducive for increased temperature is considered a simple and costeffective treatment for rapidly lowering levels of zoonotic agents, including Campylobacter spp. in solid farm wastes (Hutchison et al., 2005).

\subsubsection{Waste stabilization ponds}

When Sheludchenko et al. (2016) studied fecal microbes in remote and rural maturation ponds in Australia, they reported baffled maturation ponds operated more effectively for removal of presumptive Campylobacter spp. than other waste stabilization pond systems; as you would expect based on improved residence time control and reduced turbidity. In clear waters, rapid sunlight inactivation or at least the loss of culturability of $C$. jejuni is possible as detected in a survival study where waste stabilization pond effluent in seawater and river water was tested in New Zealand (Sinton et al., 2007).

3.1.2.1 Aerated lagoons

The efficiency of aerated lagoons to remove Campylobacter spp. remains unknown. Of other enteric bacteria in aerated wastewater lagoons, Salmonella reduction of approximately $0.91 \log _{10}$ and fecal coliform reduction of $1.4 \log _{10}$ has been reported in Tunisia (Ellouze et al., 2009). However, it is not known if these numbers are indicative for Campylobacter spp. reduction.
The VBNC state of $C$. jejuni cells, which are of a coccoid form, can be induced under oxygen-rich aerobic conditions (Oh et al., 2015). Thus, the ability of microaerophilic Campylobacter spp. to survive in aerated conditions may impact on Campylobacter spp. viability yet be missed if culture-based methods are used. However, the decimal reduction of $C$. jejuni HipO gene has been shown to be significantly faster in aerobic conditions as compared to anaerobic conditions in studies of thermophilic bio-waste sludge treatment in Austria (Wagner et al., 2009).

In addition to the oxygen content, also temperature affects Campylobacter culturability. This was seen for example in anaerobic swine manure lagoon samples in Mississippi, USA, where the rising lagoon water temperature was found to decrease viable Campylobacter counts (McLaughlin et al., 2012).

\subsubsection{Wetlands}

UK data demonstrated that wetlands constructed as horizontal reed beds may remove approximately $3 \log _{10}$ of the Campylobacter spp. from poultry manure wastewater (Duggan et al., 2001). While sequential and continuous loading had little effect on Campylobacter removal, a rising water level seemed to leach Campylobacter from the reed beds back into the effluent (Duggan et al., 2001). In Germany, Alexandrino et al. (2007) used qualitative PCR assay targeting $C$. jejuni, but non-detects for treating primary sewage by vertical and horizontal subsurface flow constructed wetlands hampered their estimate of removals.

\subsubsection{Wastewater treatment and resource recovery facilities}

As a common cause of gastroenteritis worldwide, Campylobacter spp. are often present in high numbers in untreated sewage (Table 2). While wastewater treatment generally reduces the number of campylobacters, combined sewer overflows (CSO) release untreated sewage to the receiving surface waters. It has been reported that during and after heavy rainfall when CSO is discharged, the rivers become highly contaminated with Campylobacter spp. and other kinds of pathogens (Rechenburg and Kistemann, 2009).

3.1.4.1 Primary/preliminary treatment

The reported $\log _{10}$ reduction of Campylobacter by primary treatment ranges from 0.7 to 1.4 (Table 6; Arimi et al., 1988; Höller, 1988). 
Table 6. Wastewater treatment reductions of Campylobacter

\begin{tabular}{|c|c|c|c|c|c|c|c|}
\hline Area & $\begin{array}{c}\text { Bacterial } \\
\text { Type }\end{array}$ & Treatment & $\begin{array}{c}\text { Description } \\
\text { of the } \\
\text { Treatment } \\
\text { Train } \\
\end{array}$ & $\begin{array}{c}\text { Concentrations } \\
\text { Influent } \\
\mathbf{M P N}^{\mathrm{a}} \text { or } \\
\mathrm{CFU}^{\mathrm{b}} / \mathbf{L} \\
\end{array}$ & $\begin{array}{c}\text { Concentrations } \\
\text { Effluent } \\
\text { MPN or CFU/L } \\
\end{array}$ & $\begin{array}{c}\text { Average } \\
\log _{10} \\
\text { Treatment } \\
\text { Reduction } \\
\end{array}$ & Reference \\
\hline $\begin{array}{l}\text { Australia } \\
\text { (Queensland) }\end{array}$ & $\begin{array}{l}\text { Presumptive } \\
\text { Campylobacter } \\
\text { spp. }\end{array}$ & $\begin{array}{l}\text { Wastewater } \\
\text { stabilization } \\
\text { ponds }\end{array}$ & $\begin{array}{l}\text { Maturation } \\
\text { pond with } \\
\text { baffles in the } \\
\text { subtropical } \\
\text { climate }\end{array}$ & 7.0E+02 CFU & $60 \mathrm{CFU}$ & 1.0 & $\begin{array}{l}\text { Sheludchenko } \\
\text { et al., } 2016\end{array}$ \\
\hline $\begin{array}{l}\text { Australia } \\
\text { (Queensland) }\end{array}$ & $\begin{array}{l}\text { Presumptive } \\
\text { Campylobacter } \\
\text { spp. }\end{array}$ & $\begin{array}{c}\text { Wastewater } \\
\text { stabilization } \\
\text { ponds }\end{array}$ & $\begin{array}{l}\text { Maturation } \\
\text { pond in the } \\
\text { tropical } \\
\text { climate }\end{array}$ & $9.6 \mathrm{E}+04 \mathrm{CFU}$ & 8.0E+04 CFU & 0.1 & $\begin{array}{l}\text { Sheludchenko } \\
\text { et al., } 2016\end{array}$ \\
\hline Finland (Siilinjärvi) & $\begin{array}{c}\text { Campylobacter } \\
\text { spp. }\end{array}$ & $\begin{array}{c}\text { Primary } \\
\text { flotation with } \\
\text { disinfection }\end{array}$ & $\begin{array}{l}\text { Peracetic acid } \\
\text { disinfection } \\
\text { PAA; } 3 \mathrm{mg} / \mathrm{L} \\
\text { after } \\
\text { dissolved air } \\
\text { flotation }\end{array}$ & $>5.0 \mathrm{CFU}$ & $<1.0 \mathrm{CFU}$ & $\begin{array}{l}>0.7 \text { to } \\
1.3\end{array}$ & $\begin{array}{l}\text { Pradhan et } \\
\text { al., } 2013\end{array}$ \\
\hline Germany(Kiel) & $\begin{array}{l}\text { Campylobacter } \\
\text { spp. }\end{array}$ & $\begin{array}{l}\text { Primary } \\
\text { treatment }\end{array}$ & 8 to $27^{\circ} \mathrm{C}$ & 3.7E+04 CFU & $1.5 \mathrm{E}+03 \mathrm{CFU}$ & 1.4 & Höller 1988 \\
\hline Germany (Kiel) & $\begin{array}{l}\text { Campylobacter } \\
\text { spp. }\end{array}$ & $\begin{array}{l}\text { Secondary } \\
\text { treatment }\end{array}$ & $\begin{array}{l}\text { Activated } \\
\text { sludge } \\
\text { (measured } \\
\text { after primary } \\
\text { treatment) }\end{array}$ & $1.5 \mathrm{E}+03 \mathrm{CFU}$ & $2.0 \mathrm{E}+02 \mathrm{CFU}$ & 0.9 & Höller 1988 \\
\hline \multirow{3}{*}{$\begin{array}{l}\text { Germany (North- } \\
\text { Rhine Westphalia) }\end{array}$} & \multirow{3}{*}{$\begin{array}{c}\text { Campylobacter } \\
\text { spp. }\end{array}$} & \multirow{3}{*}{$\begin{array}{l}\text { Secondary } \\
\text { treatment }\end{array}$} & $\begin{array}{l}\text { Activated } \\
\text { sludge } \\
1 \text { to } 7 \text { days } \\
\text { retention }\end{array}$ & \multirow{3}{*}{ 1.1E+06 CFU } & \multirow{3}{*}{ 1.0E+03 CFU } & $\begin{array}{l}1.41 \text { to } \\
2.26\end{array}$ & \multirow{3}{*}{$\begin{array}{c}\text { Rechenburg } \\
\text { and } \\
\text { Kistemann, } \\
2009\end{array}$} \\
\hline & & & $\begin{array}{l}\text { Activated } \\
\text { sludge } \\
\text { +trickling } \\
\text { filters } \\
1 \text { to } 7 \text { days } \\
\text { retention }\end{array}$ & & & $\begin{array}{c}3.01 \text { to } \\
3.51\end{array}$ & \\
\hline & & & $\begin{array}{l}\text { Tertiary } \\
\text { treatment } \\
\text { (sand } \\
\text { filtration) } \\
1 \text { day } \\
\text { retention }\end{array}$ & & & $\begin{array}{c}2.81 \text { to } \\
2.90\end{array}$ & \\
\hline $\begin{array}{l}\text { Germany (Weisse } \\
\text { Elster) }\end{array}$ & $\begin{array}{l}\text { Campylobacter } \\
\text { spp. }\end{array}$ & $\begin{array}{l}\text { Primary } \\
\text { treated } \\
\text { sewage }\end{array}$ & $\begin{array}{l}\text { Oxidation } \\
\text { pond }\end{array}$ & $15 \mathrm{CFU}$ & Non-detect & $\mathrm{NR}^{\mathrm{c}}$ & $\begin{array}{l}\text { Stelzer and } \\
\text { Jacob } 1991\end{array}$ \\
\hline $\begin{array}{l}\text { Germany (Weisse } \\
\text { Elster) }\end{array}$ & $\begin{array}{l}\text { Campylobacter } \\
\text { spp. }\end{array}$ & $\begin{array}{l}\text { Primary } \\
\text { treatment }\end{array}$ & $\begin{array}{c}4 \text { Emcher } \\
\text { tanks, flow } \\
1100 \mathrm{~m}^{3} / \text { day }\end{array}$ & $5.1 \mathrm{E}+02 \mathrm{CFU}$ & $15 \mathrm{CFU}$ & 1.5 & $\begin{array}{l}\text { Stelzer and } \\
\text { Jacob, } 1991\end{array}$ \\
\hline \multirow[t]{3}{*}{$\begin{array}{l}\text { Germany (Weisse } \\
\text { Elster) }\end{array}$} & \multirow[t]{3}{*}{$\begin{array}{c}\text { Campylobacter } \\
\text { spp. }\end{array}$} & \multirow[t]{3}{*}{ Secondary } & $\begin{array}{c}\text { Grit } \\
\text { separating } \\
\text { and } \\
\text { sedimentation } \\
\text { tanks }+ \\
\text { activated } \\
\text { sludge }\end{array}$ & $1.1 \mathrm{E}+04 \mathrm{CFU}$ & $5.8 \mathrm{E}+02 \mathrm{CFU}$ & 1.3 & \multirow[t]{3}{*}{$\begin{array}{l}\text { Stelzer and } \\
\text { Jacob, } 1991\end{array}$} \\
\hline & & & $\begin{array}{c}\text { Final } \\
\text { sedimentation }\end{array}$ & $5.8 \mathrm{E}+02 \mathrm{CFU}$ & $1.3 \mathrm{E}+03 \mathrm{CFU}$ & -0.2 & \\
\hline & & & $\begin{array}{c}\text { Total } \\
\text { reduction }\end{array}$ & $1.1 \mathrm{E}+04 \mathrm{CFU}$ & 1.3E+03 CFU & 0.9 & \\
\hline Italy (Bologna) & $\begin{array}{l}\text { Thermophilic } \\
\text { campylobacters }\end{array}$ & $\begin{array}{l}\text { Secondary } \\
\text { effluent } \\
\text { Chlorine } \\
\text { disinfection }\end{array}$ & $\begin{array}{c}2 \mathrm{ppm} \\
\text { chlorine } \\
\text { dioxide (2 } \\
\mathrm{mg} / \mathrm{L})\end{array}$ & $40 \mathrm{CFU}$ & $\begin{array}{c}\text { Non-detect }(<10 \\
\text { CFU) }\end{array}$ & $>0.6$ & $\begin{array}{c}\text { Stampi et al., } \\
1993\end{array}$ \\
\hline Italy (Bologna) & $\begin{array}{l}\text { Thermophilic } \\
\text { campylobacters }\end{array}$ & Secondary & $\begin{array}{l}\text { Oxygen based } \\
\text { activated } \\
\text { sludge }\end{array}$ & 1.7E+04 CFU & $50 \mathrm{CFU}$ & 2.4 & $\begin{array}{c}\text { Stampi et al. } \\
1993\end{array}$ \\
\hline
\end{tabular}




\begin{tabular}{|c|c|c|c|c|c|c|c|}
\hline Area & $\begin{array}{l}\text { Bacterial } \\
\text { Type }\end{array}$ & Treatment & $\begin{array}{c}\text { Description } \\
\text { of the } \\
\text { Treatment } \\
\text { Train } \\
\end{array}$ & $\begin{array}{c}\text { Concentrations } \\
\text { Influent } \\
\mathrm{MPN}^{\mathrm{a}} \text { or } \\
\mathrm{CFU}^{\mathrm{b}} / \mathrm{L} \\
\end{array}$ & $\begin{array}{c}\text { Concentrations } \\
\text { Effluent } \\
\text { MPN or CFU/L }\end{array}$ & $\begin{array}{c}\text { Average } \\
\log _{10} \\
\text { Treatment } \\
\text { Reduction } \\
\end{array}$ & Reference \\
\hline Italy (Bologna) & $\begin{array}{l}\text { Thermophilic } \\
\text { campylobacters }\end{array}$ & Secondary & $\begin{array}{c}\text { Activated } \\
\text { sludge } \\
\text { Secondary air } \\
\text { insufflation }\end{array}$ & 1.7E+04 CFU & $2.1 \mathrm{E}+02 \mathrm{CFU}$ & 2.0 & $\begin{array}{c}\text { Stampi et al. } \\
1993\end{array}$ \\
\hline Italy (Bologna) & $\begin{array}{l}\text { Thermophilic } \\
\text { campylobacters } \\
\text { (C. jejuni and } \\
\text { C. coli) }\end{array}$ & $\begin{array}{l}\text { Secondary } \\
\text { effluent } \\
\text { disinfection }\end{array}$ & $\begin{array}{c}3 \mathrm{ppm} \\
\text { chlorine } \\
\text { dioxide (3 } \\
\mathrm{mg} / \mathrm{L}), 15 \mathrm{~min}\end{array}$ & 3.0E+02 MPN & $\begin{array}{l}\text { non-detect } \\
(<10 \mathrm{MPN})\end{array}$ & $>1.5$ & $\begin{array}{c}\text { Stampi et al. } \\
1992\end{array}$ \\
\hline Italy (Bologna) & $\begin{array}{c}\text { Thermophilic } \\
\text { campylobacters } \\
\text { (C. jejuni and } \\
\text { C. coli) }\end{array}$ & Secondary & $\begin{array}{l}\text { Activated } \\
\text { sludge }\end{array}$ & 1.6E+04 MPN & 3.0E+02 MPN & 1.7 & $\begin{array}{c}\text { Stampi et al. } \\
1992\end{array}$ \\
\hline $\begin{array}{l}\text { The Netherlands } \\
\text { (Gelderland) }\end{array}$ & $\begin{array}{l}\text { Campylobacter } \\
\text { spp. }\end{array}$ & Secondary & $\begin{array}{c}\text { Activated } \\
\text { Sludge } \\
\text { 46,000 citizen } \\
\text { equivalents }\end{array}$ & $1.0 \mathrm{E}+04 \mathrm{MPN}$ & 1.0E+03 MPN & 1.0 & $\begin{array}{l}\text { Koenraad et } \\
\text { al } 1994\end{array}$ \\
\hline $\begin{array}{l}\text { The Netherlands } \\
\text { (Gelderland) }\end{array}$ & $\begin{array}{l}\text { Campylobacter } \\
\text { spp. }\end{array}$ & Secondary & $\begin{array}{l}\text { Trickling } \\
\text { filter }\end{array}$ & $\begin{array}{c}\text { Influent: } \\
\text { 4.0E+03 MPN }\end{array}$ & NR & 0.6 & $\begin{array}{l}\text { Koenraad et } \\
\text { al } 1994\end{array}$ \\
\hline $\begin{array}{l}\text { The Netherlands } \\
\text { (Gelderland) }\end{array}$ & $\begin{array}{l}\text { Campylobacter } \\
\text { spp. }\end{array}$ & Secondary & $\begin{array}{c}\text { Trickling } \\
\text { filter }+ \\
\text { chlorination } \\
\text { chlorine: } 15 \\
\text { min } 0.7 \text { to } 1.7 \\
\text { mg/L }\end{array}$ & $2.0 \mathrm{E}+03 \mathrm{MPN}$ & $\begin{array}{c}\text { non-detect }(<3.2 \\
\text { E+02 MPN })\end{array}$ & $>0.8$ & $\begin{array}{l}\text { Koenraad et } \\
\text { al } 1994\end{array}$ \\
\hline $\begin{array}{l}\text { United Kingdom } \\
\text { (Reading) }\end{array}$ & $\begin{array}{l}\text { Thermophilic } \\
\text { campylobacters }\end{array}$ & Secondary & $\begin{array}{c}\text { Trickling } \\
\text { filter } \\
\text { Measured } \\
\text { after primary } \\
\text { sedimentation } \\
5 \text { h retention }\end{array}$ & 3.9E+04 MPN & 1.7E+02 MPN & 2.4 & $\begin{array}{l}\text { Arimi et al. } \\
\quad 1988\end{array}$ \\
\hline $\begin{array}{l}\text { United Kingdom } \\
\text { (Reading) }\end{array}$ & $\begin{array}{c}\text { Thermophilic } \\
\text { campylobacters }\end{array}$ & $\begin{array}{c}\text { Primary } \\
\text { sedimentation }\end{array}$ & $2 \mathrm{~h}$ retention & $1.8 \mathrm{E}+05 \mathrm{MPN}$ & $3.9 \mathrm{E}+04 \mathrm{MPN}$ & 0.7 & $\begin{array}{l}\text { Arimi et al. } \\
1988\end{array}$ \\
\hline $\begin{array}{l}\text { United Kingdom } \\
\text { (Northamptonshire) }\end{array}$ & $\begin{array}{c}\text { Campylobacter } \\
\text { spp. }\end{array}$ & $\begin{array}{l}\text { Manure } \\
\text { slurry }\end{array}$ & $\begin{array}{l}\text { Constructed } \\
\text { wetlands } \\
\text { Experimental } \\
\text { reed beds } \\
\text { Manure } \\
\text { Slurry }\end{array}$ & $\begin{array}{l}1 \mathrm{E}+03 \text { to } 1 \\
\mathrm{E}+07 \mathrm{MPN}\end{array}$ & $\begin{array}{l}1 \mathrm{E}+03 \text { to } 1 \\
\mathrm{E}+04 \mathrm{MPN}\end{array}$ & 3.0 & $\begin{array}{c}\text { Duggan et al., } \\
2001\end{array}$ \\
\hline
\end{tabular}

${ }^{\mathrm{a}} \mathrm{MPN}$ : Most probable number, ${ }^{\mathrm{b}} \mathrm{CFU}$ : Colony forming units; ${ }^{\mathrm{C}} \mathrm{NR}$ : Not reported.

\subsubsection{Secondary treatment}

Even though Campylobacter cells are reduced by aerobic, biological treatment of wastewater, these processes do not completely eliminate Campylobacter spp. (Koenraad et al., 1997).

3.1.4.2.1 Trickling filters

Trickling filters have been reported to reduce the Campylobacter counts (Table 6; Arimi et al., 1988; Rechenburg and Kistemann, 2009), yet in other studies, only minimal reduction has been reported (Table 6; Koenraad et al., 1994); thus large numbers of Campylobacter spp. might be released into the environment daily from sewage treatment plants if no other treatment is used.

\subsection{Activated sludge}

In studies from late 1980 's, more than $0.8 \log _{10}$ reduction of culturable Campylobacter in secondary treatment (including the activated sludge process) were reported (Table 6; Höller, 1988; Stelzer and Jacob, 1991; Stampi et al., 1992; Koenraad et al., 1994).

More recent reports, often based on molecular detection of Campylobacter spp., show discrepancies in reduction and indicate the enhanced ability of this genus to persist and survive in different environments (as reviewed in Whiley et al., 2013). For example, Wéry et al. (2008) study in France using qPCR, concluded that $C$. jejuni VP1 
gene survived better during the activated sludge treatment compared to the E. coli lacZ gene. However, due to the lower copy number in the influent, they did not detect $C$. jejuni gene copies in the treated water while the $E$. coli genes were still quantifiable.

\subsection{Oxidation ditch}

No reports of Campylobacter spp. reduction by oxidation ditches were identified. It is presumable that the successful oxidation improves Campylobacter reduction. See discussion about the effect of oxygen-rich conditions on Campylobacter spp. viability in section 3.1.2.1 (aerated lagoons).

3.1.4.2.4 Membrane bioreactors

In studies reviewed by Hai et al. (2014), almost complete removal of bacteria by membrane bioreactors (MBR) was reported, whereas virus removal was inconsistent. Even though Campylobacter was not mentioned, it is presumable that a well-functioning MBR system is efficient in removing Campylobacter.

\subsubsection{Biosolids/sewage sludge treatment/anaerobic digestion/anoxic digestion}

Whiley et al. (2013) suggested in their review that oxygen intolerant Campylobacter spp. might survive even better than traditional fecal indicator bacteria during anaerobic digestion. Indeed, it has been observed that $C$. jejuni survives in a viable and culturable state during mesophilic anaerobic digestion $\left(35^{\circ} \mathrm{C}\right)$ and the estimated time required for $1 \log _{10}$ reduction was 793 days under those conditions (Kearney et al. 1993). Also in a study by Koenraad et al. (1994), campylobacters were isolated from $88 \%$ of secondary biosolids, with an average count $2.5 \times 10^{3}$ MPN/L ( $\mathrm{n}=30)$. Horan et al. (2004), using a culture-based methodology, observed no inactivation of $C$. jejuni within 22 days at $35^{\circ} \mathrm{C}$ in a primary sludge digester and only $0.4 \log _{10}$ reduction was observed after the secondary sludge digestion at $15^{\circ} \mathrm{C}$ for 14 days. Hence, anaerobic digestion appears to be a relatively poor treatment approach to reduce campylobacter numbers.

However, treatment conditions have a major impact on Campylobacter spp. reductions. The absence of campylobacters was noted when biosolids are digested aerobically (Betaieb and Jones, 1990; Stelzer and Jacob, 1991) and many reports have indicated that culturable Campylobacter spp. in sludge are eliminated by digestion processes (Jones et al., 1990; Stampi et al., 1999). In a Swedish study in 2000 to 2001, thermophilic anaerobic digestion at $55^{\circ} \mathrm{C}$, mesophilic anaerobic digestion at 34 to $42^{\circ} \mathrm{C}$, composting and sedimentation all seem to remove Campylobacter spp. from sewage sludge (Sahlström et al., 2004). The sanitation of sludge using composting was also demonstrated in a study from France, where the thermophilic phase of composting was capable of reducing the $C$. jejuni VP1 gene copy numbers from $3.9 \times 10^{5} / \mathrm{g}$ of compost wet weight to non-detectible (Wery et al., 2008).

After the digestion of dewatered biosolids, storage temperature plays an important role in further reducting
Campylobacter spp. Ahmed and Sorensen (1995) reported more than $4 \log _{10}$ reduction of culturable $C$. jejuni counts within a day at $50^{\circ} \mathrm{C}$ while only $2 \log _{10}$ reduction was observed within 62 days at $5^{\circ} \mathrm{C}$.

\subsubsection{Tertiary treatment post secondary}

When further removal of campylobacters is required to minimize human exposure, i.e. for wastewater reuse purposes, in close proximity of recreational areas or raw water intake sites for drinking water production (Levantesi et al., 2010), then various tertiary wastewater treatments options should be considered, as introduced below. 3.1.6.1 Lagooning

See 3.1.2.1.

3.1.6.2 Coagulation

The use of PIX $\left(\mathrm{FeCl}_{3}\right)$ and PAX $\left(\mathrm{AlCl}_{3}\right)$ coagulants was shown to efficiently reduce the microbial load in wastewater effluents in Finland (Pradhan et al., 2013). However, the reduction of Campylobacter spp. was not evaluated due to non-detects in the secondary treated influent.

3.1.6.3 Filtration

Slow sand filtration has long been used for drinking water purification. The removal efficiency of slow sand filtration has been studied at full-scale drinking waterworks in The Netherlands, where $3.4 \pm 0.6 \log _{10}$ reduction of Campylobacter spp. was reported (Hijnen et al., 2004).The culture counts of Campylobacter spp. may reduce in sand filtration more efficiently than E. coli counts (Hijnen et al., 2004). Sand filtration has more recently been used as a tertiary treatment option (Rechenburg and Kistemann, 2009), however, no campylobacter removal rates for this unit process for wastewater were identified.

\subsection{Membranes}

Microfiltration with a nominal porosity of 0.1 micron (meaning there are larger pores present but poorly defined) has a moderate efficacy in removing Campylobacter spp., while ultrafiltration and nanofiltration filters (with less than 0.05 micron pore sizes) as well as reverse osmosis are expected to provide very high removals of Campylobacter s p p.

(http://www.cdc.gov/healthywater/drinking/home-water-tre atment/household_water_treatment.html, accessed 29th June 2016). For example in Belgium, the ultrafiltration permeate contained no fecal bacteria (Levantesi et al., 2010). The real concern is with absolute membrane removal processes is the day-to-day performance, or ability to maintain integrity (see chapter Sewered System Technologies).

3.1.6.3.2 Mono, dual and tri media

No research reports were identified for these types of media. However, it is expected that Campylobacter spp. reductions in mono, dual and tri media follow the patterns observed using fecal indicator bacteria, especially E. coli. 


\subsubsection{Land treatment}

Managed aquifer recharge (MAR) with treated municipal wastewater is used for water storage and additional purification in water reuse processes. Levantesi et al. (2010) studied the counts of fecal indicators in MAR processes at three European sites. The aquifer characteristics and the quality of the injectant water both appear to affect the quality of recovered water. It is presumable that Campylobacter spp. are reduced while the water passes through the soil at least with the same efficiency as $E$. coli , but no data was identified to confirm this.

3.1.6.5 Other processes

None identified.

\subsection{Disinfection as a Tertiary (or Post Primary) Treatment}

\subsubsection{Chlorine, combined etc.}

Chemical disinfectants are applied at a concentration for a specified time to deliver what is known as the $\mathrm{Ct}$ (concentration $\mathrm{x}$ time), but many reports identified only provided concentration data. For example, tertiary treatment (disinfection) of treated wastewater at 1 to $3 \mathrm{mg} /$ $\mathrm{L}$ free chlorine was shown to reduce Campylobacter spp. counts below the culture method detection limit (Table 6; Stampi et al., 1992; Stampi et al., 1993; Koenraad et al., 1994). Based on the plate counting of bacteria, C. jejuni is generally considered more susceptible to chlorine than $E$. coli and thus the elimination of $E$. coli is considered adequate measure to confirm the absence of $C$. jejuni (Blaser et al., 1986). However, some caution is needed as it is well known that culture methods may seriously underestimate the $C$. jejuni (and $E$. coli) viable counts in chlorinated waters (Lehtola et al., 2006) and viable bacteria cells may remain inside protozoa under chlorine exposure (Snelling et al., 2005).

Alternative options to chlorine have been searched to fulfill the requirement of post-primary treatment disinfection without the hazards related to disinfection byproducts. For example, peracetic acid disinfection (PAA; 3 $\mathrm{mg} / \mathrm{L}$ ) after dissolved air flotation treatment have been shown to reduce the culturable Campylobacter spp. counts in wastewater effluent to below the detection limit (Pradhan et al., 2013).

\subsubsection{Ultraviolet}

UV disinfection can be effective against all waterborne pathogens if turbidity is sufficiently low (Hijnen et al., 2006). C. jejuni is considered more sensitive to UV compared to $E$. coli and the culturable cells of $C$. jejuni can be easily removed from water using UV. In clear waters (in sterile distilled water) at room temperature and when the occurrence of VBNC cells were not considered, a $3 \log _{10} C$. jejuni reduction may be been achieved with a fluence of 1.8 $\mathrm{mJ} \mathrm{cm}{ }^{-2}$ (Butler et al., 1987). The estimated required fluence for $4 \log _{10}$ reduction of Campylobacter spp. is $14 \mathrm{~mJ} \mathrm{~cm}{ }^{-2}$ (Hijnen et al., 2006). However, lower quality of the secondary effluent turbidity may hamper the efficiency of tertiary UV treatment at wastewater purification plants. Synergistic effects of PAA or $\mathrm{H}_{2} \mathrm{O}_{2}$ induced radical formation together with UV have been studied to achieve higher disinfection efficiency with more turbid wastewaters (Koivunen and Tanski, 2005).

\subsubsection{Natural processes}

It has been reported in purified (distilled) water that about two minutes under conditions of strong natural sunlight is enough for $1 \log _{10}$ reduction of $C$. jejuni plate counts (Boyle et al., 2008). In sanitation applications, the true reductions of viable Campylobacter spp. are presumably somewhat lower mainly due to the occurrence of VBNC cells and differential light penetration properties in wastewater-impacted natural waters. In fresh surface water contaminated by sewage effluent, a $1 \log _{10}$ reduction in $C$. jejuni took more than $82 \mathrm{~h}$ in the dark at $14^{\circ} \mathrm{C}$, while the same reduction was achieved in 1 to 2 hours in sunlight (Sinton et al., 2007).

In experimental dessication conditions, Campylobacter strains remained viable for 2 to $10 \mathrm{~h}$ (Fernandez et al., 1985). Based on studies in feces on pasture, temperature and diffused oxygen, rather than desiccation increased the inactivation of Campylobacter spp. (Sinton et al., 2007). 
Appendix A. Persistence data for Campylobacter in river water microcosms stored in the dark $^{\mathrm{a}}$

\begin{tabular}{|c|c|c|c|c|c|}
\hline Microorganism & $\begin{array}{c}\text { Initial } \\
\text { Concentration } \\
\mathrm{MPN}^{\mathbf{b}} / \mathbf{m l} \\
\end{array}$ & Time Stored (days) & $\begin{array}{c}\text { Final Concentration } \\
\left(\mathrm{MPN}^{\mathbf{b}} / \mathbf{m l}\right)\end{array}$ & $\begin{array}{c}\log 10 \\
\text { Reductions } \\
\text { /Day } \\
\end{array}$ & $\underset{\left({ }^{\circ} \mathrm{C}\right)}{\text { Temp }}$ \\
\hline \multirow{6}{*}{$\begin{array}{l}\text { Campylobacter } \\
\text { coli (DSMZ } \\
4689)\end{array}$} & \multirow{4}{*}{$\mathrm{R} 1^{\mathrm{C}}: 3.5 \mathrm{E}+06$} & 2.0 & $2.8 \mathrm{E}+04$ & 1.0 & \multirow{6}{*}{10} \\
\hline & & 3.0 & $4.6 \mathrm{E}+03$ & 1.0 & \\
\hline & & 4.0 & $4.6 \mathrm{E}+02$ & 1.0 & \\
\hline & & 1.0 & $4.6 \mathrm{E}+06$ & -0.1 & \\
\hline & \multirow[t]{2}{*}{$\mathrm{R}^{\mathrm{d}}: 3.5 \mathrm{E}+06$} & 3.0 & $6.4 \mathrm{E}+03$ & 0.9 & \\
\hline & & 4.0 & $4.6 \mathrm{E}+03$ & 0.7 & \\
\hline \multirow{8}{*}{$\begin{array}{l}\text { Campylobacter } \\
\text { coli (DSMZ } \\
4689)\end{array}$} & \multirow{5}{*}{$\mathrm{R} 1: 4.0 \mathrm{E}+04$} & 0.9 & $4.0 \mathrm{E}+03$ & 1.1 & \multirow{8}{*}{20} \\
\hline & & 1.9 & $4.3 \mathrm{E}+02$ & 1.0 & \\
\hline & & 2.8 & $1.1 \mathrm{E}+03$ & 0.6 & \\
\hline & & 4.3 & $4.6 \mathrm{E}+01$ & 0.7 & \\
\hline & & 0.9 & $4.0 \mathrm{E}+03$ & 1.1 & \\
\hline & \multirow{3}{*}{$\mathrm{R} 2: 4.0 \mathrm{E}+04$} & 1.9 & $2.3 \mathrm{E}+02$ & 1.2 & \\
\hline & & 2.8 & $2.4 \mathrm{E}+03$ & 0.4 & \\
\hline & & 4.3 & $1.1 \mathrm{E}+03$ & 0.4 & \\
\hline \multirow{6}{*}{$\begin{array}{l}\text { Campylobacter } \\
\text { coli (DSMZ } \\
4689)\end{array}$} & \multirow{6}{*}{$\mathrm{R} 2: 3.5 \mathrm{E}+06$} & 0.3 & $3.9 \mathrm{E}+04$ & 7.8 & \multirow{6}{*}{30} \\
\hline & & 1.0 & $4.0 \mathrm{E}+03$ & 2.9 & \\
\hline & & 2.0 & $<4.0 \mathrm{E}+01$ & $>2.5$ & \\
\hline & & 0.3 & $2.4 \mathrm{E}+05$ & 4.7 & \\
\hline & & 1.0 & $2.1 \mathrm{E}+03$ & 3.2 & \\
\hline & & 2.0 & $<4.0 \mathrm{E}+01$ & $>2.5$ & \\
\hline \multirow{4}{*}{$\begin{array}{l}\text { Campylobacter } \\
\text { coli } \\
\text { (environmental } \\
\text { strain MRA16 } \\
21 \text { ) }\end{array}$} & \multirow{2}{*}{$\mathrm{R} 1: 2.4 \mathrm{E}+07$} & 0.9 & $4.6 \mathrm{E}+06$ & 0.8 & \multirow{4}{*}{$\mathrm{NR}^{\mathrm{e}}$} \\
\hline & & 1.9 & $4.6 \mathrm{E}+06$ & 0.4 & \\
\hline & \multirow{2}{*}{$\mathrm{R} 2: 4.6 \mathrm{E}+06$} & 0.9 & $1.2 \mathrm{E}+06$ & 0.6 & \\
\hline & & 1.9 & $9.3 \mathrm{E}+04$ & 0.9 & \\
\hline \multirow{7}{*}{$\begin{array}{l}\text { Campylobacter } \\
\text { coli } \\
\text { (environmental } \\
\text { strain MRA16 } \\
21 \text { ) }\end{array}$} & \multirow{3}{*}{$\mathrm{R} 1: 2.4 \mathrm{E}+07$} & 0.9 & $4.6 \mathrm{E}+06$ & 0.8 & \multirow{7}{*}{20} \\
\hline & & 1.9 & $4.6 \mathrm{E}+06$ & 0.4 & \\
\hline & & 4.3 & $2.4 \mathrm{E}+02$ & 1.2 & \\
\hline & \multirow{4}{*}{$\mathrm{R} 2: 4.6 \mathrm{E}+06$} & 0.9 & $4.6 \mathrm{E}+06$ & 0.0 & \\
\hline & & 1.9 & $4.6 \mathrm{E}+06$ & 0.0 & \\
\hline & & 2.8 & $1.1 \mathrm{E}+04$ & 0.9 & \\
\hline & & 4.3 & $1.5 \mathrm{E}+02$ & 1.1 & \\
\hline \multirow{6}{*}{$\begin{array}{l}\text { Campylobacter } \\
\text { coli } \\
\text { (environmental } \\
\text { strain MRA16 } \\
21 \text { ) }\end{array}$} & & 1.9 & $1.1 \mathrm{E}+06$ & 0.7 & \multirow{6}{*}{30} \\
\hline & $\mathrm{R} 1: 2.4 \mathrm{E}+07$ & 2.8 & $7.5 \mathrm{E}+01$ & 1.9 & \\
\hline & & 4.3 & 2.3 & 1.7 & \\
\hline & & 1.9 & $4.6 \mathrm{E}+04$ & 1.0 & \\
\hline & $\mathrm{R} 2: 4.6 \mathrm{E}+06$ & 2.8 & $7.5 \mathrm{E}+02$ & 1.3 & \\
\hline & & 4.3 & 4.3 & 1.4 & \\
\hline
\end{tabular}




\begin{tabular}{|c|c|c|c|c|c|}
\hline Microorganism & $\begin{array}{c}\text { Initial } \\
\text { Concentration } \\
\mathrm{MPN}^{\mathbf{b}} / \mathbf{m l} \\
\end{array}$ & Time Stored (days) & $\begin{array}{c}\text { Final Concentration } \\
\left(\mathrm{MPN}^{\mathbf{b}} / \mathbf{m l}\right)\end{array}$ & $\begin{array}{c}\text { Log10 } \\
\text { Reductions } \\
\text { /Day } \\
\end{array}$ & $\underset{\left({ }^{\circ} \mathrm{C}\right)}{\text { Temp }}$ \\
\hline \multirow{16}{*}{$\begin{array}{l}\text { Campylobacter } \\
\text { jejuni (DSMZ } \\
4688 \text { ) }\end{array}$} & \multirow{8}{*}{$\mathrm{R} 1: 1.1 \mathrm{E}+07$} & 1.0 & $2.4 \mathrm{E}+06$ & 0.7 & \multirow{16}{*}{4} \\
\hline & & 2.0 & $2.4 \mathrm{E}+06$ & 0.3 & \\
\hline & & 4.0 & $4.6 \mathrm{E}+06$ & 0.1 & \\
\hline & & 8.0 & $1.1 \mathrm{E}+06$ & 0.1 & \\
\hline & & 10.0 & $1.1 \mathrm{E}+04$ & 0.3 & \\
\hline & & 16.0 & $2.4 \mathrm{E}+02$ & 0.3 & \\
\hline & & 19.0 & $1.1 \mathrm{E}+02$ & 0.3 & \\
\hline & & 23.0 & $4.6 \mathrm{E}+01$ & 0.2 & \\
\hline & \multirow{8}{*}{ R2: $1.1 \mathrm{E}+07$} & 1.0 & $1.1 \mathrm{E}+07$ & 0.0 & \\
\hline & & 2.0 & $1.5 \mathrm{E}+06$ & 0.4 & \\
\hline & & 4.0 & $2.4 \mathrm{E}+06$ & 0.2 & \\
\hline & & 8.0 & $2.4 \mathrm{E}+05$ & 0.2 & \\
\hline & & 10.0 & $1.5 \mathrm{E}+05$ & 0.2 & \\
\hline & & 16.0 & $4.6 \mathrm{E}+02$ & 0.3 & \\
\hline & & 19.0 & $1.1 \mathrm{E}+02$ & 0.3 & \\
\hline & & 23.0 & $1.1 \mathrm{E}+02$ & 0.2 & \\
\hline \multirow{20}{*}{$\begin{array}{l}\text { Campylobacter } \\
\text { jejuni (DSMZ } \\
4688)\end{array}$} & \multirow{11}{*}{$\mathrm{R} 1: 2.4 \mathrm{E}+06$} & 0.3 & $2.4 \mathrm{E}+07$ & -4.0 & \multirow{20}{*}{10} \\
\hline & & 1.1 & $>1.1 \mathrm{E}+06$ & $<0.3$ & \\
\hline & & 2.0 & $>1.1 \mathrm{E}+06$ & $<0.2$ & \\
\hline & & 3.3 & $1.1 \mathrm{E}+06$ & 0.1 & \\
\hline & & 4.9 & $1.1 \mathrm{E}+06$ & 0.1 & \\
\hline & & 6.9 & $2.4 \mathrm{E}+05$ & 0.1 & \\
\hline & & 8.8 & $2.4 \mathrm{E}+04$ & 0.2 & \\
\hline & & 12.1 & $4.3 \mathrm{E}+03$ & 0.2 & \\
\hline & & 14.1 & $4.6 \mathrm{E}+03$ & 0.2 & \\
\hline & & 16.0 & $2.1 \mathrm{E}+02$ & 0.3 & \\
\hline & & 0.3 & $4.6 \mathrm{E}+06$ & 0.0 & \\
\hline & \multirow{9}{*}{$\mathrm{R} 2: 4.6 \mathrm{E}+06$} & 1.1 & $4.6 \mathrm{E}+05$ & 0.9 & \\
\hline & & 2.0 & $1.1 \mathrm{E}+06$ & 0.3 & \\
\hline & & 3.3 & $1.1 \mathrm{E}+06$ & 0.2 & \\
\hline & & 4.9 & $1.1 \mathrm{E}+06$ & 0.1 & \\
\hline & & 6.9 & $9.3 E+04$ & 0.2 & \\
\hline & & 8.8 & $2.4 \mathrm{E}+04$ & 0.3 & \\
\hline & & 12.1 & $9.3 \mathrm{E}+02$ & 0.3 & \\
\hline & & 14.1 & $2.1 \mathrm{E}+02$ & 0.3 & \\
\hline & & 16.0 & $2.4 \mathrm{E}+02$ & 0.3 & \\
\hline
\end{tabular}




\begin{tabular}{|c|c|c|c|c|c|}
\hline Microorganism & $\begin{array}{c}\text { Initial } \\
\text { Concentration } \\
\mathrm{MPN}^{\mathbf{b}} / \mathrm{ml}\end{array}$ & Time Stored (days) & $\begin{array}{c}\text { Final Concentration } \\
\left(\mathrm{MPN}^{\mathbf{b}} / \mathbf{m l}\right)\end{array}$ & $\begin{array}{c}\log 1 \\
\text { Redugtions } \\
\text { /Day } \\
\end{array}$ & $\underset{\left({ }^{\circ} \mathrm{C}\right)}{\text { Temp }}$ \\
\hline \multirow{14}{*}{$\begin{array}{l}\text { Campylobacter } \\
\text { jejuni (DSMZ } \\
4688)\end{array}$} & \multirow{8}{*}{ R1: 5.9E+06 } & 1.0 & $4.6 \mathrm{E}+06$ & 0.1 & \multirow{14}{*}{20} \\
\hline & & 1.9 & $4.6 \mathrm{E}+06$ & 0.1 & \\
\hline & & 4.9 & $4.6 \mathrm{E}+04$ & 0.4 & \\
\hline & & 5.9 & $2.4 \mathrm{E}+04$ & 0.4 & \\
\hline & & 7.0 & $1.1 \mathrm{E}+03$ & 0.5 & \\
\hline & & 8.0 & $7.5 \mathrm{E}+01$ & 0.6 & \\
\hline & & 9.0 & 9 & 0.6 & \\
\hline & & 1.0 & $9.3 \mathrm{E}+06$ & -0.2 & \\
\hline & \multirow{6}{*}{$\mathrm{R} 2: 5.9 \mathrm{E}+06$} & 1.9 & $1.5 \mathrm{E}+06$ & 0.3 & \\
\hline & & 4.9 & $2.1 \mathrm{E}+06$ & 0.1 & \\
\hline & & 5.9 & $2.4 \mathrm{E}+03$ & 0.6 & \\
\hline & & 7.0 & $2.4 \mathrm{E}+02$ & 0.6 & \\
\hline & & 8.0 & $4.3 \mathrm{E}+01$ & 0.6 & \\
\hline & & 9.0 & $<3$ & $>0.7$ & \\
\hline \multirow{14}{*}{$\begin{array}{l}\text { Campylobacter } \\
\text { jejuni (DSMZ } \\
4688 \text { ) }\end{array}$} & \multirow{8}{*}{$\mathrm{R} 1: 1.1 \mathrm{E}+07$} & 0.3 & $1.5 \mathrm{E}+06$ & 3.5 & \multirow{14}{*}{30} \\
\hline & & 1.0 & $1.1 \mathrm{E}+06$ & 1.0 & \\
\hline & & 1.3 & $4.6 \mathrm{E}+05$ & 1.1 & \\
\hline & & 2.0 & $4.6 \mathrm{E}+04$ & 1.2 & \\
\hline & & 3.0 & $9.3 \mathrm{E}+02$ & 1.4 & \\
\hline & & 4.0 & $2.4 \mathrm{E}+01$ & 1.4 & \\
\hline & & 8.0 & 0.04 & 1.1 & \\
\hline & & 0.3 & $2.4 \mathrm{E}+06$ & 2.6 & \\
\hline & \multirow{6}{*}{$\mathrm{R} 2: 1.1 \mathrm{E}+07$} & 1.0 & $2.4 \mathrm{E}+05$ & 1.7 & \\
\hline & & 1.3 & $2.4 \mathrm{E}+05$ & 1.3 & \\
\hline & & 2.0 & $4.6 \mathrm{E}+04$ & 1.2 & \\
\hline & & 3.0 & $4.3 \mathrm{E}+02$ & 1.5 & \\
\hline & & 4.0 & $2.1 \mathrm{E}+01$ & 1.4 & \\
\hline & & 8.0 & $<0.04$ & & \\
\hline \multirow{9}{*}{$\begin{array}{l}\text { Campylobacter } \\
\text { jejuni (DSMZ } \\
4688)\end{array}$} & \multirow{6}{*}{$\mathrm{R} 1: 2.4 \mathrm{E}+06$} & & & $>1.1$ & \multirow{9}{*}{37} \\
\hline & & 0.3 & $1.1 \mathrm{E}+06$ & 1.4 & \\
\hline & & 0.8 & $1.5 \mathrm{E}+05$ & 1.4 & \\
\hline & & 1.1 & $1.1 \mathrm{E}+04$ & 2.1 & \\
\hline & & 2.0 & $2.4 \mathrm{E}+01$ & 2.5 & \\
\hline & & 0.3 & $4.6 \mathrm{E}+06$ & 0.0 & \\
\hline & \multirow[t]{3}{*}{$\mathrm{R} 2: 4.6 \mathrm{E}+06$} & 0.8 & $2.4 \mathrm{E}+04$ & 2.7 & \\
\hline & & $\begin{array}{l}1.1 \\
2.0\end{array}$ & $\begin{array}{c}1.5 \mathrm{E}+04 \\
9.3\end{array}$ & 2.2 & \\
\hline & & 2.0 & 9.3 & 2.8 & \\
\hline \multirow{7}{*}{$\begin{array}{l}\text { Campylobacter } \\
\text { jejuni } \\
\text { (environmental } \\
\text { strain MRA03 } \\
\text { 11) }\end{array}$} & \multirow{7}{*}{ R2: $1.5 \mathrm{E}+08$} & 1.0 & $9.3 \mathrm{E}+06$ & & \multirow{7}{*}{10} \\
\hline & & 2.0 & $1.1 \mathrm{E}+07$ & 1.2 & \\
\hline & & 3.0 & $1.1 \mathrm{E}+07$ & $\begin{array}{l}0.6 \\
0.4\end{array}$ & \\
\hline & & 10.0 & $4.0 \mathrm{E}+02$ & 0.4 & \\
\hline & & 2.0 & $4.6 \mathrm{E}+06$ & 0.6 & \\
\hline & & 3.0 & $1.1 \mathrm{E}+07$ & 0.8 & \\
\hline & & 8.0 & $9.0 \mathrm{E}+02$ & $\begin{array}{l}0.4 \\
0.7\end{array}$ & \\
\hline
\end{tabular}




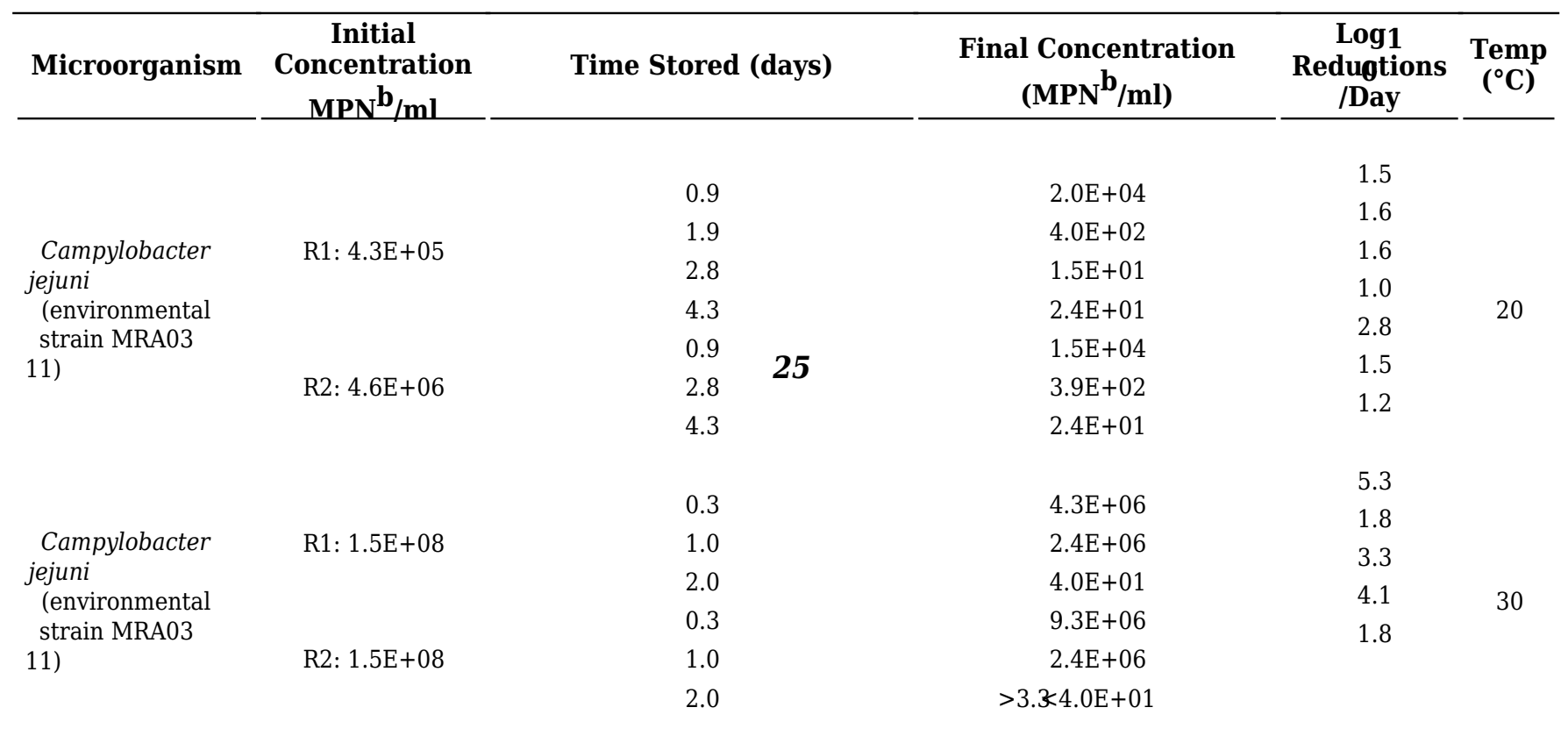

${ }^{a}$ Study done in Spain (Catalonia); ${ }^{b}$ MPN: Most probable number, ${ }^{c}$ R1: Replicate 1; ${ }^{d}$ R2: Replicate 2; ${ }^{\text {NRR }}$ Not reported.

Source: Rodriguez and Araujo, 2012.

The raw data kindly provided by Sarah Rodriguez, 5th July 2016. 


\section{Appendix B. Persistence of Campylobacter ${ }^{\text {a }}$ in environmental conditions in river water}

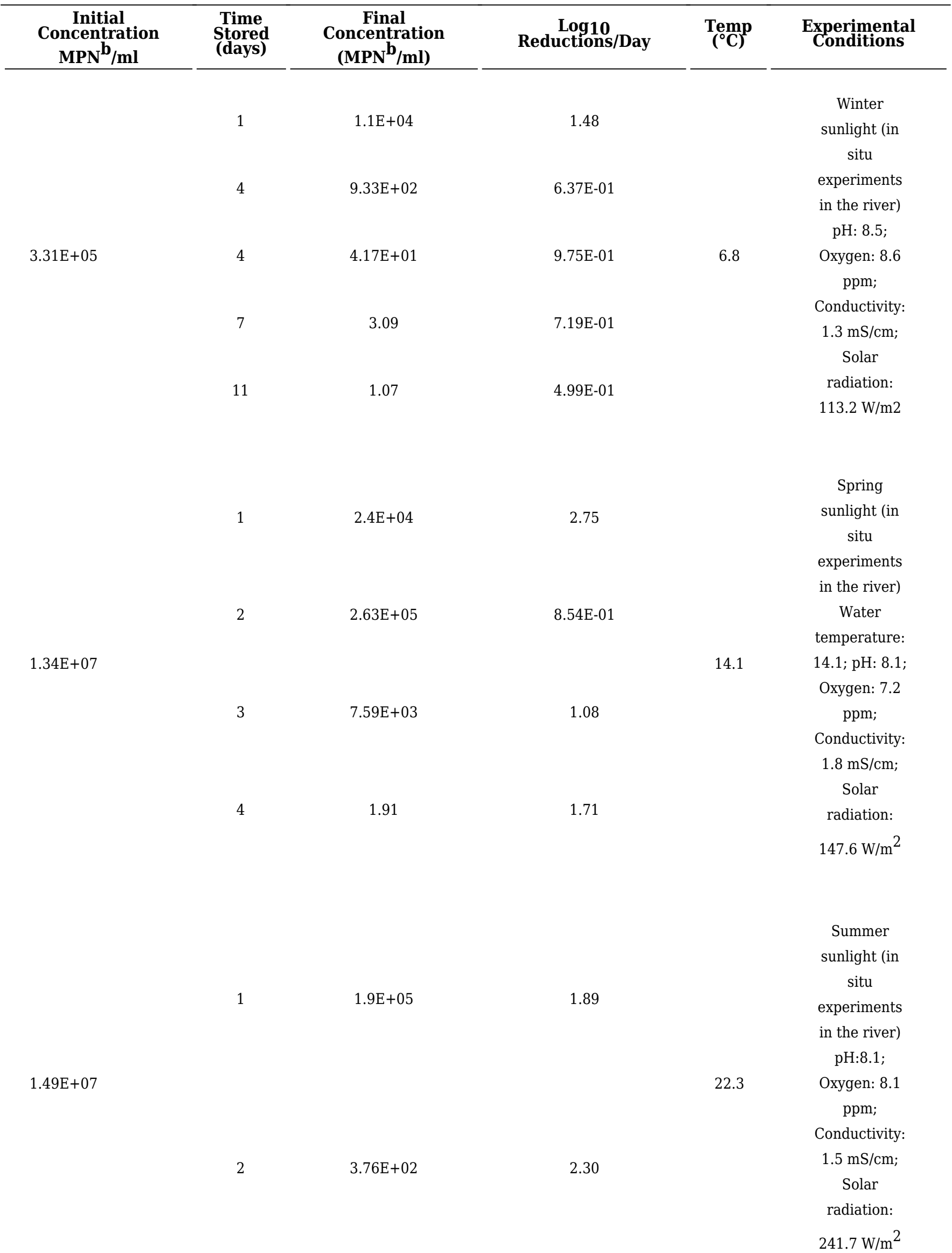




\begin{tabular}{|c|c|c|c|c|c|}
\hline $\begin{array}{c}\text { Initial } \\
\text { Concentration } \\
\mathrm{MPN}^{\mathbf{b}} / \mathbf{m l}\end{array}$ & $\begin{array}{l}\text { Time } \\
\text { Stored } \\
\text { (days) }\end{array}$ & $\begin{array}{c}\text { Final } \\
\text { Concentration } \\
\left(\mathrm{MPN}^{\mathbf{b}} / \mathrm{ml}\right)\end{array}$ & $\stackrel{\log 10}{\text { Reductions/Day }}$ & $\underset{\left({ }^{\circ} \mathbf{C}\right)}{\text { Temp }}$ & $\begin{array}{l}\text { Experiment } \\
\text { Conditions }\end{array}$ \\
\hline \multirow{6}{*}{$1.9 \mathrm{E}+03$} & 1 & $4.31 \mathrm{E}+02$ & $6.44 \mathrm{E}-01$ & \multirow{6}{*}{7.4} & $\begin{array}{l}\text { Winter shade } \\
\text { (in situ } \\
\text { experiments } \\
\text { in the river) }\end{array}$ \\
\hline & 2 & $5.15 E+02$ & 2.83E-01 & & pH: 8.2; \\
\hline & & & & & $\begin{array}{c}\text { Oxygen: } 7.2 \\
\text { ppm; }\end{array}$ \\
\hline & 3 & $6.14 \mathrm{E}+01$ & 4.97E-01 & & Conductivity: \\
\hline & & & & & $\begin{array}{c}1.8 \mathrm{mS} / \mathrm{cm} ; \\
\text { Solar }\end{array}$ \\
\hline & 4 & $7.76 \mathrm{E}+01$ & $3.47 \mathrm{E}-01$ & & $\begin{array}{l}\text { radiation: } \\
\text { shade }\end{array}$ \\
\hline \multirow{4}{*}{$2.4 \mathrm{E}+05$} & 1 & $9.3 \mathrm{E}+04$ & 4.12E-01 & \multirow{4}{*}{21.5} & $\begin{array}{c}\text { Summer } \\
\text { shade (in situ } \\
\text { experiments } \\
\text { in the river) }\end{array}$ \\
\hline & 2 & $9.3 \mathrm{E}+02$ & 1.21 & & $\begin{array}{c}\text { pH: } 7.9 ; \\
\text { Oxygen: } 3.5 \\
\text { ppm; }\end{array}$ \\
\hline & 3 & $2.41 \mathrm{E}+02$ & $9.99 \mathrm{E}-01$ & & $\begin{array}{l}\text { Conductivity: } \\
2.5 \mathrm{mS} / \mathrm{cm} \text {; }\end{array}$ \\
\hline & 4 & 4.97 & 1.17 & & $\begin{array}{l}\text { Solar } \\
\text { radiation: } \\
\text { shade }\end{array}$ \\
\hline
\end{tabular}

${ }^{\mathrm{a} C a m p y l o b a c t e r ~ j e j u n i ~(D S M Z ~ 4688) . ~}$

Source: Rodriguez and Araujo, 2012.

The raw data kindly provided by Sarah Rodriguez, $5^{\text {th }}$ July 2016. 


\section{References}

Abu-Halaweh, M., Bates, J. and Patel, B.K.C. (2005). Rapid detection and differentiation of pathogenic Campylobacter jejuni and Campylobacter coli by real-time PCR. Research in Microbiology. 156, pp. 107-114.

Abulreesh, H.H., Paget, T.A. and Goulder, R. (2006). Campylobacter in waterfowl and aquatic environments: Incidence and methods of detection. Environmental Science and Technology. 40, pp. 7122-7131.

Abulreesh, H.H., Paget, T.A. and Goulder, R. (2005). Recovery of thermophilic campylobacters from pond water and sediment and the problem of interference by background bacteria in enrichment culture. Water Research. 39, pp. 2877-2882.

Ahmed, A.U. and Sorensen, D.L. (1995). Kinetics of pathogen destruction during storage of dewatered biosolids. Water Environmental Research. 67, pp. 143-150.

Ahmed, W., Hodgers, L., Sidhu, J.P. and Toze, S. (2012). Fecal indicators and zoonotic pathogens in household drinking water taps fed from rainwater tanks in southeast Queensland, Australia. Applied and Environmental Microbiology. 78, pp. 219-226.

Ahmed, W., Hodgers, L., Sidhu, J.P.S. and Toze, S. (2012). Fecal Indicators and Zoonotic Pathogens in Household Drinking Water Taps Fed from Rainwater Tanks in Southeast Queensland, Australia. Applied and Environmental Microbiology. 78, pp. 219-226.

Alexandrino, M., Grohmann, E., Szewzyk, R. and Szewzyk, U. (2007). Application of culture-independent methods to assess the bacteria removal efficiency of subsurface flow constructed wetlands. Water Science and Technology. 56 (3), pp. 217-222.

Allos, B.M. (2001). Campylobacter jejuni infections: Update on emerging issues and trends. Clinical Infectious Diseases. 32, pp. 1201-1206.

Allos, B.M. (1997). Association between Campylobacter Infection and Guillain-Barré Syndrome. The Journal of Infectious Diseases. 176 (Supplement 2), pp. S125-S128.

Arimi, S.M., Fricker, C.R. and Park, R.W. (1988). Occurrence of 'thermophilic' campylobacters in sewage and their removal by treatment processes. Epidemiology and Infection. 101(2), pp. 279-286.

Arvanitidou, M., Stathopoulos, G.A., Constantinidis, T.C. and Katsouyannopoulos, V. (1995). The occurence of Salmonella, Campylobacter and Yersinia spp. in river and lake waters. Microbiological Research. 150, pp. 153-158.

Axelsson-Olsson, D., Waldenstrom, J., Broman, T., Olsen, B. and Holmberg, M. (2005). Protozoan Acanthamoeba polyphaga as a potential reservoir for Campylobacter jejuni. Applied and Environmental Microbiology. 71, pp. 987-992.

Baffone, W., Casaroli, A., Citterio, B., Pierfelici, L., Campana, R., Vittoria, E. et al. (2006). Campylobacter jejuni loss of culturability in aqueous microcosms and ability to resuscitate in a mouse model. International Journal of Food Microbiology. 107(1), pp. 83-91.

Bang, D.D., Wedderkopp, A., Pedersen, K. and Madsen, M. (2002). Rapid PCR using nested primers of the 16S rRNA and the hippuricase (hipO) genes to detect Campylobacter jejuni and Campylobacter coli in environmental samples. Molecular and Cellular Probes. 16, pp. 359-369.

Banihashemi, A., Van Dyke, M.I. and Huck, P.M. (2012). Long-amplicon propidium monoazide-PCR enumeration assay to detect viable Campylobacter and Salmonella. Journal of Applied Microbiology. 113, pp. 863-873.

Banting, G.S., Braithwaite, S., Scott, C., Kim, J., Jeon, B., Ashbolt, N. et al. (2016). Evaluation of various Campylobacterspecific qPCR assays for detection and enumeration of Campylobacteraceae in irrigation water and wastewater using a miniaturized MPN-qPCR assay. Applied and Environmental Microbiology. 82(15), pp. 4743-4756. 
Benoit, S.R., Lopez, B., Arvelo, W., Henao, O., Parsons, M.B., Reyes, L. et al. (2014). Burden of laboratory-confirmed Campylobacter infections in Guatemala 2008-2012: Results from a facility-based surveillance system. Journal of Epidemiology and Global Health. 4, pp. 51-59.

Berry, E.D., Wells, J.E., Archibeque, S.L., Ferrell, C.L., Freetly, H.C. and Miller, D.N. (2006). Influence of genotype and diet on steer performance, manure odor, and carriage of pathogenic and other fecal bacteria. II. Pathogenic and other fecal bacteria. Journal of Animal Science. 84(9), pp. 2523-2532.

Betaieb, M. and Jones, B.K. (1990). Thermophilic Campylobacters in two sewage treatment plants in Libya. Letters in Applied Microbiology. 11, pp. 93-95.

Bischel, H.N., Duygan, B.D., Strande, L., McArdell, C.S., Udert, K.M. and Kohn, T. (2015). Pathogens and pharmaceuticals in source-separated urine in eThekwini, South Africa. Water Research. 85, pp. 57-65.

Black, R.E., Perlman, D., Clements, M.L., Levine, M.M. and Blaser, M.J. (1992). Human volunteer studies with Campylobacter jejuni. Campylobacter jejuni. Current status and future trends. (Nachamkin, I., Blaser, M.J. and Tompkins, L.S., ed.). Americal Society for Microbiology. Washington, DC.

Black, R.E., Levine, M.M., Clements, M.L., Hughes, T.P. and Blaser, M.J. (1988). Experimental Campylobacter jejuni infection in humans. The Journal of Infectious Diseases. 157, pp. 472-479.

Blaser, M.J. and Wang, W.L. (1980). Campylobacter infections in human beings. Journal of Pediatrics. 96(2), pp. 343.

Blaser, M.J. (1997). Epidemiologic and Clinical Features of Campylobacter jejuni Infections. The Journal of Infectious Diseases. 176 (Supplement 2), pp. S103-S105.

Blaser, M.J., Smith, P.F., Wang, W.L. and Hoff, J.C. (1986). Inactivation of Campylobacter jejuni by chlorine and monochloramine. Applied and Environmental Microbiology. 51 (2), pp. 307-311.

Bolton, F.J., Coates, D., Hutchinson, D.N. and Godfree, A.F. (1987). A study of thermophilic campylobacters in a river system. Journal of Applied Bacteriology. 62, pp. 167-176.

Bonetta, S.I., Pignata, C., Lorenzi, E., De Ceglia, M., Meucci, L., Bonetta, S.A. et al. (2016). Detection of pathogenic Campylobacter, E. coli O157:H7 and Salmonella spp. in wastewater by PCR assay. Environmental Science and Pollution Research. 23(15), pp. 15302-15309.

Bopp, D.J., Sauders, B.D., Waring, A.L., Ackelsberg, J., Dumas, N., Braun-Howland, E. et al. (2003). Detection, isolation, and molecular subtyping of Escherichia coli 0157 : H7 and Campylobacter jejuni associated with a large waterborne outbreak. Journal of Clinical Microbiology. 41, pp. 174-180.

Boyle, M., Sichel, C., Fernández-Ibñez, P., Arias-Quiroz, G.B., Iriarte-Puña, M., Mercado, A. et al. (2008). Bactericidal effect of solar water disinfection under real sunlight conditions. Applied and Environmental Microbiology. 74, pp. $2997-3001$.

Brennhovd, O., Kapperud, G. and Langeland, G. (1992). Survey of thermotolerant Campylobacter spp and Yersinia spp in 3 surface-water sources in Norway. International Journal of Food Microbiology. 15, pp. 327-338.

Bronowski, C., James, C.E. and Winstanley, C. (2014). Role of environmental survival in transmission of Campylobacter jejuni. FEMS Microbiology Letters. 356, pp. 8-19.

Brooks, J.T., Ochieng, J.B., Kumar, L., Okoth, G., Shapiro, R.L., Wells, J.G. et al. (2006). Surveillance for bacterial diarrhea and antimicrobial resistance in rural western Kenya, 1997-2003. Clinical Infectious Diseases. 43, pp. 393-401.

Brown, P.E., Christensen, O.F., Clough, H.E., Diggle, P.J., Hart, C.A., Hazel, S. et al. (2004). Frequency and spatial distribution of environmental Campylobacter spp. Applied and Environmental Microbiology. 70, pp. 6501-6511.

Bui, X.T., Wolff, A., Madsen, M. and Bang, D.D. (2011). Fate and survival of Campylobacter coli in swine manure at various temperature. Frontiers in Microbiology. 2(262), . 
Burgess, C.M., Gianotti, A., Gruzdev, N., Holah, J., Knøchel, S., Lehner, A. et al. (2016). The response of foodborne pathogens to osmotic and desiccation stresses in the food chain. International Journal of Food Microbiology. 221, pp. 37-53.

Butler, R.C., Lund, V. and Carlson, D.A. (1987). Susceptibility of Campylobacter jejuni and Yersinia enterocolitica to UV radiation. Applied and Environmental Microbiology. 53 (2), pp. 375-378.

Butzler, J.P. (2004). Campylobacter, from obscurity to celebrity. Clinical Microbiology and Infection. 10, pp. 868-876.

CDC (Submitted). Foodborne Diseases Active Surveillance Network (FoodNet): FoodNet Surveillance Report for 2014 (Final Report).

Cenciarini-Borde, C., Courtois, S. and La Scola, B. (2009). Nucleic acids as viability markers for bacteria detection using molecular tools. Future Microbiology. 4, pp. 45-64.

Clark, S.T., Gilbride, K.A., Mehrvar, M., Laursen, A.E., Bostan, V., Pushchak, R. et al. (2011). Evaluation of low-copy genetic targets for waterborne bacterial pathogen detection via qPCR. Water Research. 45, pp. 3378-3388.

Close, M., Dann, R.F., Ball, A.F., Pirie, R.F., Savill, M.F. and Smith, Z. (2008). Microbial groundwater quality and its health implications for a border-strip irrigated dairy farm catchment, South Island, New Zealand. Journal of Water and Health JID - 101185420. 6 (1), pp. 83-98.

Cody, A.J., McCarthy, N.D., Bray, J.E., Wimalarathna, H.M., Colles, F.M., Jansen van Rensburg, M.J. et al. (2015). Wild birdassociated Campylobacter jejuni isolates are a consistent source of human disease, in Oxfordshire, United Kingdom. Environmental Microbiology Reports. 7(5), pp. 782-788.

Cools, I., Uyttendaele, M., Caro, C., D'Haese, E., Nelis, H.J. and Debevere, J. (2003). Survival of Campylobacter jejuni strains of different origin in drinking water. Journal of Microbiological Methods. 94 (5), pp. 886-892.

Daczkowska Kozon, E. and Brzostek-Nowakowska, J. (2001). Campylobacter spp. in waters of three main Western Pomerania water bodies. International Journal of Hygiene and Environmental Health. 203, pp. 435-443.

Debruyne, L., Gevers, D. and Vandamme, P. (2008). Taxonomy of the Family Campylobacteraceae. Campylobacter. 3rd, (Nachamkin, I., Szymanski, C.M. and Blaser, M.J., ed.). Americal Society for Microbiology. Washington, DC. pp. 3-25.

Debruyne, L., On, S., De Brandt, E. and Vandamme, P. (2009). Novel Campylobacter lari-like bacteria from humans and molluscs: description of Campylobacter peloridis sp. nov., Campylobacter lari subsp. concheus subsp. nov. and Campylobacter lari subsp. larisubsp. nov. International Journal of Systematic and Evolutionary Microbiology. 59(5), pp. 1126-1132.

de Haan, C.P.A., Kivistö, R.I., Hakkinen, M., Corander, J. and Hänninen, M.L. (2010). Multilocus sequence types of Finnish bovine Campylobacter jejuni isolates and their attribution to human infections. BMC Microbiology. 10, pp. 200.

Dekeyser, P., Gossuin-Detrain, M., Butzler, J.P. and Sternon, J. (1972). Acute Enteritis Due to Related Vibrio: First Positive Stool Cultures. The Journal of Infectious Diseases. 125, pp. 390-392.

Denis, M.,.Tanguy, M., Chidaine, B., Laisney, M.J., Mégraud, F. and Fravalo, P. (2011). Description and sources of contamination by Campylobacter spp. of river water destined for human consumption in Brittany, France. Pathologie Biologie. 59, pp. 256-263.

Deogratias, A.P., Mushi, M.F., Paterno, L., Tappe, D., Seni, J., Kabymera, R. et al. (2014). Prevalence and determinants of Campylobacter infection among under five children with acute watery diarrhea in Mwanza, North Tanzania. Archives of Public Health. 72, pp. 17.

Diergaardt, S.M., Venter, S.N., Spreeth, A., Theron, J. and Brozel, V.S. (2004). The occurrence of campylobacters in water sources in South Africa. Water Research. 38, pp. 2589-2595.

Duggan, J., Bates, M.P. and Phillips, C.A. (2001). The efficacy of subsurface flow reed bed treatment in the removal of 
Campylobacter spp., faecal coliforms and Escherichia coli from poultry litter. International Journal of Environmental Health Research. 11, pp. 168-180.

EFSA (2011). Scientific opinion on an update on the present knowledge on the occurrence and control of foodborne viruses. European Food Safety Authority Journal. 9, pp. 2190 [96 pp.].

Ellouze, M., Saddoud, A., Dhouib, A. and Sayadi, S. (2009). Assessment of the impact of excessive chemical additions to municipal wastewaters and comparison of three technologies in the removal performance of pathogens and toxicity. Microbiological Research. 164(2), pp. 138-148.

Ellström, P., Hansson, I., Söderström, C., Engvall, E.O. and Rautelin, H. (2014). A prospective follow-up study on transmission of Campylobacter from poultry to abattoir workers. Foodborne Pathogens and Disease. 11, pp. 684-688.

Engvall, E.O., Brandstrom, B., Gunnarsson, A., Morner, T., Wahlstrom, H. and Fermer, C. (2002). Validation of a polymerase chain reaction/restriction enzyme analysis method for species identification of thermophilic campylobacters isolated from domestic and wild animals. Journal of Applied Microbiology. 92, pp. 47-54.

European Food Safety Authority, European Centre for Disease Prevention Control (2015). The European Union summary report on trends and sources of zoonoses, zoonotic agents and food-borne outbreaks in 2013. EFSA Journal. 13, pp. 3999.

Feodoroff, B., Ellström, P., Hyytiäinen, H., Sarna, S., Hänninen, M.L. and Rautelin, H. (2010). Campylobacter jejuni isolates in Finnish patients differ according to the origin of infection. Gut Pathogens. 2(1), pp. 22.

Ferguson, C.M., Croke, B.F.W., Norton, J.P., Haydon, S., Davies, C.M., Krogh, M.H. et al. (2010). Modeling of variations in watershed pathogen concentrations for risk management and load estimations. Project \# 3124. pp. 288.

Fernández, H., Vergara, M. and Tapia, F. (1985). Dessication resistance in thermotolerant Campylobacter species. Infection. 13, pp. 197.

Fernández, H. (2011). Campylobacter and campylobacteriosis: a view from South America. Revista Peruana de Medicina Experimental y Salud Pública. 28, pp. 121-127.

Fittipaldi, M., Nocker, A. and Codony, F. (2012). Progress in understanding preferential detection of live cells using viability dyes in combination with DNA amplification. Journal of Microbiological Methods. 91, pp. 276-289.

Frost, J.A. (2001). Current epidemiological issues in human campylobacteriosis. Journal of Applied Microbiology. 90, pp. 85S-95S.

Gibney, K.B., O’Toole, J., Sinclair, M. and Leder, K. (2014). Disease burden of selected gastrointestinal pathogens in Australia, 2010. The Journal of Infectious Diseases. 28, pp. 176-185.

Gilpin, B.J., Scholes, P., Robson, B. and Savill, M.G. (2008). The transmission of thermotolerant Campylobacter spp. to people living or working on dairy farms in New Zealand. Zoonoses Public Health. 55 (7), pp. 352-360.

Gin, K.Y. and Goh, S.G. (2013). Modeling the effect of light and salinity on viable but non-culturable (VBNC) Enterococcus. Water Research. 47(10), pp. 3315-3328.

Gonzalez, M. and Hänninen, M.L. (2012). Effect of temperature and antimicrobial resistance on survival of Campylobacter jejuni in well water: application of the Weibull model. Journal of Applied Microbiology. 113, pp. 284-293.

Gras, L.M., Smid, J.H., Wagenaar, J.A., de Boer, A.G., Havelaar, A.H., Friesema, I.H.M. et al. (2012). Risk Factors for Campylobacteriosis of Chicken, Ruminant, and Environmental Origin: A Combined Case-Control and Source Attribution Analysis. PLoS One. 7, pp. e42599.

Griekspoor, P., Colles, F.M., McCarthy, N.D., Hansbro, P.M., Ashhurst-Smith, C., Olsen, B. et al. (2013). Marked host specificity and lack of phylogeographic population structure of Campylobacter jejuni in wild birds. Molecular Ecology. 22(5), pp. 1463-1472. 
Gu, G., Luo, Z., Cevallos-Cevallos, J.M., Adams, P., Vellidis, G., Wright, A. et al. (2013). Occurrence and population density of Campylobacter jejuni in irrigation ponds on produce farms in the Suwannee River Watershed. Canadian Journal of Microbiology. 59 (5), pp. 339-346.

Gunnarsdóttir, M.J., Gardarsson, S.M., Elliott, M., Sigmundsdottir, G. and Bartram, J. (2012). Benefits of Water Safety Plans: microbiology, compliance, and public health. Environmental Science and Technology. 46 (14), pp. 7782-7789.

Guzman-Herrador, B., Carlander, A., Ethelberg, S., B. de Blasio, F., Kuusi, M., Lund, V. et al. (2015). Waterborne outbreaks in the Nordic countries, 1998 to 2012. Eurosurveillance. 20(24), pp. 21160.

Höglund, C., Stenström, T.A. and Ashbolt, N. (2002). Microbial risk assessment of source-separated urine used in agriculture. Waste Management and Research. 20, pp. 150-161.

Höller, C. (1988). [Quantitative and qualitative studies of Campylobacter in a sewage treatment plant] German. Zentralblatt für Bakteriologie, Mikrobiologie und Hygiene. 1 Abt. Originale B. 185(4-5), pp. 326-339.

Hörman, A., Rimhanen-Finne, R., Maunula, L., von Bonsdorff, C.H., Torvela, N., Heikinheimo, A. et al. (2004). Campylobacter spp., Giardia spp., Cryptosporidium spp., Noroviruses, and Indicator Organisms in Surface Water in Southwestern Finland, 2000-2001. Applied and Environmental Microbiology. 70, pp. 87-95. doi: 10.1128/AEM.70.1.87-95.2004.

Habib, I., Uyttendaele, M. and De Zutter, L. (2010). Survival of poultry-derived Campylobacter jejuni of multilocus sequence type clonal complexes 21 and 45 under freeze, chill, oxidative, acid and heat stresses. Food Microbiology. 27, pp. 829-834.

Hai, F.I., Riley, T., Shawkat, S., Magram, S.F. and Yamamoto, K. (2014). Removal of pathogens by membrane bioreactors: A Review of the mechanisms, influencing factors and reduction in chemical disinfectant dosing. Water. 6, pp. 3603-3630.

Hakkinen, M., Heiska, H. and Hanninen, M.L. (2007). Prevalence of Campylobacter spp. in cattle in Finland and antimicrobial susceptibilities of bovine Campylobacter jejuni strains. Applied and Environmental Microbiology. 73, pp. 3232-3238.

Hanninen, M.L., Haajanen, H., Pummi, T., Wermundsen, K., Katila, M.L., Sarkkinen, H. et al. (2003). Detection and typing of Campylobacter jejuni and Campylobacter coli and analysis of indicator organisms in three waterborne outbreaks in Finland. Applied and Environmental Microbiology. 69, pp. 1391-1396.

Hannu, T., Mattila, L., Rautelin, H., Pelkonen, P., Lahdenne, P., Siitonen, A. et al. (2002). Campylobacter-triggered reactive arthritis: a population-based study. Rheumatology (Oxford). 41(3), pp. 312-318.

Hellein, K.N., Battie, C., Tauchman, E., Lund, D., Oyarzabal, O.A. and Lepo, J.E. (2011). Culture-based indicators of fecal contamination and molecular microbial indicators rarely correlate with Campylobacter spp. in recreational waters. Journal of Water and Health. 9, pp. 695-707.

Hijnen, W.A.M., Beerendonk, E.F. and Medema, G.J. (2006). Inactivation credit of UV radiation for viruses, bacteria and protozoan (oo)cysts in water: A review. Water Research. 40, pp. 3-22.

Hijnen, W.A.M., Schijven, J.F., Bonne, P., Visser, A. and Medema, G.J. (2004). Elimination of viruses, bacteria and protozoan oocysts by slow sand filtration. Water Science and Technology. 50, pp. 147-154.

Hijnen, W.A.M., Van Veenendaal, D.A., Van der Speld, W.M.H., Visser, A., Hoogenboezem, W. and Van der Kooij, D. (2000). Enumeration of faecal indicator bacteria in large water volumes using on site membrane filtration to assess water treatment efficiency. Water Research. 34, pp. 1659-1665.

Hokajärvi, A.M., Pitkänen, T., Siljanen, H.M., Nakari, U.M., Torvinen, E., Siitonen, A. et al. (2013). Occurrence of thermotolerant Campylobacter spp. and adenoviruses in Finnish bathing waters and purified sewage effluents. Journal of Water and Health. 11, pp. 120-134.

Horan, N.J., Fletcher, L., Betmal, S.M., Wilks, S.A. and Keevil, C.W. (2004). Die-off of enteric bacterial pathogens during 
mesophilic anaerobic digestion. Water Research. 38, pp. 1113-1120.

$\mathrm{Hu}$, T.L. and Kuo, P.C. (2011). Isolation of Campylobacter sp in surface waters of Taiwan. Journal of Microbiology, Immunology and Infection. 44, pp. 15-20.

Hutchison, M.L., Walters, L.D., Avery, S.M. and Moore, A. (2005). Decline of zoonotic agents in livestock waste and bedding heaps. Journal of Applied Microbiology. 99, pp. 354-362.

Inglis, G.D., Kalischuk, L.D. and Busz, H.W. (2004). Chronic shedding of Campylobacter species in beef cattle. Journal of Applied Microbiology. 97, pp. 410-420.

Jackson, D.N., Davis, B., Tirado, S.M., Duggal, M., van Frankenhuyzen, J.K., Deaville, D. et al. (2009). Survival mechanisms and culturability of Campylobacter jejuni under stress conditions. Antonie Van Leeuwenhoek. 96(4), pp. $377-394$.

Jacobs-Reitsma, W., Lyhs, U. and Wagenaar, J. (2008). Campylobacter in food supply. Campylobacter. 3rd, (Nachamkin, I., Szymanski, C.M. and Blaser, M.J., ed.). Americal Society for MIcrobiology. Washington, DC. pp. 627-644.

Jakopanec, I., Borgen, K., Vold, L., Lund, H., Forseth, T., Hannula, R. et al. (2008). A large waterborne outbreak of campylobacteriosis in Norway: The need to focus on distribution system safety. Bmc Infectious Diseases. 8,

Jensen, A.N., Andersen, M.T., Dalsgaard, A., Baggesen, D.L. and Nielsen, E.M. (2005). Development of real-time PCR and hybridization methods for detection and identification of thermophilic Campylobacter spp. in pig faecal samples. Journal of Applied Microbiology. 99, pp. 292-300.

Jokinen, C.C., Edge, T.A., Koning, W., Laing, C.R., Lapen, D.R., Miller, J. et al. (2012). Spatial and Temporal Drivers of Zoonotic Pathogen Contamination of an Agricultural Watershed. Journal of Environmental Quality. 41, doi: $10.2134 /$ jeq2011.0203.

Jokinen, C.C., Schreier, H., Mauro, W., Taboada, E., Isaac-Renton, J.L., Topp, E. et al. (2010). The occurrence and sources of Campylobacter spp., Salmonella enterica and Escherichia coli O157:H7 in the Salmon River, British Columbia, Canada. Journal of Water and Health. 8(2), pp. 374-386.

Jones, K., Betaieb, M. and Telford, D.R. (1990). Seasonal variation of thermophilic campylobacters in sewage sludge. The Journal of Applied Bacteriology. 69 (2), pp. 292-300.

Jones, K. (2001). Campylobacters in water, sewage and the environment. Journal of Applied Microbiology. 90, pp. 68S-79S.

Josefsen, M.H., Jacobsen, N.R. and Hoorfar, J. (2004). Enrichment followed by quantitative PCR both for rapid detection and as a tool for quantitative risk assessment of food-borne thermotolerant campylobacters. Applied and Environmental Microbiology. 70, pp. 3588-3592.

Kärenlampi, R. and Hänninen, M.L. (2004). Survival of Campylobacter jejuni on various fresh produce. International Journal of Food Microbiology. 97, pp. 187-195.

Kärenlampi, R.I., Tolvanen, T.P. and Hänninen, M.L. (2004). Phylogenetic Analysis and PCR-Restriction Fragment Length Polymorphism Identification of Campylobacter Species Based on Partial groEL Gene Sequences. Journal of Clinical Microbiology. 42, pp. 5731-5738.

Kärenlampi, R., Rautelin, H., Schönberg-Norio, D., Paulin, L. and Hänninen, M.L. (2007). Longitudinal Study of Finnish Campylobacter jejuni and $C$. coli Isolates from Humans, Using Multilocus Sequence Typing, Including Comparison with Epidemiological Data and Isolates from Poultry and Cattle. Applied and Environmental Microbiology. 73, pp. 148-155.

Kapperud, G., Espeland, G., Wahl, E., Walde, A., Herikstad, H., Gustavsen, S. et al. (2003). Factors associated with increased and decreased risk of Campylobacter infection: A prospective case-control study in Norway. American Journal of Epidemiology. 158, pp. 234-242.

Kauppinen, A., Martikainen, K., Matikka, V., Veijalainen, A.M., Pitkänen, T., Heinonen-Tanski, H. et al. (2014). Sand filters for removal of microbes and nutrients from wastewater during a one-year pilot study in a cold temperate climate. Journal 
of Environmental Management. 133, pp. 206-213.

Kearney, T.E., Larkin, M.J. and Levett, P.N. (1993). The effect of slurry storage and anaerobic digestion on survival of pathogenic bacteria. The Journal of Applied Bacteriology. 74, pp. 86-93.

Kelly, D.J. (2001). The physiology and metabolism of Campylobacter jejuni and Helicobacter pylori. Journal of Applied Microbiology. 90, pp. 16S-24S.

Kendall, M.E., Crim, S., Fullerton, K., Han, P.V., Cronquist, A.B., Shiferaw, B. et al. (2012). Travel-Associated Enteric Infections Diagnosed After Return to the United States, Foodborne Diseases Active Surveillance Network (FoodNet), 2004-2009. Clinical Infectious Diseases. 54 (Suppl 5), pp. S480-S487.

Khalil, K., Lindblom, G.B., Mazhar, K. and Kaijser, B. (1994). Flies and water as reservoirs for bacterial enteropathogens in urban and rural areas in and around Lahore, Pakistan. Epidemiology and Infection. 113 (3), pp. 435-444.

Khan, I.U.H. and Edge, T.A. (2007). Development of a novel triplex PCR assay for the detection and differentiation of thermophilic species of Campylobacter using 16S-23S rDNA internal transcribed spacer (ITS) region. Journal of Applied Microbiology. 103(6), pp. 2561-2569.

Khan, I.U.H., Gannon, V., Jokinen, C.C., Kent, R., Koning, W., Lapen, D.R. et al. (2014). A national investigation of the prevalence and diversity of thermophilic Campylobacter species in agricultural watersheds in Canada. Water Research. 61, pp. 243-252.

Kim, J., Oh, E., Banting, G.S., Braithwaite, S., Chui, L., Ashbolt, N.J. et al. (2016). A novel culture method for enhanced selective isolation of Campylobacter jejuni from wastewater. Frontiers in Microbiology. Manuscript ID: 213389,.

Kirkpatrick, B.D. and Tribble, D.R. (2011). Update on human Campylobacter jejuni infections. Current Opinion in Gastroenterology. 27 (1), pp. 1-7.

Klein, M., Brown, L., Ashbolt, N.J., Stuetz, R.M. and Roser, D.J. (2011). Inactivation of indicators and pathogens in cattle feedlot manures and compost as determined by molecular and culture assays. FEMS Microbiology Ecology. 77 (1), pp. 200-210.

Koenraad, P., Giesendorf, B.A.J., Henkens, M.H.C., Beumer, R.R. and Quint, W.G.V. (1995). Methods for the detection of Campylobacter in sewage - Evaluation of efficacy of enrichment and isolation media, applicability of polymerase chainreaction and latex agglutination assay. Journal of Microbiological Methods. 23, pp. 309-320.

Koenraad, P., Hazeleger, W.C., Vanderlaan, T., Beumer, R.R. and Rombouts, F.M. (1994). Survey of Campylobacter spp in sewage plants in the Netherlands. Food Microbiology. 11, pp. 65-73.

Koenraad, P., Rombouts, F.M. and Notermans, S.H.W. (1997). Epidemiological aspects of thermophilic Campylobacter in water-related environments: A review. Water Environment Research. 69, pp. 52-63.

Koivunen, J. and Heinonen-Tanski, H. (2005). Inactivation of enteric microorganisms with chemical disinfectants, UV irradiation and combined chemical/UV treatments. Water Research. 39, pp. 1519-1526.

Korczak, B.M., Stieber, R., Emler, S., Burnens, A.P., Frey, J. and Kuhnert, P. (2006). Genetic relatedness within the genus Campylobacter inferred from $r p o B$ sequences. International Journal of Systematic and Evolutionary Microbiology. 56, pp. 937-945.

Korhonen, L.K. and Martikainen, P.J. (1991). Comparison of the survival of Campylobacter jejuni and Campylobacter coli in culturable form in surface water. Canadian Journal of Microbiology. 37, pp. 530-533.

Kotloff, K.L., Nataro, J.P., Blackwelder, W.C., Nasrin, D., Farag, T.H., Panchalingam, S. et al. (2013). Burden and aetiology of diarrhoeal disease in infants and young children in developing countries (the Global Enteric Multicenter Study, GEMS): a prospective, case-control study. Lancet. 382, pp. 209-22.

Kovanen, S., Kivistö, R., Llarena, A.K., Zhang, J., Kärkkäinen, U.M., Tuuminen, T. et al. (2016). Tracing isolates from 
domestic human Campylobacter jejuni infections to chicken slaughter batches and swimming water using whole-genome multilocus sequence typing. International Journal of Food Microbiology. 226, pp. 53-60.

Kovanen, S.M., Kivistö, R.I., Rossi, M., Schott, T., Kärkkäinen, U.M., Tuuminen, T. et al. (2014). Multilocus Sequence Typing (MLST) and Whole-Genome MLST of Campylobacter jejuni Isolates from Human Infections in Three Districts during a Seasonal Peak in Finland. Journal of Clinical Microbiology. 52, pp. 4147-4154.

Kubota, K., Kasuga, F., Iwasaki, E., Inagaki, S., Sakurai, Y., Komatsu, M. et al. (2011). Estimating the Burden of Acute Gastroenteritis and Foodborne Illness Caused by Campylobacter, Salmonella, and Vibrio parahaemolyticus by Using Population-Based Telephone Survey Data, Miyagi Prefecture, Japan, 2005 to 2006. Journal of Food Protection. 74, pp. 1592-1598.

Kuusi, M., Nuorti, J.P., Hanninen, M.L., Koskela, M., Jussila, V., Kela, E. et al. (2005). A large outbreak of campylobacteriosis associated with a municipal water supply in Finland. Epidemiology and Infection. 133, pp. 593-601.

Kwan, P.S.L., Barrigas, M., Bolton, F.J., French, N.P., Gowland, P., Kemp, R. et al. (2008). Molecular Epidemiology of Campylobacter jejuni Populations in Dairy Cattle, Wildlife, and the Environment in a Farmland Area. Applied and Environmental Microbiology. 74, pp. 5130-5138.

Kwan, P.S.L., Xavier, C., Santovenia, M., Pruckler, J., Stroika, S., Joyce, K. et al. (2014). Multilocus Sequence Typing Confirms Wild Birds as the Source of a Campylobacter Outbreak Associated with the Consumption of Raw Peas. Applied and Environmental Microbiology. 80, pp. 4540-4546.

Lane, R. and Briggs, S. (2014). Campylobacteriosis in New Zealand: room for further improvement. The New Zealand Medical Journal. 27, pp. 2-9.

Lastovica, A.J. and Allos, B.M. (2008). Clinical Significance of Campylobacter and related species other than Campylobacter jejuni and Campylobacter coli. Campylobacter. 3rd, (Nachamkin, I., Szymanski, C.M. and Blaser, M.J., ed.). Americal Society for Microbiology. Washington, DC.

Lauria-Filgueiras, A.L. and Hofer, E. (1998). Diversity of Campylobacter Isolates from Three Activated Sludge Systems. Memórias do Instituto Oswaldo Cruz. 93(3), pp. 295-298.

Lehtola, M.J., Pitkänen, T., Miebach, L. and Miettinen, I.T. (2006). Survival of Campylobacter jejuni in potable water biofilms: a comparative study with different detection methods. Water Science and Technology. 54, pp. 57-61.

Lengerh, A., Moges, F., Unakal, C. and Anagaw, B. (2013). Prevalence, associated risk factors and antimicrobial susceptibility pattern of Campylobacter species among under five diarrheic children at Gondar University Hospital, Northwest Ethiopia. BMC Pediatrics. 13, pp. 82-82.

Levantesi, C., La Mantia, R., Masciopinto, C., Bockelmann, U., Ayuso-Gabella, M.N., Salgot, M. et al. (2010). Quantification of pathogenic microorganisms and microbial indicators in three wastewater reclamation and managed aquifer recharge facilities in Europe. The Science of the Total Environment. 408, pp. 4923-4930.

Levesque, S., Fournier, E., Carrier, N., Frost, E., Arbeit, R.D. and Michaud, S. (2013). Campylobacteriosis in Urban versus Rural Areas: A Case-Case Study Integrated with Molecular Typing to Validate Risk Factors and to Attribute Sources of Infection. PLOS ONE. 8, pp. e83731.

Linton, D., Owen, R.J. and Stanley, J. (1996). Rapid identification by PCR of the genus Campylobacter and of five Campylobacter species enteropathogenic for man and animals. Research in Microbiology. 147, pp. 707-718.

Llarena, A.K., Skar de Haan, C.P.A., Rossi, M. and Hänninen, M.L. (2015). Characterization of the Campylobacter jejuni Population in the Barnacle Geese Reservoir. Zoonoses and Public Health. 62, pp. 209-221.

Lu, J., Ryu, H., Domingo, J.W.Santo, Griffith, J.F. and Ashbolt, N. (2011). Molecular detection of Campylobacter spp. in California gull (Larus californicus) excreta. Applied and Environmental Microbiology. 77, pp. 5034-5039.

Lu, J., Ryu, H., Vogel, J., Santo Domingo, J. and Ashbolt, N.J. (2013). Molecular detection of Campylobacter spp. and fecal 
indicator bacteria during the northern migration of sandhill cranes (Grus canadensis) at the central Platte river. Applied and Environmental Microbiology. 79, pp. 3762-3769.

Mandrell, R.E., Harden, L.A., Bates, A., Miller, W.G., Haddon, W.F. and Fagerquist, C.K. (2005). Speciation of Campylobacter coli, C. jejuni, C. helveticus, C. lari, C. sputorum, and C. upsaliensis by Matrix-Assisted Laser Desorption Ionization-Time of Flight Mass Spectrometry. Applied and Environmental Microbiology. 71, pp. 6292-6307.

Mangen, M.J.J., Bouwknegt, M., Friesema, I.H.M., Haagsma, J.A., Kortbeek, L.M., Tariq, L. et al. (2015). Cost-of-illness and disease burden of food-related pathogens in the Netherlands, 2011. International Journal of Food Microbiology. 196, pp. 84-93.

Marshall, J.K., Thabane, M., Garg, A.X., Clark, W.F., Salvadori, M. and Collins, S.M. (2006). Incidence and Epidemiology of Irritable Bowel Syndrome After a Large Waterborne Outbreak of Bacterial Dysentery. Gastroenterology. 131, pp. 445-450.

Mason, J., Iturriza-Gomara, M., O'Brien, S.J., Ngwira, B.M., Dove, W., Maiden, M.C.J. et al. (2013). Campylobacter Infection in Children in Malawi Is Common and Is Frequently Associated with Enteric Virus Co-Infections. PLOS ONE. 8, pp. e59663.

McLaughlin, M.R., Brooks, J.P. and Adeli, A. (2012). Temporal flux and spatial dynamics of nutrients, fecal indicators, and zoonotic pathogens in anaerobic swine manure lagoon water. Water Research. 46, pp. 4949-4960.

Medema, G.J., Teunis, P.F.M., Havelaar, A.H. and Haas, C.N. (1996). Assessment of the dose-response relationship of Campylobacter jejuni. International Journal of Food Microbiology. 30, pp. 101-111.

Michaud, S., Menard, S. and Arbeit, R.D. (2004). Campylobacteriosis, Eastern Townships, QuÃ@ bec. Emerging Infectious Diseases. 10, pp. 1844-1847.

Miller, W.G. and Mandrell, R.E. (2005). Prevalence of Campylobacter in the Food and Water Supply: Incidence, Outbreaks, Isolation and Detection. 103, (Konkel, M.E., ed.). Horizon Bioscience. Norfolk, UK.

Miller, W.G., Parker, C.T., Heath, S. and Lastovica, A.J. (2007). Identification of genomic differences between Campylobacter jejuni subsp. jejuni and C. jejuni subsp. doylei at the nap locus leads to the development of a C. jejuni subspeciation multiplex PCR method. BMC Microbiology. 7, pp. 11.

MMWR Recommendation Report (2014). Incidence and Trends of Infection with Pathogens Transmitted Commonly Through Food - Foodborne Diseases Active Surveillance Network, 10 U.S. Sites, 2006-2013. MMWR. Morbidity and Mortality Weekly Report. 63(15), pp. 328-332.

Moffatt, C.R., Greig, A., Valcanis, M., Gao, W., Seemann, T., Howden, B.P. et al. (2016). A large outbreak of Campylobacter jejuni infection in a university college caused by chicken liver patee, Australia, 2013. Epidemiology and Infection. 144, pp. 2971-2978.

Moore, J., Caldwell, P. and Millar, B. (2001). Molecular detection of Campylobacter spp. in drinking, recreational and environmental water supplies. International Journal of Hygiene and Environmental Health. 204, pp. 185-189.

Moreno, Y., Botella, S., Alonso, J.L., Ferrus, M.A., Hernandez, M. and Hernandez, J. (2003). Specific Detection of Arcobacter and Campylobacter Strains in Water and Sewage by PCR and Fluorescent In Situ Hybridization. Applied and Environmental Microbiology. 69, pp. 1181-1186.

Mughini-Gras, L., Smid, J.H., Wagenaar, J.A., Koene, M.G.J., Havelaar, A.H., Friesema, I.H.M. et al. (2013). Increased risk for Campylobacter jejuni and C. coli infection of pet origin in dog owners and evidence for genetic association between strains causing infection in humans and their pets. Epidemiology and Infection. 141, pp. 2526-2535.

Muirhead, R.W., Collins, R.P. and Bremer, P.J. (2006). Numbers and transported state of Escherichia coli in runoff direct from fresh cowpats under simulated rainfall*. Letters in Applied Microbiology. 42, pp. 83-87.

Murphy, C., Carroll, C. and Jordan, K.N. (2006). Environmental survival mechanisms of the foodborne pathogen Campylobacter jejuni. Journal of Applied Microbiology. 100, pp. 623-632. 
Murray, C.J.L., Vos, T., Lozano, R., Naghavi, M., Flaxman, A.D., Michaud, C. et al. (2012). Disability-adjusted life years (DALYs) for 291 diseases and injuries in 21 regions, 1990-2010: a systematic analysis for the Global Burden of Disease Study 2010. Lancet (London, England). 380, pp. 2197-2223. doi: 10.1016/S0140-6736(12)61689-4.

Nam, H.M., Srinivasan, V., Murinda, S.E. and Oliver, S.P. (2005). Detection of Campylobacter jejuni in dairy farm environmental samples using SYBR green real-time polymerase chain reaction. Foodborne Pathogens and Disease. 2 , pp. 160-168.

Nayak, R., Stewart, T.M. and Nawaz, M.S. (2005). PCR identification of Campylobacter coli and Campylobacter jejuni by partial sequencing of virulence genes. Molecular and Cellular Probes. 19, pp. 187-193.

Neimann, J., Engberg, J., Møbak, K. and Wegener, H.C. (2003). A Case-Control Study of Risk Factors for Sporadic Campylobacter Infections in Denmark. Epidemiology and Infection. 130, pp. 353-366.

Nichols, G.L. (2005). Fly Transmission of Campylobacter. Emerging Infectious Diseases. 11, pp. 361-364.

Nichols, G.L., Richardson, J.F., Sheppard, S.K., Lane, C. and Sarran, C. (2012). Campylobacter epidemiology: a descriptive study reviewing 1 million cases in England and Wales between 1989 and 2011. BMJ Open. 2, pp. e001179.

Nicholson, F.A., Groves, S.J. and Chambers, B.J. (2005). Pathogen survival during livestock manure storage and following land application. Bioresource Technology. 96, pp. 135-143.

Nielsen, E.M. (2002). Occurrence and strain diversity of thermophilic campylobacters in cattle of different age groups in dairy herds. Letters in Applied Microbiology. 35, pp. 85-89.

NNDSS Annual Report Writing Group (2012). Australia's notifiable disease status, 2010: annual report of the National Notifiable Diseases Surveillance System.

Nogva, H.K., Bergh, A., Holck, A. and Rudi, K. (2000). Application of the 5 '-nuclease PCR assay in evaluation and development of methods for quantitative detection of Campylobacter jejuni. Applied and Environmental Microbiology. 66, pp. 4029-4036.

Nylen, G., Dunstan, F., Palmer, S.R., Andersson, Y., Bager, F., Cowden, J. et al. (2002). The Seasonal Distribution of Campylobacter Infection in Nine European Countries and New Zealand. Epidemiology and Infection. 128, pp. 383-390.

Obiri-Danso, K. and Jones, K. (1999). Distribution and seasonality of microbial indicators and thermophilic campylobacters in two freshwater bathing sites on the River Lune in northwest England. Journal of Applied Microbiology. 87, pp. 822-832.

Obiri-Danso, K., Paul, N. and Jones, K. (2001). The effects of UVB and temperature on the survival of natural populations and pure cultures of Campylobacter jejuni, Camp. coli, Camp. lari and urease-positive thermophilic campylobacters (UPTC) in surface waters. Journal of Applied Microbiology. 90, pp. 256-267.

Ogden, I.D., Dallas, J.F., MacRae, M., Rotariu, O., Reay, K.W., Leitch, M. et al. (2009). Campylobacter Excreted into the Environment by Animal Sources: Prevalence, Concentration Shed, and Host Association. Foodborne Pathogens and Disease. 6, pp. 1161-1170.

Oh, E., McMullen, L. and Jeon, B. (2015). Impact of oxidative stress defense on bacterial survival and morphological change in Campylobacter jejuni under aerobic conditions. Frontiers in Microbiology. 6, pp. 295.

Oliver, J.D. (2005). The viable but nonculturable state in bacteria. Journal of Microbiology. 43, pp. 93-100.

Olson, C.K., Ethelberg, S., Van Pelt, W. and Tauxe, R.V. (2008). Epidemiology of Campulobacter jejuni infections in industrialized nations. Campylobacter. 3rd, (Nachamkin, I., Szymanski, C.M. and Blaser, M.J., ed.). American Society for Microbiology. Washington, DC. pp. 9.

On, S.L.W., McCarthy, N., Miller, W.G. and Gilpin, B.J. (2008). Molecular epidemiology of Campylobacter species. Campylobacter. 3rd, (Nachamkin, I., Szymanski, C.M. and Blaser, M.J., ed.). American Society for MIcrobiology. Washington, DC. 
Oporto, B., Esteban, J.I., Aduriz, G., Juste, R.A. and Hurtado, A. (2007). Prevalence and strain diversity of thermophilic campylobacters in cattle, sheep and swine farms. Journal of Applied Microbiology. 103, pp. 977-984.

Park, C.E. and Sanders, G.W. (1992). Occurrence of thermotolerant campylobacters in fresh vegetables sold at farmers' outdoor markets and supermarkets. Canadian Journal of Microbiology. 38 (4), pp. 313-316.

Park, S.H., Hanning, I., Jarquin, R., Moore, P., Donoghue, D.J., Donoghue, A.M. et al. (2011). Multiplex PCR assay for the detection and quantification of Campylobacter spp., Escherichia coli 0157:H7, and Salmonella serotypes in water samples. FEMS Microbiology Letters. 316, pp. 7-15.

Park, S.F. (2002). The physiology of Campylobacter species and its relevance to their role as foodborne pathogens. International Journal of Food Microbiology. 74, pp. 177-188.

Patrone, V., Campana, R., Vallorani, L., Dominici, S., Federici, S., Casadei, L. et al. (2013). CadF expression in Campylobacter jejuni strains incubated under low-temperature water microcosm conditions which induce the viable but non-culturable (VBNC) state. Antonie van Leeuwenhoek. 103, pp. 979-988.

Pitkänen, T., Miettinen, I.T., Nakari, U.M., Takkinen, J., Nieminen, K., Siitonen, A. et al. (2008). Faecal contamination of a municipal drinking water distribution system in association with Campylobacter jejuni infections. Journal of Water and Health. 6, pp. 365-376.

Pitkänen, T. (2013). Review of Campylobacter spp. in drinking and environmental waters. Journal of Microbiological Methods. 95, pp. 39-47.

Pitkänen, T., Juselius, T., Isomäki, E., Miettinen, T.I., Valve, M., Kivimäki, A.-.L. et al. (2015). Drinking Water Quality and Occurrence of Giardia in Finnish Small Groundwater Supplies. Resources. 4,.

Platts-Mills, J.A., Babji, S., Bodhidatta, L., Gratz, J., Haque, R., Havt, A. et al. (2015). Pathogen-specific burdens of community diarrhoea in developing countries: a multisite birth cohort study (MAL-ED). The Lancet Global health. 3, pp. e564-e575.

Pradhan, A.K., Van Kessel, J.S., Karns, J.S., Wolfgang, D.R., Hovingh, E., Nelen, K.A. et al. (2009). Dynamics of endemic infectious diseases of animal and human importance on three dairy herds in the northeastern United States. Journal of Dairy Science. 92, pp. 1811-1825.

Pradhan, S.K., Kauppinen, A., Martikainen, K., Pitkänen, T., Kusnetsov, J., Miettinen, I.T. et al. (2013). Microbial reduction in wastewater treatment using $\mathrm{Fe}(3+)$ and $\mathrm{Al}(3+)$ coagulants and PAA disinfectant. Journal of Water and Health. 11, pp. 581-589.

Rechenburg, A. and Kistemann, T. (2009). Sewage effluent as a source of Campylobacter sp. in a surface water catchment. International Journal of Environmental Health Research. 19, pp. 239-249.

Revez, J., Llarena, A.K., Schott, T., Kuusi, M., Hakkinen, M., Kivisto, R. et al. (2014). Genome analysis of Campylobacter jejuni strains isolated from a waterborne outbreak. BMC Genomics. 15, pp. 768.

Robinson, D.A. (1981). Infective dose of Campylobacter jejuni in milk. BMJ. 282, pp. 1584.

Rodríguez, S. and Araujo, R. (2012). Effect of environmental parameters on the inactivation of the waterborne pathogen Campylobacter in a Mediterranean river. Journal of Water and Health. 10 (1), pp. 100-107.

Rodríguez, S. and Araujo, R. (2010). Occurrence of thermotolerant Campylobacter species in surface waters of a Mediterranean area and in its prevailing pollution sources. Journal of Applied Microbiology. 109, pp. 1027-1034.

Rollins, D.M. and Colwell, R.R. (1986). Viable but nonculturable stage of Campylobacter jejuni and its role in survival in the natural aquatic environment. Applied and Environmental Microbiology. 52, pp. 531-538.

Rosef, O., Rettedal, G. and Lågeide, L. (2001). Thermophilic campylobacters in surface water: a potential risk of campylobacteriosis. International Journal of Environmental Health Research. 11, pp. 321-327. 
Ross, C.M. and Donnison, A.M. (2006). Campylobacter jejuni inactivation in New Zealand soils. Journal of Applied Microbiology. 101, pp. 1188-1197.

Sahlström, L., Aspan, A., Bagge, E., Tham, M.L.D. and Albihn, A. (2004). Bacterial pathogen incidences in sludge from Swedish sewage treatment plants. Water Research. 38, pp. 1989-1994.

Sails, A.D., Fox, A.J., Bolton, F.J., Wareing, D.R.A. and Greenway, D.L.A. (2003). A Real-Time PCR Assay for the Detection of Campylobacter jejuni in Foods after Enrichment Culture. Applied and Environmental Microbiology. 69, pp. 1383-1390.

Sari Kovats, R., Edwards, S.J., Charron, D., Cowden, J., De Souza, R.M., Ebi, K.L. et al. (2005). Climate variability and campylobacter infection: an international study. International Journal of Biometeorology. 49, pp. 207-214.

Savill, M.G., Hudson, J.A., Ball, A., Klena, J.D., Scholes, P., Whyte, R.J. et al. (2001). Enumeration of Campylobacter in New Zealand recreational and drinking waters. Journal of Applied Microbiology. 91, pp. 38-46.

Scallan, E., Hoekstra, R.M., Mahon, B.E., Jones, T.F. and Griffin, P.M. (2015). An assessment of the human health impact of seven leading foodborne pathogens in the United States using disability adjusted life years. Epidemiology and Infection. 143, pp. 2795-2804.

Schonberg-Norio, D., Takkinen, J., Hanninen, M.L., Katila, M.L., Kaukoranta, S.S., Mattila, L. et al. (2004). Swimming and Campylobacter infections. Emerging Infectious Diseases. 10, pp. 1474-1477.

Sheludchenko, M., Padovan, A., Katouli, M. and Stratton, H. (2016). Removal of Fecal Indicators, Pathogenic Bacteria, Adenovirus, Cryptosporidium and Giardia (oo)cysts in Waste Stabilization Ponds in Northern and Eastern Australia. International Journal of Environmental Research and Public Health. 13,.

Sheppard, S.K., Dallas, J.F., Strachan, N.J.C., MacRae, M., McCarthy, N.D., Wilson, D.J. et al. (2009). Campylobacter Genotyping to Determine the Source of Human Infection. Clinical Infectious Diseases. 48, pp. 1072-1078.

Simmons, C.W., Guo, H., Claypool, J.T., Marshall, M.N., Perano, K.M., Stapleton, J.J. et al. (2013). Managing compost stability and amendment to soil to enhance soil heating during soil solarization. Waste Management. 33, pp. 1090-1096.

Sinton, L., Hall, C. and Braithwaite, R. (2007). Sunlight inactivation of Campylobacter jejuni and Salmonella enterica, compared with Escherichia coli, in seawater and river water. Journal of Water and Health. 5, pp. 357-365.

Skirrow, M.B. (1977). Campylobacter enteritis: a "new" disease. British Medical Journal. 2, pp. 9-11.

Skirrow, M.B. and Blaser, M.J. (2000). Clinical aspects of Campylobacter infection. Campylobacter. 2 ed. (Nachamkin, I. and Blaser, M.J., ed.). ASM Press. Washington DC. pp. 69.

Snelling, W.J., McKenna, J.P., Lecky, D.M. and Dooley, J.S.G. (2005). Survival of Campylobacter jejuni in waterborne protozoa. Applied and Environmental Microbiology. 71, pp. 5560-5571.

Stampi, S., De Luca, G., Varoli, O. and Zanetti, F. (1999). Occurrence, removal and seasonal variation of thermophilic campylobacters and Arcobacter in sewage sludge. Zentralblatt für Hygiene und Umweltmedizin. 202(1), pp. 19-27.

Stampi, S., Varoli, O., De Luca, G. and Zanetti, F. (1992). Occurrence, removal and seasonal variation of thermophilic campylobacters in a sewage treatment plant in Italy. Zentralblatt fur Hygiene und Umweltmedizin = International Journal of Hygiene and Environmental Medicine. 193, pp. 199-210.

Stampi, S., Varoli, O., Zanetti, F. and De Luca, G. (1993). Arcobacter cryaerophilus and thermophilic campylobacters in a sewage treatment plant in Italy: two secondary treatments compared. Epidemiology and Infection. 110, pp. 633-639.

Stelzer, W. and Jacob, J. (1991). A Study of Campylobacter in Sewage, Sewage Sludge and in River Water. Water Science and Technology. 24, pp. 117.

Sterk, A., Schijven, J., Husman, A.M. de Roda and de Nijs, T. (2016). Effect of climate change on runoff of Campylobacter and Cryptosporidium from land to surface water. Water Research. 95, pp. 90-102. 
Studahl, A. and Andersson, Y. (2000). Risk factors for indigenous campylobacter infection: a Swedish case-control study. Epidemiology and Infection. 125, pp. 269-275.

Svensson, S.L., Frirdich, E. and Gaynor, E.C. (2008). Survival strategies of Campylobacter jejuni: Stress responses, the viable but nonculturable state and biofilms. Campylobacter. 3rd, (Nachamkin, I., Szymanski, C.M. and Blaser, M.J., ed.). Americal Society for Microbiology. Washington, DC.

Tambalo, D.D., Boa, T., Aryal, B. and Yost, C.K. (2016). Temporal variation in the prevalence and species richness of Campylobacter spp. in a prairie watershed impacted by urban and agricultural mixed inputs. Canadian Journal of Microbiology. 62, pp. 402-410. doi: 10.1139/cjm-2015-0710 [doi].

Tam, C.C., O'Brien, S.J., Petersen, I., Islam, A., Hayward, A. and Rodrigues, L.C. (2007). Guillain-Barré Syndrome and Preceding Infection with Campylobacter, Influenza and Epstein-Barr Virus in the General Practice Research Database. PLOS ONE. 2, pp. 1-6.

Tam, C.C., O’Brien, S.J., Tompkins, D.S., Bolton, F.J., Berry, L., Dodds, J. et al. (2012). Changes in Causes of Acute Gastroenteritis in the United Kingdom Over 15 Years: Microbiologic Findings From 2 Prospective, Population-Based Studies of Infectious Intestinal Disease. Clinical Infectious Diseases. 54, pp. 1275-1286.

Taylor, D.N., Perlman, D.M., Echeverria, P.D., Lexomboon, U. and Blaser, M.J. (1993). Campylobacter Immunity and Quantitative Excretion Rates in Thai Children. Journal of Infectious Diseases. 168, pp. 754-758.

Tholozan, J.L., Cappelier, J.M., Tissier, J.P., Delattre, G. and Federighi, M. (1999). Physiological characterization of viablebut-nonculturable Campylobacter jejuni cells. Applied and Environmental Microbiology. 65, pp. 1110-1116.

Thomas, C., Gibson, H., Hill, D.J. and Mabey, M. (1999). Campylobacter epidemiology: an aquatic perspective. Journal of Applied Microbiology. 85, pp. 168S-177S.

Thomas, C., Hill, D.J. and Mabey, M. (1999). Evaluation of the effect of temperature and nutrients on the survival of Campylobacter spp. in water microcosms. Journal of Applied Microbiology. 86, pp. 1024-1032.

Thomas, M.K., Murray, R., Flockhart, L., Pintar, K., Pollari, F., Fazil, A. et al. (2013). Estimates of the Burden of Foodborne Illness in Canada for 30 Specified Pathogens and Unspecified Agents, Circa 2006. Foodborne Pathogens and Disease. 10, pp. 639-648.

Totten, P.A., Patton, C.M., Tenover, F.C., Barrett, T.J., Stamm, W.E., Steigerwalt, A.G. et al. (1987). Prevalence and characterization of hippurate-negative Campylobacter jejuni in King County, Washington. Journal of Clinical Microbiology. 25, pp. 1747-1752.

Tourlousse, D.M., Ahmad, F., Stedtfeld, R.D., Seyrig, G., Tiedje, J.M. and Hashsham, S.A. (2012). A polymer microfluidic chip for quantitative detection of multiple water- and foodborne pathogens using real-time fluorogenic loop-mediated isothermal amplification. Biomedical Microdevices. 14, pp. 769-778.

Townes, J.M. (2010). Reactive Arthritis after Enteric Infections in the United States: The Problem of Definition. Clinical Infectious Diseases. 50, pp. 247-254.

Ugarte-Ruiz, M., Gómez-Barrero, S., Porrero, M.C., Álvarez, J., García, M., Comerón, M.C. et al. (2012). Evaluation of four protocols for the detection and isolation of thermophilic Campylobacter from different matrices. Journal of Applied Microbiology. 113, pp. 200-208.

Ugarte-Ruiz, M., Florez-Cuadrado, D., Wassenaar, T.M., Porrero, M.C. and Domínguez, L. (2015). Method Comparison for Enhanced Recovery, Isolation and Qualitative Detection of C. jejuni and C. coli from Wastewater Effluent Samples. International Journal of Environmental Research and Public Health. 12, pp. 2749.

Vaerewijck, M.J.M., Baré, J., Lambrecht, E., Sabbe, K. and Houf, K. (2014). Interactions of Foodborne Pathogens with Freeliving Protozoa: Potential Consequences for Food Safety. Comprehensive Reviews in Food Science and Food Safety. 13, pp. 924-944. 
VanDyke, M.I., Morton, V.K., McLellan, N.L. and Huck, P.M. (2010). The occurrence of Campylobacter in river water and waterfowl within a watershed in southern Ontario, Canada. Journal of Applied Microbiology. 109, pp. 1053-1066.

Vereen, E., Lowrance, R.R., Cole, D.J. and Lipp, E.K. (2007). Distribution and Ecology of Campylobacters in Coastal Plain Streams (Georgia, United States of America). Applied and Environmental Microbiology. 73, pp. 1395-1403.

Wéry, N., Lhoutellier, C., Ducray, F., Delgenès, J.P. and Godon, J.J. (2008). Behaviour of pathogenic and indicator bacteria during urban wastewater treatment and sludge composting, as revealed by quantitative PCR. Water Research. 42, pp. 53-62.

Waage, A.S., Vardund, T., Lund, V. and Kapperud, G. (1999). Detection of small numbers of Campylobacter jejuni and Campylobacter coli cells in environmental water, sewage, and food samples by a seminested PCR assay. Applied and Environmental Microbiology. 65, pp. 1636-1643.

Wagenaar, J.A., Newell, D.G., Kalupahana, R.S. and Mughini-Gras, L. (2015). Campylobacter: Animal Reservoirs, Human Infections, and Options for Control. Zoonoses - Infections Affecting Humans and Animals: Focus on Public Health Aspects. (Sing, A., ed.). Springer Netherlands. Dordrecht. pp. 159-177.

Wagner, A.O., Malin, C., Gstraunthaler, G. and Illmer, P. (2009). Survival of selected pathogens in diluted sludge of a thermophilic waste treatment plant and in NaCl-solution under aerobic and anaerobic conditions. Waste Management. 29, pp. 425-429.

Wassenaar, T.M. and Newell, D.G. (2000). Genotyping of Campylobacter spp. Applied and Environmental Microbiology. 66, pp. 1-9.

Wesley, I.V., Wells, S.J., Harmon, K.M., Green, A., Schroeder-Tucker, L., Glover, M. et al. (2000). Fecal Shedding of Campylobacter and Arcobacter spp. in Dairy Cattle. Applied and Environmental Microbiology. 66, pp. $1994-2000$.

Whiley, H., van den Akker, B., Giglio, S. and Bentham, R. (2013). The Role of Environmental Reservoirs in Human Campylobacteriosis. International Journal of Environmental Research and Public Health. 10, pp. 5886.

Wilson, I.G. and Moore, J.E. (1996). Presence of Salmonella spp. and Campylobacter spp. in shellfish. Epidemiology and Infection. 116, pp. 147-153.

Yang, C.B., Jiang, Y., Huang, K.H., Zhu, C.Q. and Yin, Y.L. (2003). Application of real-time PCR for quantitative detection of Campylobacter jejuni in poultry, milk and environmental water. FEMS Immunology and Medical Microbiology. 38, pp. 265-271. 